\title{
Sept $\frac{7}{8}$ \\ 17-20 害
}

\section{International Congress on \\ Biorefineries and Renewable}

Energies Supported by ICT:

Business opportunities based on

technologies and innovation

\section{rUt:}
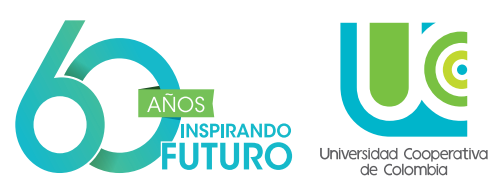

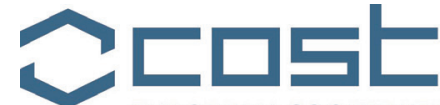

ROYAL

ACADEMY OF ENGINEERING 


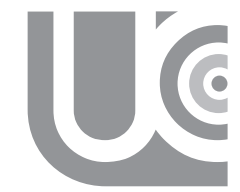

Universidad Cooperativa de Colombia
I International Congress on Biorefineries and Renewable Energies Supported by ICT:

Business opportunities based on technologies and innovation

Date: 17 - 20 September 2018

Place: Universidad Cooperativa de Colombia

Headquarters Medellín, Colombia

doi: https://doi.org/10.16925/greylit.2048

\section{EDITORIAL BOARD}

Ramón Fernando Colmenares Quintero, Professor Dr.

$\mathrm{PhD}$ in Aerospace Engineering. Universidad

Cooperativa de Colombia
Gina Paola Maestre, PhD

$\mathrm{PhD}$ in Systems Engineering. Universidad

Cooperativa de Colombia

ORGANISING COMMITTEE

Colombia

Ramón Fernando Colmenares Quintero, Professor Dr.

Gina Paola Maestre, $\mathrm{PhD}$

Diana Caicedo, $\mathrm{PhD}$

Daniel Delgado, PhD

Flavio Augusto Pinto Siabatto, PhD

Laura Castillo, Miss

Universidad Cooperativa de Colombia
Carlos Eduardo Gil de Los Ríos, Frigate Captain Jymmy Saravia Arenas, Mr.

Karen Patricia Domínguez, Miss. Mónica Ruiz Pianeta, Miss.

Gabriela Guadalupe Salas Berrocal, Miss. Science and Technology Corporation for Naval, Maritime and Riverine Industry Development - Cotecmar

Edgar Fernando Castillo Monroy, PhD Instituto Colombiano del Petróleo - Ecopetrol

Argiro Ramírez, Mr.

Colciencias

United Kingdom

Natalia Rojas, Miss.

Sandy Kerr, PhD

Aquatera Ltd.

Heriot-Watt University 


\section{SCIENTIFIC COMMITTEE}

Rajender (Raj) Varma, Professor Dr.

United States of America

us Environmental Protection Agency

Janka Dibdiakova, PhD

Norway

Norwegian Institute of Bioeconomy Research (NIBIO)

Rafael Luque Álvarez de Sotomayor, Professor Dr. Spain

Universidad de Córdoba

Juan Carlos Colmenares Quintero, Professor Dr. Poland

Institute of Physical Chemistry of the

Polish Academy of Sciences

Alberto Coz Fernández, Professor Dr. Spain

Universidad de Cantabria

Klaus Johannes Niemelä, $\mathrm{PhD}$

Finland

VTT Technical Research Centre of Finland Ltd.

Ondřej Mašek, $\mathrm{PhD}$

United Kingdom

University of Edinburgh, UK Biochar

Research Centre (UKBRC)

Ramón Fernando Colmenares Quintero, Professor Dr.

Colombia

Universidad Cooperativa de Colombia

Konstantinos Triantafyllidis, Professor Dr. Greece

Aristotle University of Thessaloniki

Kim Stansfield, Professor Dr.

United Kingdom

Warwick University, Warwick Manufacturing Group (WMG)

Christophe Len, Professor Dr.

France

Chimie ParisTech

Damian Kasperczyk, Mr.

Poland

Ekoinwentyka sp. Z o.o.
Edgar Fernando Castillo Monroy, PhD

Colombia

Instituto Colombiano del Petróleo - Ecopetrol

Fernando Macho Hernantes, Mr. Spain

Servicios Empresariales Comunitarios, S. L. (SEC)

Daniel Portnoy, $\mathrm{PhD}$ Israel

Consultech Colombia SAS IL / Consultech Israel

Natalia Rojas, Miss

United Kingdom

Aquatera Ltd.

Argiro de J. Ramírez A., Mr.

Colombia

Colciencias

Gina Paola Maestre, $\mathrm{PhD}$

Colombia

Universidad Cooperativa de Colombia

Diana Caicedo, PhD Colombia

Universidad Cooperativa de Colombia

Daniel Delgado, $\mathrm{PhD}$

Colombia

Universidad Cooperativa de Colombia

Flavio Augusto Pinto Siabatto, PhD

Colombia

Universidad Cooperativa de Colombia

Adriana Villegas, $\mathrm{PhD}$

Colombia

Universidad Cooperativa de Colombia

Carol Lin, Professor Dr. China

City University of Hong Kong

Rafael Popper, Professor Dr. Finland

VTT Technical Research Centre of Finland Ltd.

\section{Awards}

The best summaries will be considered for a special issue in:

$\star$ cogent

engineering
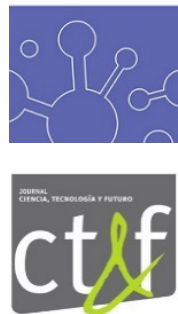

Cogent Engineering Journal (indexed in ISI-Scopus). Publisher: Taylor and Francis, United Kingdom. These articles must follow the journal's editorial guidelines.

CT \& Journal - Ciencia, Tecnología y Futuro (indexed in IsI-Scopus), Journal of Technology, Science and Future. Ecopetrol S.A. Edited by the Instituto Colombiano del Petróleo (ICP). 


\section{Content}

Introduction

Agenda

\section{Keynote Speaker Abstracts}

Biomass Boon: Carbonaceous Magnetic Materials in Sustainable

Chemical Syntheses

Rajender S. Varma

Textile Waste Recycling by Biological Methods

Carol S. K. Lin, Xiaotong Li, Chenyu Du, Shao-Yuan Leu, Nattha Pensupa

Clean processes - Biodegradation of waste gases in a Compact

Trickle Bed Bioreactor as an Economically Attractive way of Waste

Gas Treatment in Paint Industry

Damian Kasperczyk, Ramón F. Colmenares-Quintero, K. Urbaniec,

K. Barbusiński

Examples of Recent Global Trends in Wood-Based Biorefining

Klaus Niemelä

Selective Fractionation and Conversion of Biomass via

Thermochemical and (Bio)Catalytic Processes

Konstantinos S. Triantafyllidis

Benign By-Design Processes for Sustainable Biomass/Waste Valorisation

Rafael Luque

Biochar from Sustainable Resources and its Environmental Applications

Ondrej Mašek, W. Buss, Julian Pietrzyk, Mingyu Hu, Jan Mumme, Andrew Free

Using Modern QFD System's Thinking Methods

Kim E. Stansfield, Mike Colechin, Glenn H. Mazur,

Ramón F. Colmenares-Quintero

Microbial Biogas Production from Hydrolysis Lignin: Insight into

Lignin Structural Changes

Daniel G. Mulat, Janka Dibdiakova, Svein J. Horn

Glycerol, a By-product of Biodiesel Production for

Value-Added Chemicals

Christophe Len

Valorisation of Biomass through Low-Temperature Hydrothermal

Transformations assisted by Photocatalysis

Juan C. Colmenares, Vaishakh Nair

Integration of Biomass Products in a Traditional Oil and Gas Industry.

The case of Ecopetrol

Edgar F. Castillo

Unlocking the Bioeconomy Potential of Latin America. Common

Framework for the Assessment and Management of Sustainable

Innovations (CASI-F): Methodology for Future Research on Sustainability

Rafael Popper, Monika Popper, Guillermo Velasco

Case Study of R\&D\&I in a Pulp Mill to be integrated as a Forest Biorefinery

Alberto Coz, Tamara Llano, Cristina Rueda, Carlos Arce, Gema Ruiz

Chatbots, Artificial Intelligence, Natural Language processing and 
Aquatic Renewable Energy Potential in Colombia

Natalia Rojas, Ramón F. Colmenares-Quintero

Renewable Energy Solutions for Off-grid Zones

Ramón F. Colmenares-Quintero, Luis F. Latorre-Noguera, Natalia Rojas,

Karl Kolmsee, Gina Maestre-Góngora

Strategic Plan Advances of the National Marine Sciences and

Hydrobiological Resources Program

Argiro de J. Ramírez

\section{Short Presentations' Abstracts}

Use of Autonomous Drones for Monitoring, Surveillance and Security

Daniel Portnoy

Valuation of Coffee Pulp applying the Biorefinery concept

to produce High Value-Added Phytochemicals, Syngas and Methanol

Carlos E. Aristizábal, Andrés F. Vargas, Pedro N. Alvarado

Pyrolytic Kinetic Studies, Energetic Potential and Gasification

Simulation Process of the Green Microalga Botryococcus Braunii

Andrés A. Arbeláez, Néstor D. Giraldo, Juan F. Bayer, Lucía Atehortúa

Fique as Thermal Insulator. Thermal Characterisation of Fique Fibres

Gabriel F. García Sánchez, Rolando E. Guzmán, Adriana M. Restrepo,

Emil Hernández

The Potential of Methane Production using Aged Landfill Waste in

Developing Countries: A Case Study in Colombia

Diana M. Caicedo-Concha; John J. Sandoval-Cobo,

Ramón F. Colmenares-Quintero, Luis T. Marmolejo-Rebellón,

Patricia Lozada, Sonia Heaven

Public Policies on Renewable Energies at an International Level:

A Study of Systematic Mapping

Jimena Cardona-Cuervo, Ramón F. Colmenares-Quintero,

Gina Maestre-Góngora

Identification of Methodologies in the Teaching-Learning of

Renewable Energies

A. Orozco, K. Benítez, J. Montes, Diana M. Caicedo-Concha,

Dario Quiroga-Parra, Ramón F. Colmenares-Quintero

Review of the Technological Solutions for the Implementation

of Clean Energies in Ships and their Prospective Integration to a

New Generation of Colombian Vessels

Mónica Ruiz-Pianeta, Gabriela Salas-Berrocal, Karen Domínguez-Martínez

Methodology for Characterisation of the Vitoyó Village

Community -Indigenous Reservation of Jambaló -Cauca

Juliana Benavides, Ramón F. Colmenares-Quintero, Sergio Barbosa,

Gina Maestre-Góngora

Software Development of Carbon and Water Footprint in

Coffee Production

Ferley Medina, Irlesa I. Sánchez, Jaime M. Cabrera, Jhon F. Ortiz,

Andrés F. Ortigoza

Life Cycle Assessment of Msw Landfill Management Strategies

in Colombia: Case Study

Paola A. Ramírez-Rodríguez, John J. Sandoval-Cobo,

Ramón F. Colmenares-Quintero, Diana M. Caicedo-Concha 
Incidence of Photovoltaic Cell Temperature in Energy Conversion

for Silicon Panels

Leiny Ordoñez, Lisbeth Martínez, Ángela Aguirre, Diego Hernández

A Comprehensive Solution Approach to the Sustainability Problem

of Photovoltaic Systems: The Bolivian Case

Arturo Dávalos Yoshida, Richard Gil Herrera

CFD Analysis of a Subsonic Air-to-Air Ejector: Influence of the Mixing

Tube's Length on its Performance

Diana I. González-Arango, Jorge A. Sierra, Diego A. Hincapié-Zuluaga

Long-Term Energy Storage Challenges for Solar Lighting Applications

in Desert Environments

Thomas Samuel, Raphael Baillot

Bold Incidence of the Geometry in Air Demand of Free Surface

Discharge Conduits using CDF

Mateo Del Gallego, Jorge Sierra, Diego A. Hincapié

Design of a Wind Rotor for a Wind Pump

Fabián Solano, Sandra Cuervo-Andrade

Design of a Photovoltaic System for the Coffee Drying Process

Irlesa S Sánchez, Carlos Castro, Jaime Cabrera, Ferley Medina, Cristian Sterling,

Santiago Yunda

CFD Validation for the Design Methodology of a Cross-Flow Michell

Banki Turbine

Steven Galvis-Holguín, Mateo Del Gallego-Rico, Daniel Giraldo-Taborda,

Jorge Andrés Sierra-Del Rio, Daniel Sanín-Villa

Aerodynamic Performance Evaluation of a NACA 4415 Profile by means

of Computational Fluid Dynamics

Juan Diego Betancur, Juan Gonzalo Ardila

Study in Thermal Photovoltaic Panels Cooled by Heat Sinks modelled by Computational Fluid Dynamics

Yustin Roman, Jorge Sierra, Diego Hincapié

Central Location Optimal Distributed Generation to Minimize Effects

of Harmonics in Power Distribution Networks: Dominican Republic

Case Study

Manuel A. Landron, Richard Gil Herrera

Optimal Equalization of Distributed Energy Storage Systems in

a Microgrid

Nelson L. Díaz, Adriana C. Luna

Reference Model for Smart Technologies Management based on

National Science and Innovation Policy for Sustainable

Development - Colombia, Agenda 2030

Gina Maestre-Góngora, Ramón F. Colmenares-Quintero

Termohaline Characterization of the Gulf of Urabá Central Region,

from the Atrato River Discharge

Juan C. Guevara Aguirre, Luis A. Velásquez Ortega, Vladimir G. Toro,

Reginaldo Durazo Arvizu

ICT and its Incidence in the Productive Innovation of Renewable Energies

Dario J. Quiroga-Parra, Ramón F. Colmenares-Quintero, Gina Maestre-Góngora 
Technological Strategy for the Installation of an Energy Solution for the Catatumbo Region

Alfredo Bohórquez, Torcoroma Velázques, Hugo F.Castro

Renewable Energy Actions in the Coffee Region of

Caicedonia - Valle del Cauca Department

Jhon E. Cerón

\section{Training course}

Training Course on Aerospace Propulsion, Power, and Energy Invited: Daniel Portnoy 
$\mathrm{E}$ urope has set a solid path in the quest for an environmentally friendly development, and as of today, provides a great example and model for the rest of the world in terms of policymaking and responsible use of natural resources. In Colombia, the government recognizes that there are resources in its territory with potential to supply clean energy to the communities most in need, particularly to the rural and Non-Interconnected Zones (NIZ). As mentioned in the Law 1715 of 2014: "the State will develop strategies for the use of renewable resources for sustainable economic development, reduction of greenhouse gas emissions and energy supply security". Colombia has a rich endowment of resources for alternative energies. Its location provides the country with high solar radiation, winds of medium to high speeds $(80 \mathrm{~m}$ high in La Guajira) and energy potentials in the order of 450,000 TJ per year in biomass waste. Altogether these represent a varied compendium of alternatives that other countries at different latitudes may not benefit from. Colombia needs to benefit from these aforementioned unexploited resources due to cost reduction trends brought by alternative energies, validated technologies for the adequate use of resources; and because of the stress caused by climate change on the country's electricity supply, and its dependence on water bodies with relatively high end-user rates.

The Universidad Cooperativa de Colombia (UCC) has offices in 18 cities, a considerable portion of the country's territory and is thus a key player in the transfer of knowledge and technology. International cooperation with the cosT network (European Cooperation in Science and Technology) has helped financially to carry out research and innovation projects in various topics. Currently, the UCC is part of the FP1306 Action under the project entitled "Valorisation of Lignocellulosic Biomass Side Streams for Sustainable Production of Chemicals, Materials and Fuels using Technologies with Low Environmental Impact". This action aims to develop a solid European multidisciplinary network able to provide a range of innovative alternatives for the transformation and valorisation of lignocellulosic residues into chemicals, fuels and materials by making use of environmentally sound protocols consisting of pre-treatment/fractionation and conversion to valuable end products.

The alliance between UCC, COST Network, UK Researcher Links and ELAN (European and Latin American Technology based Business Network), targets the formulation and execution of energy projects supported by smart grids, research and academic capacity building. However, despite the strength of the alliance, a gap persists regarding the use and appropriation of these technologies in national business, government and academic sectors in terms of knowledge generation and transfer on biorefineries, and alternative and renewable energies based on ICTs. For this reason, the first International Congress on Biorefineries and Renewable Energies Supported by ICTs (вRESICT) seeks to identify and create alliance opportunities and collaborative work between the different stakeholders of the technological innovation sector.

Keywords: biorefineries, renewable energy, alternative energy, sustainable development goals, ICT, bioenergy, smart systems 


\section{Target audiences}

Academic researchers, industry and government offices related to renewable energy, biorefineries and ICTS.

\section{Objective}

Identify solutions based on the capabilities and technologies developed by universities, industry or national and international governments, for the country's and the global energy challenges, with special attention to those framed in the United Nations' sustainable development goals (sdgs).

\section{Agenda}

\section{Monday, September 17}

Meeting: Science, Technology and Innovation

\section{7:00}

\section{Registration}

8:30 Welcoming: Dr. Maritza Rondón Rangel, Rector of the Universidad Cooperativa de Colombia, Professor Dr. Rafael Luque, Professor Dr. Kostantinos Triantafyllidis, President/ Vice-president of the FP1306 CosT Action, European Cooperation in Science \& Technology

9:00 KNs-1 Rajender S. Varma, "Biomass Boon: Carbonaceous Magnetic Materials in Sustainable Chemical Syntheses"

9:30 Valuation of Coffee Pulp applying the Biorefinery concept to Produce High Value-Added Phytochemicals, Syngas and Methanol", Carlos E. Aristizábal, Andrés F. Vargas, Pedro N. Alvarado

\section{9:45 Coffee Break}

10:15 KNS- 2 Carol Lin, “Transforming Food and Textile Wastes to High Value-Added Products"
10:45 "Pyrolytic Kinetic Studies, Energetic Potential and Gasification Simulation Process of the Green Microalga Botryococcus Braunii", Andrés A. Arbeláez, Néstor D. Giraldo, Juan F. Bayer, Lucía Atehortúa

11:00 KNs-3 Damian Kasperczyk, "Clean Processes - Biodegradation of Waste Gases in a Compact Trickle Bed Bioreactor (Ствв) as an Economically Attractive Alternative for Waste Treatment"

11:30 "Fique as Thermal Insulator. Thermal Characterization of Fique Fibres", Gabriel F. García-Sánchez, Rolando E. Guzmán, Adriana M. Restrepo, Emil Hernández

11:45 "The Planet Needs a Green Revolution: Solar Energy, an Overview from a Global to a Local Perspective", Faber Díaz, Ambiente Soluciones - LED Solar Energy

12:00 Conclusions

\section{2:15 Lunch}

13:30 KNS-4 Klaus Niemelä, "Examples of Recent Trends in Wood-Based Bio Refining R\&D in Europe"

14:00 "The Potential of Methane Production using Aged Landfill Waste in Developing Countries: A Case Study in Colombia", Diana M. Caicedo-Concha

14:15 "Public Policies on Renewable Energies at an International Level: A Study of Systematic Mapping", Jimena Cardona

14:30 KNS-5 Konstantinos Triantafyllidis, "Selective Fractionation and Conversion of Biomass via Thermochemical and (Bio)Catalytic Processes"

15:00 "Identification of Methodologies in the Teaching-Learning of Renewable Energies", Alexander Orozco, Kevin Benítez, Juan Carlos Montes, Diana M. Caicedo-Concha

15:15 "Review of the Technological Solutions for the Implementation 
of Clean Energies in Ships and their Prospective Integration to a New Generation of Colombian Vessels", Mónica Ruiz-Pianeta, Gabriela SalasBerrocal, Karen Domínguez Martínez

\section{5:30 Coffee Break}

16:00 KNs-6 Rafael Luque, "Benign-ByDesign Processes for Sustainable Biomass/Waste Valorisation"

16:30 "Methodology for Characterisation of the Vitoyó Village Community -Indigenous Reservation of Jambaló -Cauca", Juliana Benavides

16:45 "Software Development of Carbon and Water Footprint in Coffee Production", Ferley Medina, Irlesa I. Sánchez, Jaime M. Cabrera, Jhon F. Ortiz, Andrés Ortigoza

17:00 Conclusions

Tuesday, September 18 Meeting: Science, Technology and Innovation

9:00 KNs-7 Ondřej Mašek, "Biochar from Sustainable Resources and its Environmental Applications"

9:30 KNs-8 Kim Stansfield, "Soft Systems Method Integration with Sustainable Energy Systems Development using ISO16355 for QFD"

\section{0:00 Coffee Break}

10:30 KNS-9 Janka Dibdiakova, "Microbial Biogas Production from Hydrolysis Lignin: Insight for Lignin Structural Changes"

11:00 "Life Cycle Assessment of Mws Landfill Management Strategies in Colombia: Case Study", Diana M. Caicedo-Concha

11:15 KNS-10 Christophe Len, "Glycerol, a By-product of Biodiesel Production for Value-Added Chemicals"

11:45 "Incidence of Photovoltaic Cell Temperature in Energy Conversion for Silicon Panels", Leiny Ordóñez,
Lisbeth Martínez, Ángela Aguirre, Diego Hernández

12:00 Conclusions

\section{2:15 Lunch}

13:30 KNS-11 Juan Carlos Colmenares Quintero, "Valorisation Of Biomass Through Low-Temperature Hydrothermal Transformations Assisted By Photocatalysis"

14:00 "A Comprehensive Solution Approach to the Sustainability Problem of Photovoltaic Systems: The Bolivian Case", Adolfo Arturo, Richard Gil-Herrera

14:15 "CFD Analysis of a Subsonic Air-to-Air Ejector: Influence of the Mixing Tube's Length on its Performance", Diana I. González-Arango, Jorge A. Sierra, Diego A. Hincapié-Zuluaga

14:30 KNs-12 Edgar Castillo, "Integration of Biomass Products in a Traditional Oil and Gas Industry. The case of Ecopetrol"

15:00 "Long-Term Energy Storage Challenges for Solar Lighting Applications in Desert Environments", Thomas Samuel, Raphael Baillot

15:15 "Bold Incidence of the Geometry in Air Demand of Free Surface Discharge Conduits using CDF", Mateo Del Gallego Rico, Jorge Sierra Del Rio, Diego A. Hincapié

\section{5:30 Coffee Break}

16:00 "Design of a Wind Rotor for a Wind Pump" Fabián Solano, Sandra Cuervo-Andrade

16:15 "Design of a Photovoltaic System for the Coffee Drying Process", Irlesa Sánchez, Carlos Castro, Jaime Cabrera, Ferley Medina, Cristian Sterling, Santiago Yunda.

16:30 KNs-13 Rafael Popper, "Unlocking the Bioeconomy Potential of Latin America: VTT's Foresight Experience in Uruguay"

17:00 Conclusions 
Wednesday, September 19

Meeting: Science, Technology

and Innovation

9:00 KNs-14 Alberto Coz, "Case Study of R\&D\&I in a Pulp Mill to be Integrated as a Forest Biorefinery"

9:30 "CFD Validation for the Design Methodology of a Cross-Flow Michell Banki Turbine", Steven Galvis-Holguin, Mateo Del GallegoRico, Daniel Giraldo-Taborda, Jorge Andrés Sierra-Del Rio, Daniel Sanín-Villa

9:45 "Aerodynamic Performance Evaluation of a NACA 4415 Profile by means of Computational Fluid Dynamics", Juan Diego Bentancur, Juan Gonzalo Ardila

\section{0:00 Coffee Break}

10:30 KNS-15 Fernando Macho Hernantes, "Chatbots, Artificial Intelligence, Natural Language Processing and Deep Learning in the Energy Field"

11:00 "Study in Thermal Photovoltaic Panels Cooled by Heat Sinks modelled by Computational Fluid Dynamics", Yustin Roman, Jorge Sierra

11:15 KNs-16 Natalia Rojas, "Aquatic Renewable Energy Potential in Colombia"

11:45 "Central Location Optimal Distributed Generation to Minimize Effects of Harmonics in Power Distribution Networks: Dominican Republic Case Study" Manuel A. Landron-Jeréz, Richard Gil-Herrera

12:00 Conclusions

\section{2:15 Lunch}

13:30 KNs-17 Fernando Colmenares, "Renewable Energy Solutions for Off-grid Zones"

14:00 "Optimal Equalization of Distributed Energy Storage Systems in a Microgrid", Nelson L. Díaz, Adriana C. Luna
14:15 "Reference Model for Smart Technologies Management based on National Science and Innovation Policy for Sustainable Development - Colombia, Agenda 2030", Gina Maestre-Góngora

14:30 KNs-18 Argiro Ramírez, "Strategic Plan for Marine Sciences and Hydrological Resources in Colombia 2018-2028 National Program"

15:00 "Termohaline Characterization of the Gulf of Urabá Central Region, from the Atrato River Discharge", Juan Carlos Guevara-Aguirre, Luis Alfredo Velásquez-Ortega, Vladimir G. Toro, Reginaldo Durazo-Arvizu

15:15 "ICT and its Incidence in the Productive Innovation of Renewable Energies", Darío Quiroga

\section{5:30 Coffee Break}

16:00 KNS-19 Daniel Portnoy, "Use of Autonomous Drones for Monitoring, Surveillance and Security"

16:30 "Trends of Microgrid as an Architecture for the Modernization of Eenergy Use", Julián Andrés Mera-Paz

16:45 "Technological Strategy for the Installation of an Energy Solution for the Catatumbo Region", Alfredo Bohórquez, Torcoroma Velásquez, Hugo Castro

17:00 "Renewable Energy Actions in the Coffee Region of Caicedonia - Valle del Cauca Department", Jhon Edwin Cerón

17:10 Conclusions

\section{Thursday, September 20}

Meeting: Industry, Academy and Government

\section{8:00 -13:00 Workshop}

- About vтt Technical Research Centre of Finland

- About UCC \& RUTA-N 
- Co-creating research and innovation cooperation between Colombia and Finland

- Promotion of large companies' investments for manufacturing various specialty papers and cardboard grades, using locally produced pulps.

- Encouragement for large companies to consider investments in the exploitation of aquatic renewable energy and different types of pulp mills, including the production of market pulp.

- Support for local sME's (including university spin-offs) to develop novel fractionation and processing systems for advanced biorefining of local wood, aquatic biomass and other raw materials to generate optimal product mixes.

- Investments in the separation of lignin and hemicellulose-based byproducts from aquatic biomass and forest industry operations, and their further conversions to marketable (domestic, international) intermediate or end-products.

- Encouragement for network creation that combines the use of different residues and wastes from forest industry and other sectors to form aquatic biomass to produce biochemicals, materials and renewable energy.

- With the help of $\mathrm{R} \& \mathrm{D}$ resources, find value-added materials and chemical applications for aquatic biomass and wood barks available from saw mills. 
Keynote Speaker Abstracts 


\title{
Biomass Boon: Carbonaceous Magnetic Materials in Sustainable Chemical Syntheses
}

\author{
Rajender S. Varma ${ }^{* * *}$
}

\footnotetext{
Regional Centre of Advanced

Technologies and Materials, Palacky

University, Olomouc, Czech Republic

* National Risk Management Research Laboratory, US EPA, Cincinnati, Ohio, USA

E-mail:

varma.rajender@epa.gov
}

\section{Introduction}

Sustainable endeavours for the greener synthesis of assorted nanoparticles [1-2] and their diverse applications as reusable nano-catalysts in eco-friendly mediums are of vital importance for synthesis. $\mathrm{Cu}, \mathrm{Ni}, \mathrm{Pd}, \mathrm{Ru}, \mathrm{Ce}$, etc., immobilized on biodegradable and recyclable earth-abundant supports - namely cellulose, chitosan or magnetic ferrites via ligands such as dopamine or glutathione - have been quite popular [3-5]. The value of heterogenized bimetallic Ag-Pd nanoparticles on graphitic carbon nitride (AgPd@g- $\mathrm{C}_{3} \mathrm{~N}_{4}$ ) may be accentuated by upgrading biofuel via hydrodeoxygenation of vanillin under visible light conditions, using formic acid as a hydrogen source [4]. Photocatalytic C-H activation [5a] using VO@g-C3N4 catalyst for direct oxidative esterification of alcohols [5b], oxygen insertion reaction in hydrocarbons [5c], selective oxidation of alcohols [5d] and hydrogenation of alkenes and alkynes [5e] using visible light as the source of energy will be described. These strategies exploit the utilization of waste that can sustainably generate $\mathrm{N}$-enriched carbonaceous catalytic materials valuable for obtaining greener transformations with trifling environmental impact. Sustainable route to nanoparticles using waste from winery [6a], or biodiesel by-products, glycerol [6b-c] and its applications in catalysis (magnetic nano-catalysts or organocatalysts), [7] and environmental remediation [8] will be highlighted. The utility of magnetic ZsM- 5 zeolite for the appraisal of furfuryl alcohol [9] and the ability of metal-exchanged magnetic b-zeolites for the conversion of lignocellulosic biomass-derived compounds to platform chemicals [10] will be explained. 


\section{References}

1. R.S. Varma, Green Chem., 16 2027, 2014; R.S. Varma, ACs Sustain. Chem. Eng., 4 5866. 2016.

2. R.S. Varma, Curr. Opin. Chem. Eng., 1 123. 2012.

3. R.B.N. Baig, M.N. Nadagouda, R.S. Varma, Coord. Chem. Rev., 287 137. 2015.

4. S. Verma, R.B. Nasir Baig, M.N. Nadagouda, R.S. Varma, Green Chem., 18 1327. 2016; S. Verma, R.B. Nasir Baig, M.N. Nadagouda, R.S. Varma, Green Chem., 181019. 2016.

5a. S. Verma, R.B.N. Baig, C. Han, M.N. Nadagouda, R.S. Varma, Chem. Commun., 51 15554. 2015.

5b. S. Verma, R.B.N. Baig, C. Han, M.N. Nadagouda, R.S. Varma, Green Chem., 18 251. 2106.

5c. S. Verma, R.B.N. Baig, M.N. Nadagouda, R.S. Varma, ACS Sustain. Chem. \& Eng., 4 2333. 2016.

5d. S. Verma, R.B.N. Baig, M.N. Nadagouda, R.S. Varma, ACS Sustain. Chem. \& Eng., 4 1094. 2016.

6a. R.B.N. Baig, S. Verma, M.N. Nadagouda, R.S. Varma, ACs Sustain. Chem. \& Eng., 4 1661. 2016.

6b. B. Baruwati, R.S. Varma, ChemSusChem, 2 1041. 2006 6c. J. Kou, R.S. Varma, Chem. Commun., 49 692. 2013.

7. J. Kou, R.S. Varma, ACS Sustain. Chem. Eng.,1 810.2013.

8. R.B.N. Baig, R.S. Varma, Chem. Commun., 49752. 2013; Gawande, M.; Branco, P.; Varma, R.S. Chem. Soc. Rev., 42 3317. 2013; R.B.N. Baig, R.S. Varma, Green Chem., 15 398. 2013; R. Hudson, Y. Feng, R.S. Varma, A. Moores, Green Chem., 16, 4493. 2014; R.B.N. Baig, M.N. Nadagouda, R. S. Varma, Green Chem., 162122. 2014.

9. J. Virkutyte, B. Baruwati, R.S. Varma, Nanoscale, 21109. 2010; J. Virkutyte, V. Jegatheesan, R.S. Varma, Bioresource Tech., 113 288. 2012; M. Pelaez, B. Baruwati, R. S. Varma, R. Luque, D. D. Dionysiou, Chem. Commun., 49 10118. 2013; A.D. Dwivedi, S.P. Dubey, M. Sillanpää, Y.-N. Kwon, C. Lee, R.S. Varma, Coord. Chem. Rev., 287 64. 2015

10. T.M. Lima, C.G.S. Lima, A.K. Rathi, M.B. Gawande, J. Tuček, E.A. Urquieta-González, R. Zbořil, M.W. Paixão, R.S. Varma, Green Chem., 18 5586. 2016

11. E.Y.C. Jorge, T. de M. Lima, C.G.S. Lima, L. Marchini, W.N. Castelblanco, D.G. Rivera, E.A. Urquieta-González, R.S. Varma, M. W. Paixão, Green Chem., 19 385. 2017. 


\title{
Textile Waste Recycling by Biological Methods
}

\author{
Carol S. K. Lin ${ }^{*}$ Xiaotong $\mathrm{Li}^{*}$, Chenyu Du ${ }^{* *}$, Shao-Yuan Leu ${ }^{* * *}$, Nattha Pensupa ${ }^{* * * *}$
}

School of Energy and Environment, City University of Hong Kong, Tat Chee Avenue, Kowloon, Hong Kong

E-mail:

carollin@cityu.edu.hk

** School of Applied Sciences, University of Huddersfield, Huddersfield, HD1 3DH, United Kingdom

*** Department of Civil \& Environmental Engineering, Hong Kong Polytechnic University, Hong Kong

****Department of Agro-Industry, Faculty of Agriculture, Natural Resources and Environment, Naresuan University, Phitsanulok, Thailand

\section{Introduction}

In order to recover glucose and polyester from textile waste, enzymatic hydrolysis of textile waste pre-treated by different modification methods was investigated. The effects of key factors related to the hydrolysis process were evaluated, including substrate loading, temperature, $\mathrm{pH}$, cellulase dosage, and supplementation of $\beta$-glucosidase. Results showed that freezing $\mathrm{NaOH} /$ urea could contribute to a significant increase of the hydrolysis yield compared with untreated textile waste, from $57.7 \%$ to $98.3 \%$. Increasing substrate loading from $1 \%$ to $7 \%(\mathrm{w} / \mathrm{v})$ had a negative effect on glucose recovery yield and a significant inhibitory effect was observed over $3 \%$ substrate loading. Substrate loading at $3 \%$ was selected based on glucose yield. The optimal temperature for enzymatic hydrolysis was $50{ }^{\circ} \mathrm{C}$ and significant reduction was observed over $60^{\circ} \mathrm{C}$. There was no significant increase of glucose recovery yield when cellulase loading was over $20 \mathrm{FPU} / \mathrm{g}$ and $\beta$-glucosidase loading was over $10 \mathrm{U} / \mathrm{g}$. Therefore, the optimum enzymatic hydrolysis condition was using $20 \mathrm{FPU} / \mathrm{g}$ cellulase and $10 \mathrm{U} / \mathrm{g}$ $\beta$-glucosidase at $50^{\circ} \mathrm{C}$ and $\mathrm{pH} 5$, based on the criterion for minimizing enzyme dosage and maximizing glucose recovery. The maximum glucose recovery yield of $98.3 \%$ was achieved after $96 \mathrm{~h}$ hydrolysis.
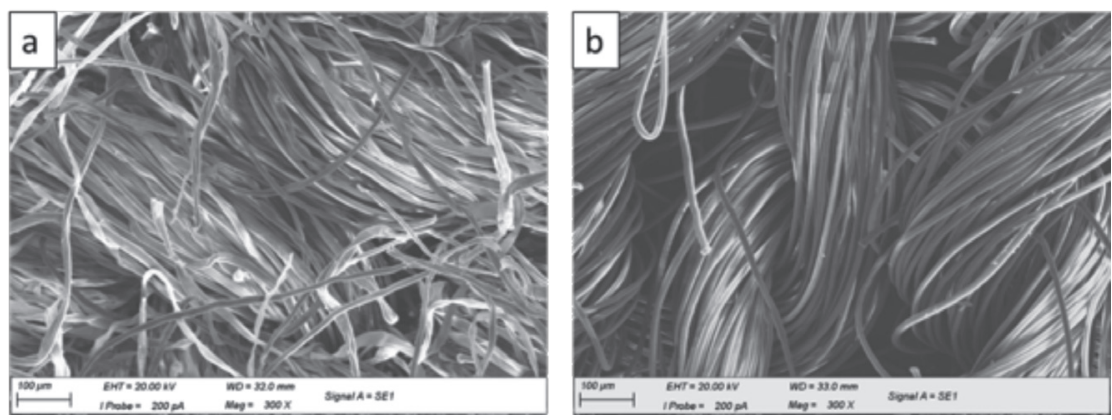

Figure 1. SEM pictures of textile substrate (pretreated 60/40) before and after enzymatic hydrolysis, (a) pretreated textile fibres before hydrolysis at $\times 300$ magnification; (b) pretreated textile fibres after hydrolysis at $\times 300$ magnification. 


\title{
Clean processes - Biodegradation of waste gases in a Compact Trickle Bed Bioreactor as an Economically Attractive way of Waste Gas Treatment in Paint Industry
}

\author{
Damian Kasperczyk ${ }^{*}$, Ramón F. Colmenares-Quintero ${ }^{* *}$, K. Urbaniec ${ }^{* * *}$, K. Barbusiński ${ }^{* * *}$
}

Ekoinwentyka Ltd, Ruda Śląska, Poland

** Universidad Cooperativa de Colombia, Colombia

*** Warsaw University of Technology, Plock, Poland

***Silesian University of Technology, Gliwice, Poland

E-mail:

biuro@ekoinwentyka.pl

\section{Introduction}

Volatile organic compounds (vocs) and odours are the key atmospheric pollutants characterized by significant ozone depletion and global warming potential, toxicity and carcinogenicity [1-2]. Industrial vocs and odour emissions coming mainly from chemical and petrochemical plants, deep and open-pit mines, wastewater treatment plants, paint industry etc. - are subject to increasingly stringent environmental regulations [1-3]. Among a number of voc removal technologies available for treating the polluted air streams, the biological treatment method is particularly interesting as it is based on the natural ability of microorganisms to degrade pollutants, and it does not shift the pollution problem from air to other environmental compartments, that is, to water or soil. Although applications of bioprocess engineering to waste management are relatively new, the industries have recognized important advantages of biodegradation of vocs such as mild process conditions including low pressure and temperature, absence of explosion risk, and safety for people and the environment. It has also been reported that investment and operating costs of biodegradation are lower than those of the chemical voc abatement methods [1]. The present study concerns experimental preliminary results of an on-going EU project (POIR.01.01.01-00-0664/17) that seeks to develop and adapt biopurification technologies from vocs in Compact Trickle Bed Bioreactor (ствв) to new branches of industries, such as the paint industry.

\section{Experimental}

The experiments were performed using a semi-industrial scale stainless steel ствв, diameter $\mathrm{d}=0.315 \mathrm{~m}$ and bed high $\mathrm{h}=0.65 \mathrm{~m}$, in which the gas and liquid phases flowed co-currently in downward direction through a bed made of polyethylene rings. The bioreactor was inoculated with a co-culture of microorganisms including bacterial strains commonly present in the paint industry; these microorganisms were adapted to the respective pollutants. At gas-flow rates varying between 1.0 and $5.0 \mathrm{~m}^{3} / \mathrm{h}$ and for voc concentration on inlet to Ствв Cgin $=5-125 \mathrm{mg} /$ 
$\mathrm{m}^{3}$, the liquid-flow rates were changed between 1.2 and $1.4 \mathrm{~m}^{3} / \mathrm{h}$. In а ствв the gas was carried through a packed bed continuously irrigated with an aqueous solution containing essential nutrients needed for the microorganisms that grow as biofilm on the packing material of the reactor bed. The pollutant to be treated is initially absorbed by the aqueous film that surrounds the biofilm and then biodegradation takes place within the biofilm [2]. A schematic presentation of the biotrickling filter is given in Figure 1.

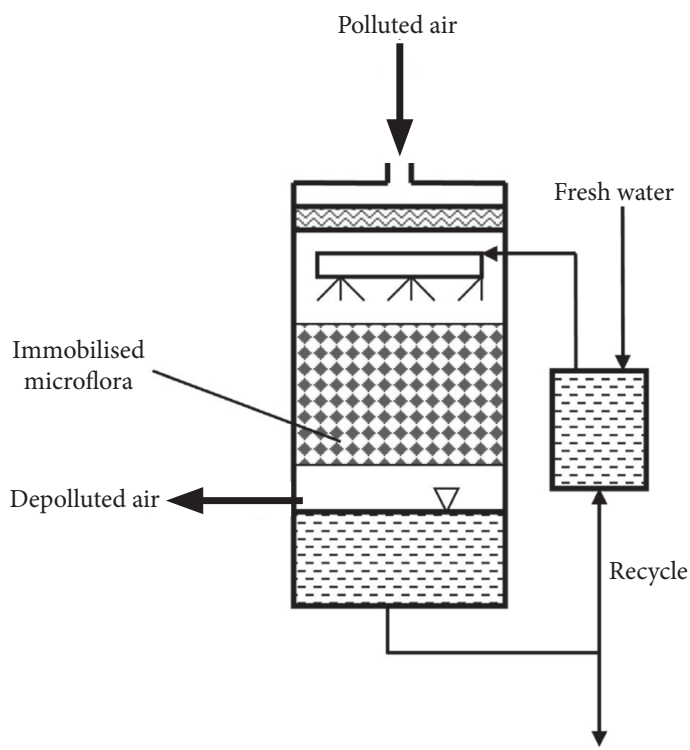

Figure 1. Schematic of a biotrickling filter $[4,5]$

\section{Results and Discussion}

Selected results of an on-going EU project (POIR.01. 01.01-00-0664/17) conducted by Ekoinwentyka Ltd are presented. The project's aim is to design, test and apply a compact trickle-bed bioreactor operated in a biofiltration system with circulating salt solution for the biodegradation of vocs in the paint industry. The start-up conditions were chosen as $\mathrm{T}=302 \pm 3 \mathrm{~K}$ and $\mathrm{pH}=7.0 \pm$ 0.3. The immobilization of microflora onto the packing material took about 11-12 days on average. After that period, the conversion factor of biodegradation -determined at the gas-phase flowrate $\mathrm{Vg}=2,5 \mathrm{~m}^{3} / \mathrm{h}$ and inlet voc concentration $\mathrm{Cgi}_{\mathrm{n}} 0=8.0 \mathrm{mg} / \mathrm{m}^{3}$ - typically reached $\mathrm{K}=89-95 \%$ proving that the adaptation of microflora to the pollutant mixture was very good. The overall results of laboratory capacity tests of ствв bioreactor carried out at the industrial research stage are presented in Figure 2.

\section{Conclusions}

The experiments proved satisfactory activity of the chosen bacterial co-culture applied to the biodegradation of vocs from the paint industry. The results of the presented research constitute a base for the second part of the project PoIR.01.01.01-00-0664/17 that is currently being implemented. The current part of the project includes the installation, commissioning and testing of ствв in industrial conditions for the

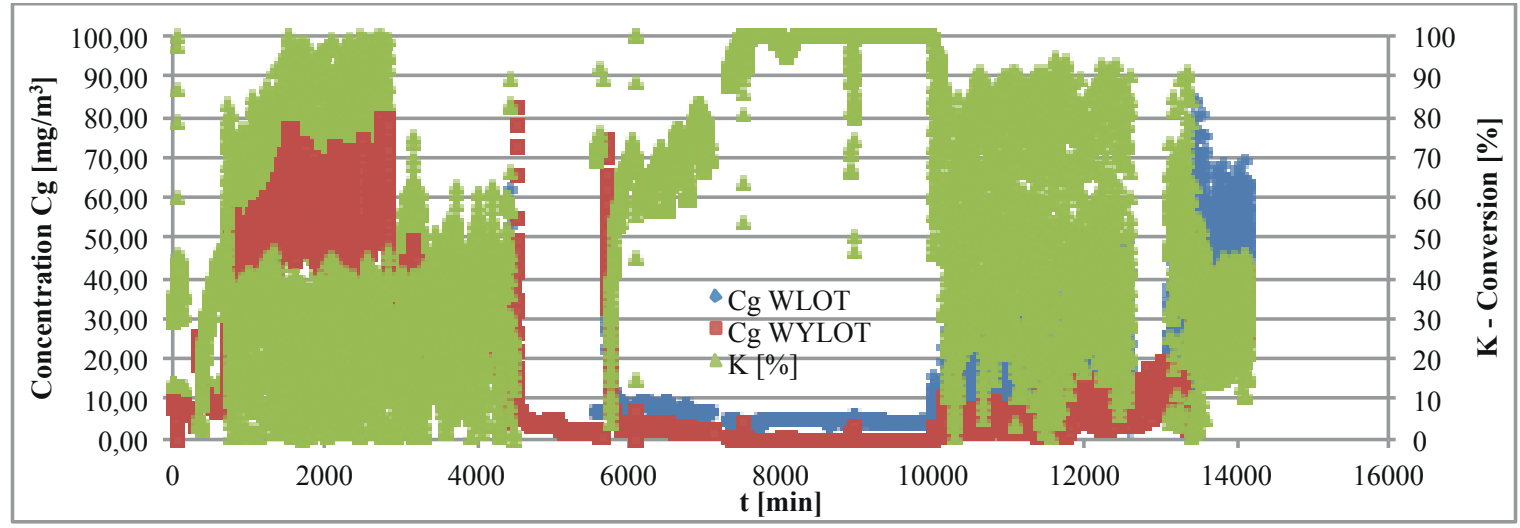

Figure 2. Overall results of laboratory capacity tests of ствв bioreactor carried out at the industrial research stage 
gas phase flow of 5,000 - 10,000 $\mathrm{m}^{3} / \mathrm{h}$. The experimental program is continued to optimize key process parameters such as gas and liquid flow rates, temperature, $\mathrm{pH}$ of the liquid, and physiological parameters of biomass growth.

\section{Acknowledgements}

The author gratefully acknowledges the financial support from the European cosT Action FP1306 promoting networking and collaboration.

Research was carried out thanks to the financing of EU Project: POIR.01.01.01-00-0664/17

\section{References}

D. Kasperczyk, K. Urbaniec, J Clean Prod., 87 971. 2015.

K. Barbusinski, K. Kalemba, D. Kasperczyk, K. Urbaniec, V. Kozik, J Clean Prod., 152 223.2017.

J. A. Nicell, Atmos Environ., 43 196. 2009.

M. C. Delhomenie, M. Heitz, Crit Rev Biotechnol., 2553. 2005.

D. Kasperczyk, K. Urbaniec, K. Barbusinski, R. R. Eldon, R. F. Colmenares-Quintero, Proceedings of the 1st Latin American Conference on Sustainable Development of Energy, Water, and Environment Systems, LA. SDEWES2018.0151, 1-9. 


\section{Examples of Recent Global Trends in Wood-Based Biorefining}

Klaus Niemelä*

vTт Technical Research Centre of
Finland Ltd, Finland
E-mail:
klaus.niemela@vtt.fi

\section{Introduction}

The current pulp and paper industry uses annually more than 300 million tons of wood raw material for chemical and mechanical pulping processes. For more than 100 years, chemical pulping processes have provided fascinating examples of biorefinery operations due to the production of various by-products: chemicals, materials, biofuels, and electricity. Currently, there is a clear tendency to convert the pulp mills into even more advanced biorefineries (bioproduct mills), by increasing the volume and number of products, other than pulp and paper. This presentation will give a global overview of selected pulp mill biorefining trends, together with some remarks on other types of wood-based biorefineries. Selected innovative historical processes will also be briefly discussed.

\section{Pulp Mill Biorefineries}

In the chemical pulping processes, approximately $50 \%$ of wood raw material is recovered as cellulosic fibre for paper and paperboard production, the rest is dissolved in the cooking liquor. Depending on the pulping process $(\mathrm{pH})$, these liquors provide different opportunities for advanced biorefining. The dominating pulping process, alkaline kraft process, has traditionally been an important source of turpentine and tall oil (for fatty and resin acids and phytosterols), although some lignin has also been recovered for chemical uses for several decades. Recently, there has been a lot of interest in increasing the recovery of lignin, hemicellulosic sugars or polymers, methanol, and other potential products such as aliphatic hydroxy acids (from glycolic acid to saccharinic acids). As a result, several new demo or mill scale installations have been set up in different countries.

The less common acidic sulphite pulping process provides exciting opportunities for advanced biorefining operations. The current by-products include lignosulphonates (more than 1 million tons), acetic acid, furfural, xylose for xylitol, and other sugars for ethanol, yeast products, and ribonucleic acids. There are several advanced multi-product sulphite pulp mills currently in operation, and new lignosulphonate recovery systems have also been set up. There is also one plant where some vanillin is produced by oxidation of lignosulphonates. Novel 
pulping processes are represented by those based on the use of organic solvents, ionic liquids, or deep eutectic solvents. Of them, only some organosolv processes have been demonstrated in higher scales. All pulping processes also yield high volumes of bark and other residues; specific biorefineries based on them are under development.

\section{Other Wood Biorefineries}

The stand-alone wood-based biorefineries, not integrated to pulp and paper production, include different pretreatment hydrolysis fermentation systems for biofuels and biochemicals, direct chemical (degradative) processes, and thermal processes, such as pyrolysis under different conditions. In all these areas there have been various pilot-demonstration (or almost mill-scale) activities showing promising potential for further development. The isolation of chemicals from bio-oil or from charcoal production streams is also attracting a lot of interest. It is noteworthy that in the past many important industrial chemicals (e.g. methanol, acetone, acetic acid, oxalic acid) were available almost exclusively from different thermal wood-based processes.

\section{Nordic Wood Biorefinery Conferences}

The recent rapid progress in many areas of woodbased biorefineries prompted Innventia (now part of RISE) and VTT to initiate in 2008 a series of International Nordic Wood Biorefinery Conferences, to be held every 18 months in Sweden and Finland in turn. The last $\left(8^{\text {th }}\right)$ event took place in Helsinki, Finland, in October 2018. The proceedings' books of the NWBC 2012 and NWBC 2015 events are freely available for download.

\section{Acknowledgements}

The author wishes to acknowledge the contribution of COST Action FP1306 via promoting networking and collaboration. 


\title{
Selective Fractionation and Conversion of Biomass via Thermochemical and (Bio)Catalytic Processes
}

\author{
Konstantinos S. Triantafyllidis ${ }^{\star * *}$
}

\footnotetext{
Department of Chemistry, Aristotle University of Thessaloniki, Greece

** Chemical Process \& Energy

Resources Institute, CPERI/CERTH,

Thessaloniki, Greece

E-mail:

ktrianta@chem.auth.gr
}

\section{Introduction}

The valorisation of waste biomass, lipid or lignocellulosic, has been proposed as an alternative to first-generation biofuels as well as for producing high-value chemicals and related products. In the case of agricultural or forestry lignocellulosic biomass wastes and residues, the "whole biomass" refining concept should be applied in order to develop sustainable valorisation schemes. The pretreatment/fractionation of biomass to its basic structural components, i.e., cellulose, hemicellulose and lignin, is a prerequisite for maximizing their selective conversion towards high added value platform chemicals, fuels and polymers. In this presentation, specific case studies of individual processes that comprise an integrated biorefinery scheme for converting agricultural and forest biomass wastes to valuable chemicals and fuels is described. Fractionation of biomass is based on "green" hydrothermal processes, leading to selective isolation of hemicellulose stream for downstream conversion to ethanol or furanic chemicals. The cellulose fraction is being hydrolysed to glucose by applying well-known enzymatic hydrolysis reactions. Alternatively, lignin is extracted from the pretreated biomass under mild conditions using friendly/recoverable solvents, providing with a high purity cellulose pulp for easier enzymatic hydrolysis or catalytic hydrogenolysis to sorbitol/glycols. To close the cycle, the recovered lignin, is being converted to high value phenolics via fast pyrolysis or hydrogenolysis. Using catalytic fast pyrolysis, BTX mono-aromatics can be selectivity produced. Alternatively, lignin is being utilized as a compatible bio-additive in polymers (resins) with a minimum downstream conversion cost. 


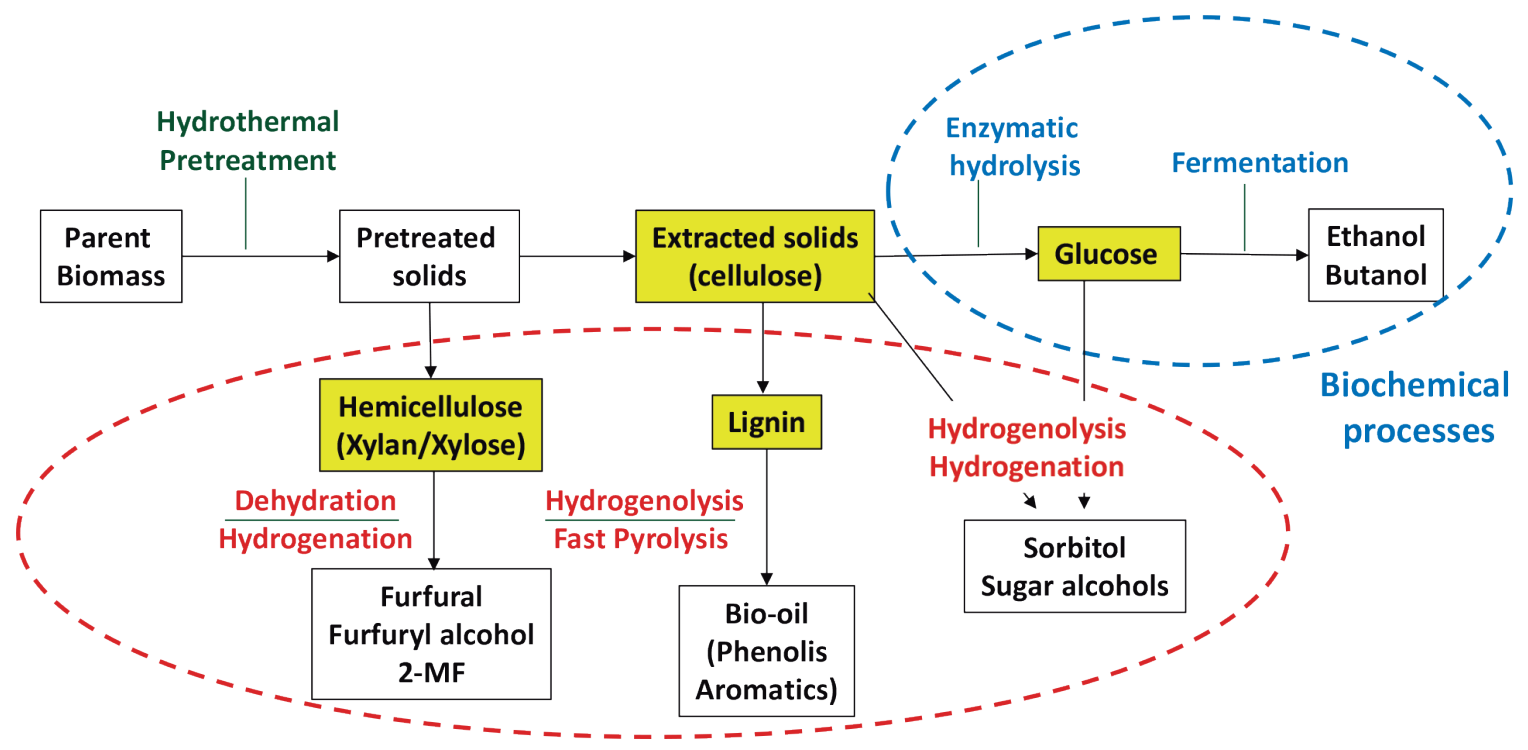

Chemo-catalytic processes

Figure 1. "Whole biomass" integrated biorefinery scheme

\section{Acknowledgements}

This work has been partially supported by the project "INVALOR: Research Infrastructure for Waste Valorisation and Sustainable Management" (MIS 5002495) which is implemented under the Action "Reinforcement of the Research and Innovation Infrastructure", funded by the Operational Program
"Competitiveness, Entrepreneurship and Innovation" (NSRF 2014-2020) and co-financed by Greece and the European Union (European Regional Development Fund). The support of cosT Action FP1306 promoting networking and collaboration, and the Short Term Scientific Missions (sTSM's) funding of young researchers are also gratefully acknowledged. 


\title{
Benign By-Design Processes for Sustainable Biomass/Waste Valorisation
}

\author{
Rafael Luque*,**
}

Departamento de Química Orgánica, Universidad de Córdoba, Córdoba, Spain

** Peoples Friendship University of Russia (RUDN University), Moscow, Russia

E-mail:

rafael.luque@uco.es

\section{Introduction}

The design of benign and environmentally sound methodologies has been the driving force of scientists in recent years towards more sustainable methodologies. In recent years, attractive and innovative protocols that nowadays are even part of industrial ventures including biomass-derived porous carbonaceous materials, designer nanomaterials for catalytic applications, and catalytic strategies for biomass/waste conversion into useful materials, chemicals and fuels have been developed in our group. These topics have extensively covered the preparation and design of nanomaterials, biocatalysts and photocatalysts and their utilization in heterogeneously bio-, photo- and electro-catalysed processes, flow chemistry, as well as in biomass/waste valorisation practices [1-5].

In this lecture, we aim to provide an overview of recent efforts of the scientific community for leading the future of global scientists, chemical engineers, biochemists, environmentalists and material scientists in benign by-design methodologies for various types of catalyst systems and key applications in bio-, photo- and electrocatalysis.

\section{Acknowledgements}

The contribution of cosT Action FP1306 is gratefully acknowledged for promoting networking and collaborations. 


\section{References}

K. Shen, L. Zhang, X. Chen, L. Liu, D. Zhang, Y. Han, J. Chen, J. Long, R. Luque, Y. Li, B. Chen, Science, 359 206. 2018.

D. Rodríguez-Padron, A. Jodlowski, G. de Miguel, A. Puente-Santiago, A.M. Balu, R. Luque, Green Chem. 20 225. 2018.
L. Filiciotto, A.M. Balu, A.A. Romero, E. RodríguezCastellón, J.C. Van der Waal, R. Luque, Green Chem. 19 4423. 2017.

J. Lai, S. Li, F. Wu, M. Saqib, R. Luque, G. Xu, Energy Environ. Sci. 9 1210. 2016.

A.D. Jodlowski, A. Yepez, R. Luque, L. Camacho, G. de Miguel, Angew. Chem. Int. Ed. 55 14972. 2016. 


\title{
Biochar from Sustainable Resources and its Environmental Applications
}

\author{
Ondrej Mašek, W. Buss ${ }^{\star}$ Julian Pietrzyk*, Mingyu Hu${ }^{\star}$, Jan Mumme*, Andrew Free
}

uk Biochar Research Centre, School of GeoSciences, University of Edinburgh, Edinburgh, UK E-mail:

ondrej.masek@ed.ac.uk

\section{Introduction}

Biochar's potential to store atmospheric carbon has been estimated to be 0.7$1.8 \mathrm{Gt} \mathrm{CO} 2-\mathrm{C}(\mathrm{eq}) \mathrm{yr}^{-1}$. This presentation focuses on ways to achieve or increase such potential, while maximizing positive and minimizing potential negative environmental and economic impacts. The first part discusses the potential to integrate biomass pyrolysis into bioenergy systems and negative emission technologies to boost their performance for reducing greenhouse gas emissions and thus generating profit. While pyrolysis as a standalone technology has been under development and use for a number of decades, the focus on bio-oil production and waste management, as well as its integration in biorefineries is much more recent. This presentation examines different options and provides specific examples of ways to integrate pyrolysis with other thermochemical or biological systems into a zero-waste biorefinery, examples of which are schematically shown in Figure 1. Specific examples of benefits from such integration include:

1. Increased yield of methane and improved stability of AD reactors. Our results show that certain types of biochar can be used to control ammonia inhibition in $\mathrm{AD}$ reactors and to increase methane yield.

2. Upgrading of low-value aqueous fractions of pyrolysis liquids into methane or volatile fatty acids in AD reactors. While the organic fraction of bio-oil contained too many inhibitors to allow AD decomposition, the aqueous fraction could be successfully converted.

3. Beneficial use of mineral-rich residues from marine biomass utilization, offering controlled release of nutrients into soil or growing media, such as $\mathrm{K}$ and P. Our results show that most of the minerals are available, and their release dynamics can be controlled by adjusting pyrolysis conditions. 


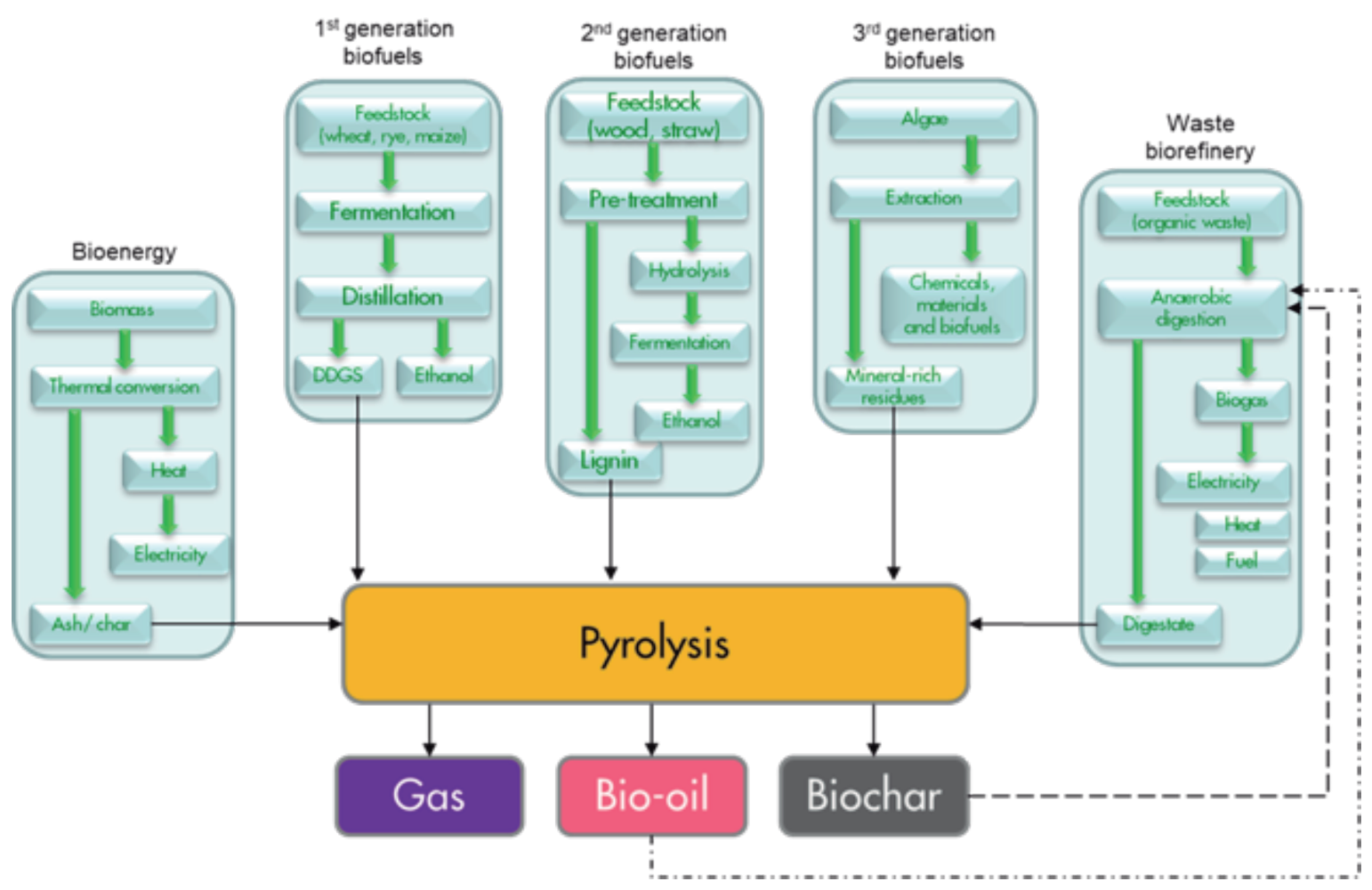

Figure 1. Possible ways for the integration of pyrolysis to other bioenergy technologies, both thermochemical and biological

The second part exposes the potential to use lowcost mineral additives to boost the yield of biochar by more than $50 \%$, and consequently increase its global carbon sequestration potential to over $2.6 \mathrm{Gt} \mathrm{CO}_{2-} \mathrm{C}_{(\mathrm{eq})}$ $\mathrm{yr}^{-1}$. This approach allows decoupling of economically viable biochar deployment for carbon sequestration purposes relying on biochar's abilities to improve soil properties. The potential to improve quality of soil and consequently improve crop productivity is an important added benefit of this technology, and one that in certain circumstances can make its deployment viable, even in the absence, or at a very low carbon price.

The first approach involves loading small percentages (1-2 wt \%) of potassium onto biomass feedstock prior to pyrolysis. The ability of alkaline metals (AMs) to catalyse biochar formation, together with the fact that potassium is a valuable macronutrient makes the use of AMs as additives in biochar production a potentially attractive proposition. This is especially true, if the Am catalysed biochar has at least similar or better properties in terms of carbon stability compared to biochar produced without AM doping.
Potassium doping showed a good performance, increasing both biochar and stable carbon (represented by fixed carbon) yields. The increase in biochar yield is a result of catalysis of the charring process by AM catalysts in the pyrolysis of lignocellulosic materials. In the presence of these metals the reaction process favours charring and dehydrating reactions, versus fragmentation and depolymerization pathways, in the primary decomposition of the holocellulosic fraction. In addition, AMs also enhance dehydration, demethoxylation, decarboxylation, and biochar formation in lignin pyrolysis. All K+ treatments considerably increased the stable carbon yield compared to the untreated controls. The relative change in biochar yield was between $+9.5 \%\left(1 \% \mathrm{~K}+650^{\circ} \mathrm{C}\right)$ and $+45.0 \%\left(2 \% \mathrm{~K}+450^{\circ} \mathrm{C}\right)$.

The second approach employed ash from biomass (wood) combustion as an additive mixed with woody biomass (spruce) prior to pyrolysis. To achieve an intimate and effective contact between the organic and mineral phases, the blended product was compressed into the shape of a pellet prior to pyrolysis. The combination of wood ash from a biomass boiler 
with milled spruce wood in different ratios (0-50 \%) and subsequent pyrolysis at $450{ }^{\circ} \mathrm{C}$ created novel biochar-ash composites. The biochar yield (after compensation for the increased ash content) increased by $40 \%$ with the addition of $20 \%$ and $50 \%$ wood ash, relative to pure pine due to catalysis of char formation. Besides the significant increase in biochar yield, the composite material also showed a strong buffering of mineral release into solution, evidenced by a low electric conductivity (EC) and available K (factor of 2.5-4.4 lower than the one in wood ash). This decreases the risk of salinity stress and leaching of $\mathrm{K}$ in soil applications. The use of ash-biochar composites has many benefits over the application of the individual materials and creates a product with greatly unexplored potentials for use in forestry and agriculture. 


\title{
Aligning Sustainable Energy Policy and Bioenergy System Innovation Using Modern QFD System's Thinking Methods
}

\author{
Kim E. Stansfield*, Mike Colechin ${ }^{\star *}$, Glenn H. Mazur ${ }^{\star * *}$, Ramón F. Colmenares-Quintero ${ }^{\star * * *}$
}

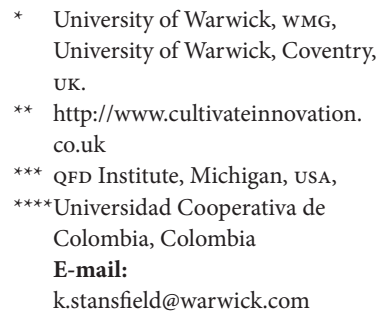

** http://www.cultivateinnovation. co.uk

*** QFD Institute, Michigan, USA,

****Universidad Cooperativa de

Colombia, Colombia

E-mail:

k.stansfield@warwick.com

\section{Introduction}

To increase the likelihood of technological innovation sustainability viz. long-term economic, market, social and environmental innovation in the renewable-energy sector, there is a need, not only to develop enhanced technologies, but to improve the coordination and collaboration between government policy developers, business model innovators, innovators within operational energy delivery systems and supply chains, and consumer behaviour innovations. This requires that more systematic ways of linking 'mission outcomes' and goals and the needs that drive business, social and technological innovations are deployed to achieve the desired transformations.

This paper introduces methods that have been used in businesses to integrate:

1. Policy deployment and management (Hoshin Kanri)

2. Stakeholder needs, structuring, prioritization and integration with systems design viz. Quality Function Deployment (QFD)

The authors describe how these approaches provide a framework that helps structure the analysis of the 'soft-systems problem space', with 'whole-system design' methods that address key stakeholder needs. This is proposed as an enhanced approach for sustainable innovation in the renewable-energy sector. In the process, these and supporting system methods naturally help facilitate 'whole system thinking' for the renewable energy sector.

This paper illustrates such approach using some developments carried out in Energy Technologies Institute for UK's sustainable bioenergy systems transition planning programme.

\section{Experimental}

The methods described were used to support identification, prioritization and structured discussions between key stakeholders in the development of bioenergy systems programme focused on the UK, and in support of a national renewable energy systems transition programme planning initiative. The chart illustrated in Figure 1 shows the deployment of national outcomes for 'Sustainable Energy Policy' to Government Departmental outcomes. 


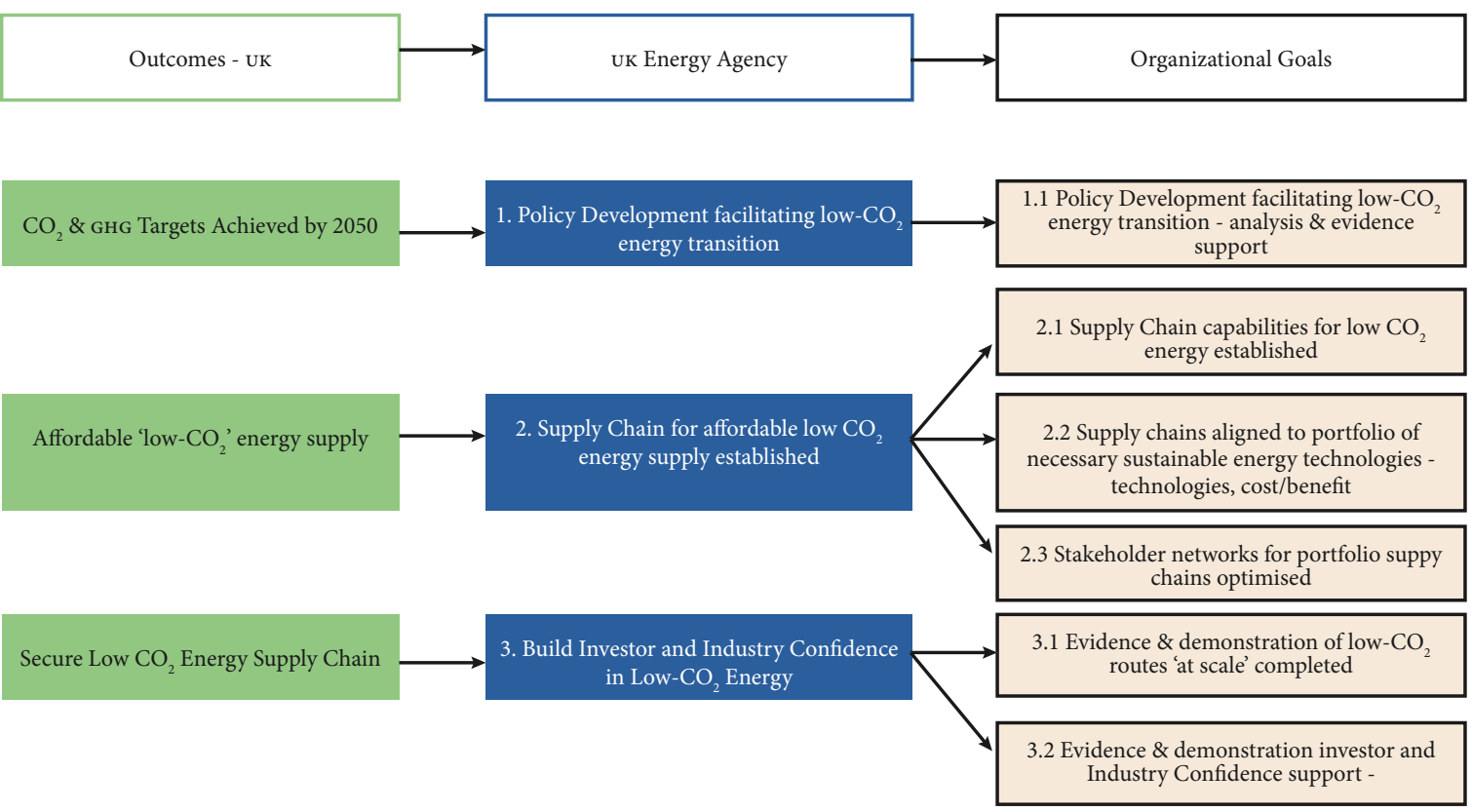

Figure 1. Illustration of national outcomes being deployed to support agency and organizational goals

\section{Results and Discussion}

Table 1. Illustration of a Maximum-value-table (MVT) for sustainable energy development

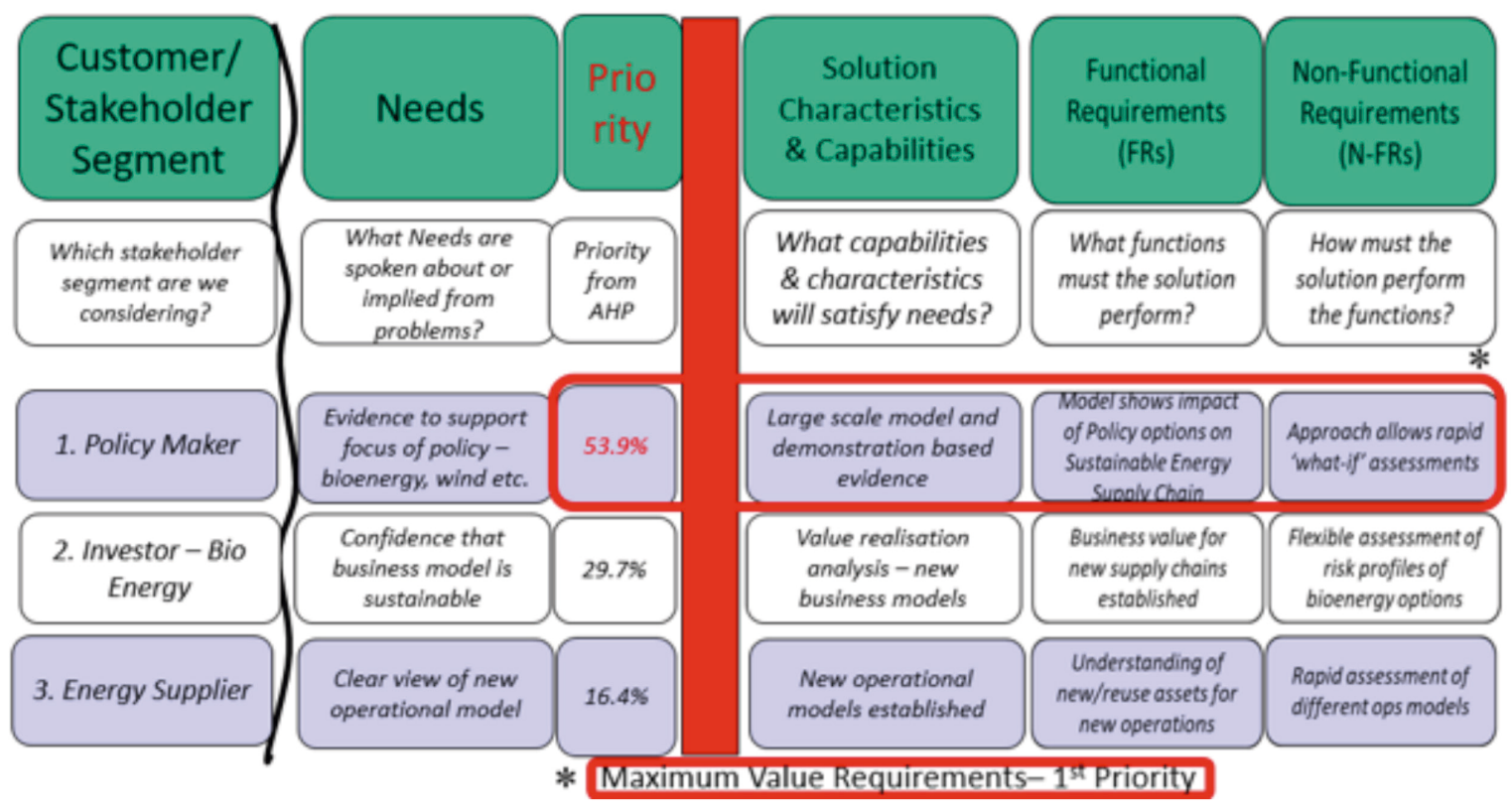


The paper illustrates the framework of system thinking approaches and methods that enable design and delivery of high-value, sustainable energy system solutions. The illustration of these methods shown in Table 1 includes a simplified extract from a maximum value table linking prioritized stakeholder needs and prioritized solution characteristics and capabilities with the requirements for bioenergy systems in the UK. This type of matrix provides key characteristics for analysing solution concepts for renewable energy systems, including bioenergy systems and will be further explained.

\section{Conclusions}

The authors have found that these approaches provide a useful framework supporting integration of policy development with stakeholder needs analysis for innovative, renewable energy system design. Not only does it provide a framework for improving the design of the whole system solution, but also provides systematic approaches for developing appropriate low carbon solutions.

\section{Acknowledgements}

The authors would like to acknowledge the support of the CosT Action FP1306 in supporting the promotion and networking communications for this work.

\section{References}

International Standards Organization, "Applications of statistical and related methods to new technology and product development process - Part 1: General principles and perspectives of Quality Function Deployment (QFD)". ISO 16355-1:2015, Geneva, Switzerland: International Standards Organization. 2015.

K. Stansfield, C. M. Colechin and G. Mazur, 22nd International Symposium on QFD., Boise, USA, 2016. 


\title{
Microbial Biogas Production from Hydrolysis Lignin: Insight into Lignin Structural Changes
}

\author{
Daniel G. Mulat*, Janka Dibdiakova**, Svein J. Horn*
}

Faculty of Chemistry, Biotechnology and Food Science, Norwegian University of Life Sciences, Norway.

** Norwegian Institute of Bioeconomy Research, Norway

E-mail:

jad@nibio.no

\section{Introduction}

The emerging cellulosic bioethanol industry will generate huge amounts of lignin-rich residues that may be converted into biogas by anaerobic digestion (AD) to increase the output of energy carriers from biorefinery plants [1]. The carbohydrate fraction of lignocellulosic biomass is degradable, whereas the lignin fraction is generally considered difficult to degrade by anaerobic digestion (AD). The objective of this study was to investigate the feasibility of biogas production by AD from hydrolysis-lignin ( $\mathrm{HL}$ ), prepared by steam explosion (SE) and enzymatic saccharification of birch. HL was characterized before and after AD by NMR, Py-GC/MS and FTIR to identify recalcitrant and degradable structures in the lignin.

\section{Experimental}

Birch (Betula pubescens) wood chips milled to pass a sieve of $6 \mathrm{~mm}$ were used in this study. Steam explosion of birch for biogas production was used applying the optimal conditions at $210^{\circ} \mathrm{C}$ and $10 \mathrm{~min}$ residence time. The pretreated birch was subjected to enzymatic hydrolysis using Cellic ${ }^{\circledR}$ CTec2 (Novozymes, Bagsvaerd, Denmark; total protein concentration $63.9 \mathrm{mg} / \mathrm{ml}$ ). The biogas production of untreated, steam-exploded and $\mathrm{HL}$ birch was studied in $500 \mathrm{~mL}$ batch bottles. The degradation of $\mathrm{HL}$ in $\mathrm{AD}$ was investigated by enclosing the substrates in nylon bags. The chemical structure, morphology and thermal properties of $\mathrm{HL}$ and the remaining undigested material after $\mathrm{AD}$ was characterized using a combination of advanced analytical techniques, including NMR, FTIR, STA, SEM and Py-GC/Ms. 


\section{Results and Discussion}

\section{Biogas potential of hydrolysis lignin}

The initial rate of methane production of pretreated and HL birch was higher than that of untreated birch, indicating an increased accessibility of the birch material to anaerobic bacteria after SE pretreatment. While the steam-exploded birch reached maximum methane yield after 16 days, the untreated material needed 39 days to reach similar yields. Thus, the main effect of steam explosion treatment centres on the rate of methane production, not on the final yield. The final methane yield of $\mathrm{HL}$ birch was $125 \mathrm{~mL} \mathrm{CH} 4 / \mathrm{g}$ volatile solid, reached after 16 days of incubation.

\section{Insight into lignin structural changes after pretreatment and $\mathrm{AD}$}

The change in lignin structure after sE pretreatment was investigated by comparing the HSQC spectra between untreated birch and birch HL (Figure 1). The $\beta-\mathrm{O}-4$ ' linkage was substantially reduced from $67 \%$ in untreated birch to $18 \%$ in $\mathrm{HL}$, showing the susceptibility of this major lignin linkage to SE pretreatment. The s/G ratio of $\mathrm{HL}$ increased from 2.8 in untreated birch to 5.8, and the cross-peak of S [2-3] at $\delta \mathrm{C} / \delta \mathrm{H} 105 / 6.6 \mathrm{ppm}$ became broad, indicating formation of pseudo-/condensed-lignin. The FTIR analysis further demonstrated the removal of carbohydrates and enrichment of the lignin fraction in the HL after enzymatic hydrolysis of the pretreated birch. The HL birch after AD showed similar profiles as the original HL material, but lower intensities were observed for the bands at 1735-1710, 1325, 1214 and $1114 \mathrm{~cm}^{-1}$ in the former. The reduction in intensity of these bands is consistent with the degradation of condensed-/ pseudo-lignin and removal of hemicelluloses shown by the HSQC NMR analysis. In comparison to NMR analysis, the S/G ratio was slightly underestimated by Py-GC/Ms. The proportion of $\mathrm{H}$ type units reached less than $6 \%$ of all lignin derived pyrolysis products and was not detected by the NMR analysis. This difference is expected due to the higher sensitivity of mass spectrometry and the possibility of the $\mathrm{H}$ type unit fragments reduction originating from non-lignin components like aromatic amino acids during pyrolysis.
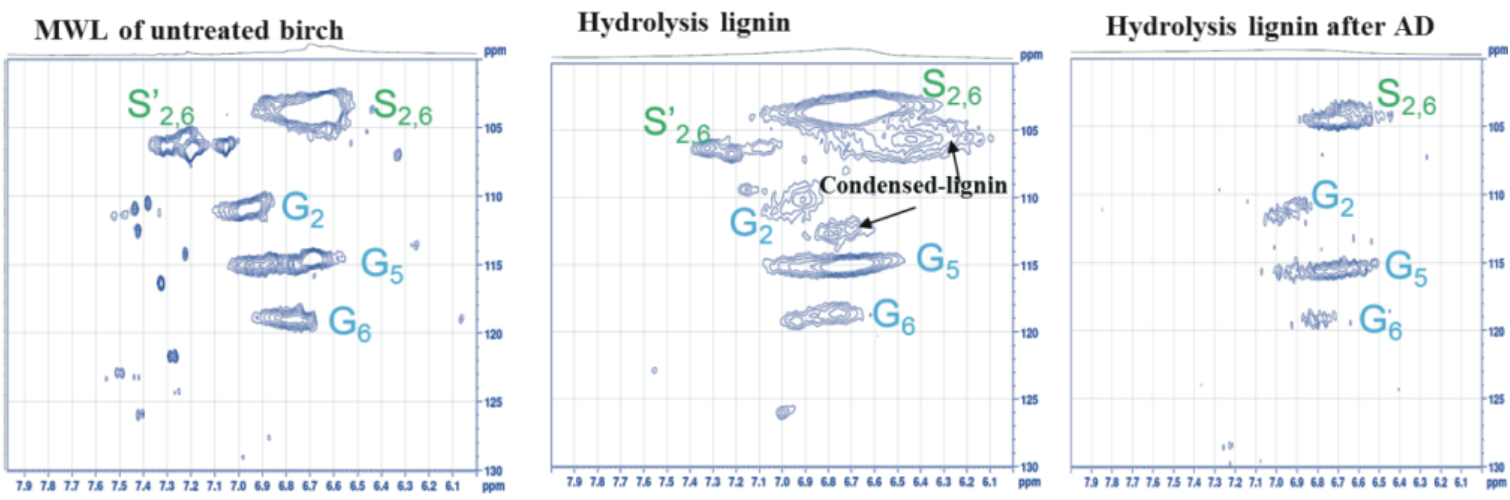

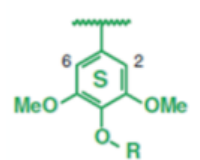

Syringyl

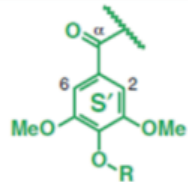

$S^{\prime}$

Syringyl

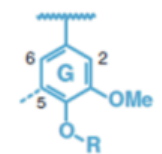

G

Guaiacyl

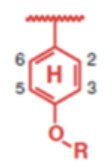

$\mathrm{H}$

p-Hydroxyphenyl

Figure 1. The 2D HSQC NMR spectral regions of interest (aromatic region) of untreated birch (MWL), HL before and after AD and the structures of main lignin units and lignin inter-unit linkages. 
SEM and STA measurements demonstrated changes in morphology and thermal properties following SE pretreatment and AD. Our results showed that carbohydrate and pseudo-/condensed-lignin degradation had contributed to methane production.

\section{Conclusions}

The lignin-rich material (HL) obtained after enzymatic extraction of carbohydrates has potential to be used for methane production. HL birch contained up to 80 $\%$ lignin with a highly condensed structure due to competing lignin depolymerization (mainly through cleavage of the abundant $\beta-\mathrm{O}-4$ ' inter-unit linkages) and re-condensation reactions. The results from biogas potential tests, NMr, Py-GC/Ms and fTIR analysis indicate that the carbohydrate fraction and part of the lignin fraction in $\mathrm{HL}$ birch were degraded during $\mathrm{AD}$. Pseudo-/condensed-lignin, benzyl ether and phenylcoumaran were susceptible to $\mathrm{AD}$ whereas $\beta-\mathrm{O}-4$, and resinol were resistant to anaerobic microbial degradation. Further optimization of SE pretreatment to increase the accessibility of lignin to $\mathrm{AD}$ is needed in future studies. On the other hand, the remaining undigested lignin-rich residues after AD that has less condensed-lignin structure and low carbohydrate impurity bears greater potential for further valorisation. Further research is needed to isolate the lignin-rich residues from the AD liquid. This study shows the benefits of using a combination of nylon bag techniques and advanced analytical techniques to study the degradation mechanisms of lignin during AD.

\section{Acknowledgements}

This study was financially supported by the Norwegian Research Council (Grant no. 243950, BioLiGas).

\section{References}

M. Langholtz, M. Downing, R. Graham, F. Baker, A. Compere, W. Griffith, R. Boeman, M. Keller. SAE International Journal of Materials \& Manufacturing, 7 115. 2014.

D. Stewart, Industrial crops and products, 27 202. 2008.

M. J. Taherzadeh, K. Karimi. International journal of molecular sciences, 9 1621. 2008 


\section{Glycerol, a By-product of Biodiesel Production for Value-Added Chemicals}

Christophe Len ${ }^{*, *}$

PSL Research University, Chimie ParisTech, CNRS, France

** Sorbonne Universités, Université de Technologie de Compiegne, France E-mail:

christophe.len@chimieparistech.psl. eu

\section{Introduction}

The design of environmentally friendly methodologies has been scientist's driving force in recent years. In particular, the use of biomass-derived materials, green solvents and alternative techniques have been investigated. In this regard, glycerol has the potential to be both an excellent renewable solvent in modern chemical processes and a versatile building block in biorefineries [1].

\section{Experimental}

\section{Oligomerization of glycerol in cyclic continuous flow stirred-tank reactor}

A mixture of glycerol (PG1, $240 \mathrm{~g} ; 2.61 \mathrm{~mol})$ and potassium carbonate $(10.0 \mathrm{~g}$, $72.4 \mathrm{mmol}$ ) were magnetically stirred and heated until complete dissolution of the base in a $250 \mathrm{~mL}$ glass beaker. The homogeneous mixture was pumped at a $1.0 \mathrm{~mL} \cdot \mathrm{min}^{-1}$ flow, using a peristaltic pump. After $300 \mathrm{~min}$, the reactor output was collected and yields of glycerol oligomers were determined by GC analysis with calibration curve.

\section{Gas chromatography analysis}

Gas chromatography analysis was performed on a PerkinElmer gas chromatography (Autosystem XL GC), using an Altech AT HT column, with a detector at $300^{\circ} \mathrm{C}$, an injector at $340^{\circ} \mathrm{C}$, and a constant flow of nitrogen of $\mathrm{mL} \cdot \mathrm{min}-1$. The column was heated at $150^{\circ} \mathrm{C}$ for $2 \mathrm{~min}$, and then warmed to $350^{\circ} \mathrm{C}$ with a temperature gradient of $15^{\circ} \mathrm{C} \cdot \mathrm{min}-1$ before being hold at that temperature for $4.67 \mathrm{~min}$. Each sample was derivatized before injection, according to the following protocol. Bis(trimethylsilyl)acetamide (BSA) $(0.5 \mathrm{~mL})$ was added to a sample $(40 \mathrm{mg})$ and the mixture was heated at $50^{\circ} \mathrm{C}$ for $30 \mathrm{~min}$. The solution was then diluted with $1 \mathrm{~mL}$ of ethyl acetate, and $1 \mathrm{~mL}$ was injected in the gas chromatography column. 


\section{Results and Discussion}

Several green chemistry approaches that target-advanced synthesis and processes using glycerol will be presented. Among the different examples, those that focus on the continuous oligomerization of glycerol in presence of potassium carbonate as homogeneous catalyst will be detailed (Figure 1) [2-3]. The different regioisomers of glycerol dimers and glycerol trimmers have been characterized and the distribution of the different oligomers has been quantified. Further investigations in a cyclic mode, combined with short path distillation, afforded a mixture of predefined glycerol oligomers with a distribution: glycerol dimer (20 wt\%), glycerol trimer (21 wt\%), glycerol tetramer (16 wt\%) and glycerol pentamer (11 wt\%).

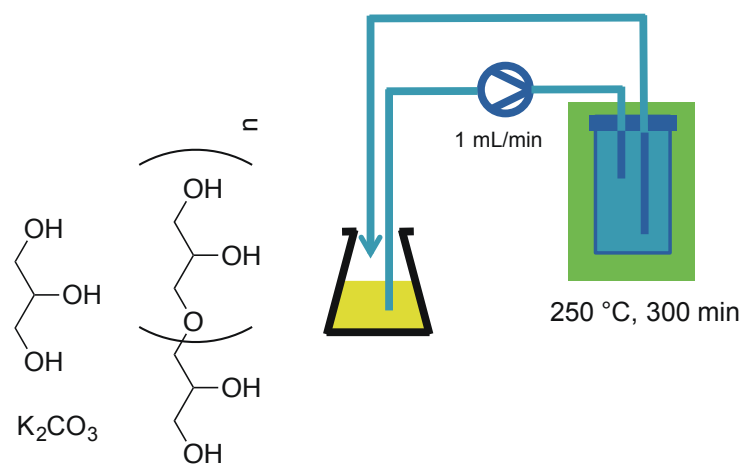

at $\mathrm{t}_{0}$, glycerol $(96 \mathrm{~g})$

$\mathrm{K}_{2} \mathrm{CO}_{3}(4 \mathrm{~g})$

Figure 1. Cyclic continuous flow stirred-tank reactor applied to glycerol direct polymerization on a hundred-gram scale of glycerol

\section{Conclusions}

A continuous flow stirred-tank reactor for the direct oligomerization of glycerol on a hundred-gram scale, using stainless steel $(100 \mathrm{~mL})$ and a peristaltic pump was successfully developed.

\section{Acknowledgements}

The author gratefully acknowledges the financial support of the European cosT Action FP1306 promoting networking and collaboration.

\section{References}

C. Len, F. Delbecq, C.C. Corpas, E.R. Ramos, Synthesis, 50 723. 2018.

N. Galy, R. Nguyen, P. Blach, S. Sambou, D. Luart, C. Len, J. Ind. Eng. Chem., 51 312. 2017.

R. Nguyen, N. Galy, A. Singh, F. Paulus, D. Stoebener, C. Schlesser, S.K. Sharma, R. Haag, C. Len, Catalysts, 7 123. 2017. 


\title{
Valorisation of Biomass through Low- Temperature Hydrothermal Transformations assisted by Photocatalysis
}

\author{
Juan C. Colmenares*, Vaishakh Nair*
}

Institute of Physical Chemistry, Polish Academy of Sciences,

Warsaw, Poland

E-mail:

jcarloscolmenares@ichf.edu.pl

\section{Introduction}

The aim of this lecture is to present the most recent state of the art on the development of novel methods for the transformation of lignocellulosic biomass sources into biofuels and valuable chemical precursors. The principal focus will be to discuss the pros and cons of a new approach, which consists of a hydrothermal process for biomass valorisation with new catalytic materials (e.g. based on supported semiconductor materials), which have excellent acid-base and photocatalytic properties. The objective is to decrease the reaction temperature and related energy expenditure limiting the unfavourable side products. This study will be performed thanks to the combination of heterogeneous photocatalysis, catalytic biomass valorisation and photocatalytic materials' synthesis [1-2]. The exploration of all resulting products formed in the gas and liquid phase -along with their selectivity according to the physicochemical, optical and acid-base properties of the involved materials- will give way to detailed knowledge needed to fully understand the new concept of biomass treatment's parameters and mechanisms. 


\section{Photo-thermocatalysis}

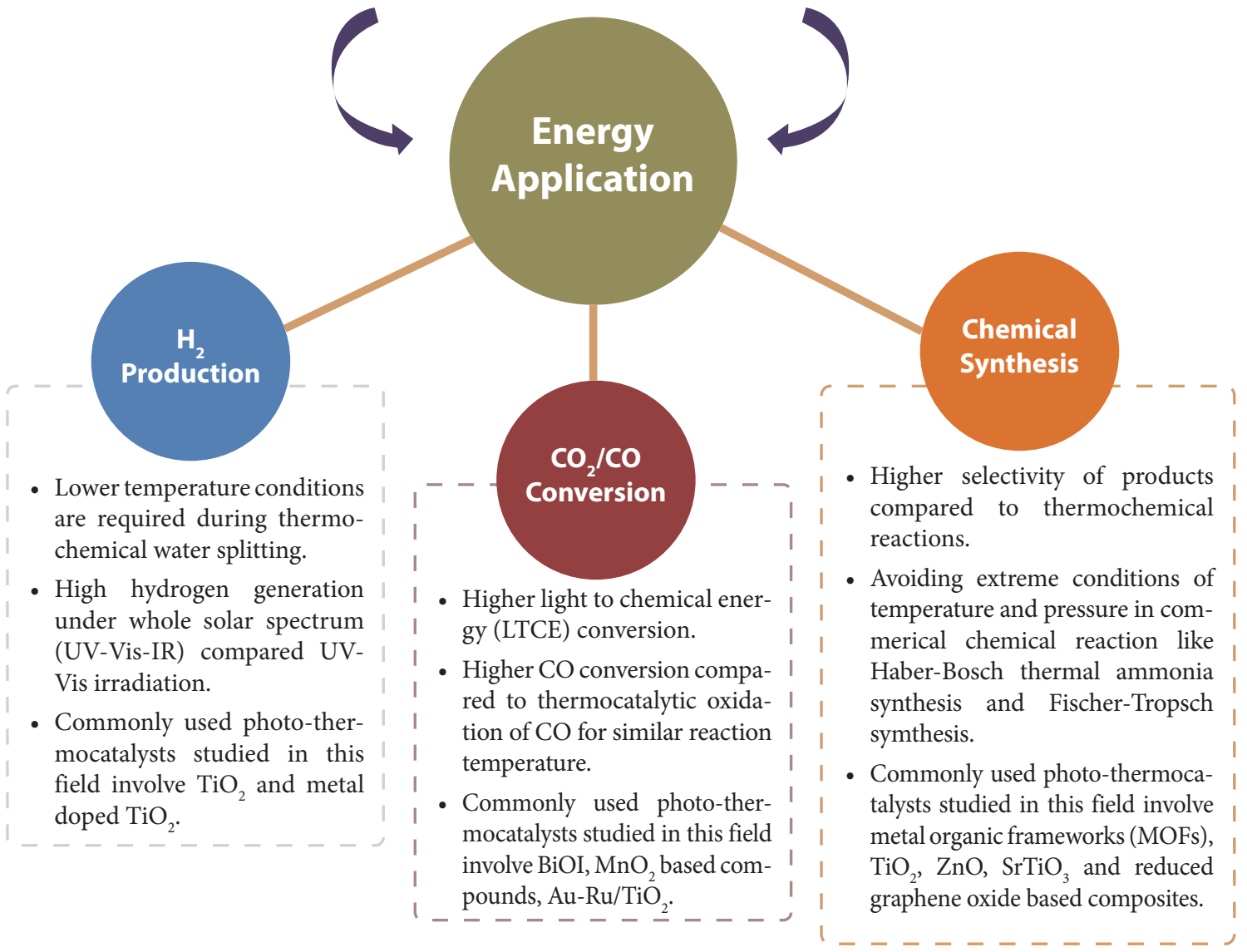

Figure 1. Photo-thermal catalysis for energy related applications

\section{Acknowledgements}

The authors acknowledge the partial support from the National Science Centre in Poland within Sonata Bis project no. 2015/18/E/ST5/00306 and opUs-13 project nr 2017/25/B/ST8/01592. The authors are also grateful for the Universidad Cooperativa de Colombia's invitation and for the support from cosT Action FP1306 promoting networking and collaboration.

\section{References}

J. Colmenares and R. Luque, Chem. Soc. Rev., 43 765. 2014.

S.-H. Li, S. Liu, J. Colmenares and Y.-J. Xu, Green Chem., 18 594. 2016. 


\title{
Integration of Biomass Products in a Traditional Oil and Gas Industry. The case of Ecopetrol
}

\author{
Edgar F. Castillo*
}

Instituto Colombiano del Petróleo, Empresa Colombiana de Petróleos, Colombia

E-mail:

edgar.castillo@ecopetrol.com.co

\section{Introduction}

Ecopetrol is a National Oil Company -NOC- focused on the reliable supply of fuels for the Colombian economy. Besides its traditional and conventional fossil-based products (gasoline and diesel), Ecopetrol has supported and promoted the National Biofuels program since 2005. Nowadays, the company produces bioethanol and biodiesel in two separated plants located in the Llanos Orientales region and in the company's main national oil refinery. In economic terms, currently the gasoline market share for bioethanol reaches about $10 \%$ and the biodiesel market share about $8 \%$. In addition, Ecopetrol follows the present global trends in energy, focused in achieving a global warming-motivated energetic transition. For this reason, the company has been carrying out a set of researches that aim to reduce the carbon footprint of its final products and promote the introduction of new biofuels to the market. The following graph illustrates the main results of this research program.

Biofuels research program at ECOPETROL. Main results

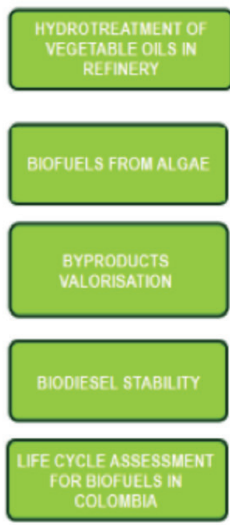

6 Patents granted

4 Technological Products

BioCetano 0 , Bioparafines, HDT

Heavy fractions

2 Patents Granted

2 Technological Products

2 Patents Granted

1 Technological Product

Production of organic biosolid from

vinasse

1 Patent Granted

1 Technological Product

Assesing of biodiesel-diesel blends

1 Technological Product

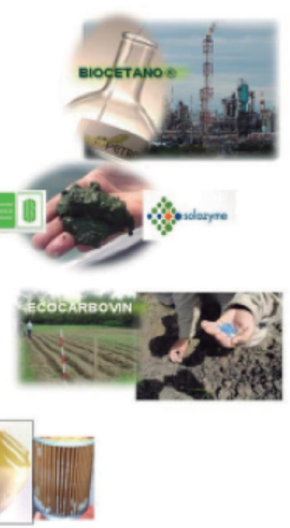

Figure 1. Biofuels research program at Ecopetrol. Main results 


\title{
Unlocking the Bioeconomy Potential of Latin America. Common Framework for the Assessment and Management of Sustainable Innovations (CASI-F): Methodology for Future Research on Sustainability
}

\author{
Rafael Popper ${ }^{\star},{ }^{* *},{ }^{* *}$, Monika Popper ${ }^{\star *}$, Guillermo Velasco ${ }^{\star *},{ }^{* *},{ }^{* * *}$
}

* VTt Technical Research Centre of Finland, Espoo, Finland.

* Futures Diamond, Manchester, United Kingdom.

*** University of Manchester, Manchester, United Kingdom.

***Universidad Politécnica de Madrid, Madrid, Spain.

E-mail:

rafael.popper@vtt.fi

\section{Introduction}

The aim of this paper is to introduce a methodology for future research on sustainability, which resulted from the development of the Common Framework for the Assessment and Management of Sustainable Innovations (CASI-F) [1], and its prospective use to unlock Latin America's bio-economy potential. With this in mind, the paper introduces the concept of bio-economy and highlights the growing need for sustainable pathways of production and consumption. What follows is the explanation of why CASI-F was developed and how can it be used to provide sound policy advice using a multi-level, multi-stakeholder and multi-systemic approach. Following a thorough literature review on existing sustainability frameworks [2-5], a need for a complementary approach that is more forward-looking and action-oriented, focusing specifically on increasing the sustainability of innovation and innovation-related processes was made evident. The CASI-F - a five-step approach to assessment and management of sustainable innovation (sI) - is then introduced and supported with an example of its application to a product innovation. The objective of the paper is to promote a more effective and holistic assessment of si. To do so, the paper shows the importance of the seven types of si researched, mapped and analysed (product, service, social, organizational, governance, system and marketing) in the EU funded CASI project. In addition, the paper discusses five systems (economic, social, environmental, government and infrastructure) that should be taken into account when assessing sustainable transformations and four types of critical issues or shapers of sI, namely: barriers, drivers, opportunities and threats.

CASI-F is a good example of a collective mobilisation and mutual learning process. CASI partners in $12 \mathrm{EU}$ countries (AT, BE, BG, CZ, DE, DK, FI, IT, PL, PT, SI, $\mathrm{UK})$, together with country correspondents in the other 16 member States and a network of 40+ innovators were engaged in the co-creation and crowdsourcing of solutions to critical issues raised by the Societal Challenge on Climate Action, Environment, Resource Efficiency and Raw Materials. The CASI-F methodology helped to promote the incorporation of science in society by integrating multiple knowledge sources and multi-stakeholder perspectives (including those of citizens and sustainability experts) for the assessment of critical issues and a better management of si that embraces societal concerns and needs. 
Finally, the paper presents the case of a forest-based bioeconomy (FBA) in Uruguay and demonstrates that the elements of the CASI-F framework supported: (1) the assessments of FBAs by mapping critical issues, needs, gaps, hopes and fears; (2) the mobilization of key players (government, business, research/education, civil society) to co-create a shared vision; and (3) the development of a roadmap for effective management of identified critical issues.

\section{References}

A. López, L. Mabe, B. Sanchez, C. Tapia and A. Alonso, "Best practice solutions: methods for sustainability assess- ment within the process industries." SAMT project report. Deliverable 2.1. (2015).

H. Pihkola, T. Pajula, C. Tapia, M. Ritthoff and R. Saurat, "Sustainability assessment methods and tools for cross-sectorial assessment." SAMT project report. Deliverable 3.1. (2016a).

H. Pihkola, T. Pajula and C. Tapia, "Future research needs and input for standardization." SAMT project report. Deliverable 3.2. (2016b).

R. Popper, G. Velasco and M. Popper, “CASI-F: Common Framework for the Assessment and Management of Sustainable Innovation." CASI project report. Deliverable 6.2. (2017).

M. Saurat, M. Ritthoff and L. Smith, "Overview of existing sustainability assessment methods and tools, and of relevant standards." SAMT project report. Deliverable 1.1. (2015). 


\title{
Case Study of R\&D\&I in a Pulp Mill to be integrated as a Forest Biorefinery
}

\author{
Alberto Coz ${ }^{\star}$, Tamara Llano*, Cristina Rueda*, Carlos Arce*, Gema Ruiz ${ }^{\star}$
}

Green Engineering and Resources, Department of Chemistry and Processes and Resource Engineering, University of Cantabria, Santander, Spain E-mail:

coza@unican.es

\section{Introduction}

Lignocellulosic waste materials can be valorised into several products including biofuels, additives, chemicals and others within the biorefinery concept. In this work, a new physicochemical laboratory in a sulphite pulp mill was built and the possibilities of new valorisation options from the spent sulphite liquor were studied at laboratory scale.

\section{Methodology}

The first step was starting up a new laboratory in a sulphite pulp mill in the north of Spain. Different equipment's for characterisation, hydrolysis and detoxification were added. Fermentation processes were carried out in other laboratories. Once the laboratory was built and all of the methods were obtained [1], the acid hydrolysis method was optimized in order to maximize the fermentable sugar in the spent liquor for valorisation options. In addition, a bibliographical review was conducted to study the best valorisation alternatives. The next step was to study different detoxification and/or separation alternatives in order to increase the valorisation alternatives in the pulp mill. Finally, taking into account the best separation methods and possibilities of valorisation, and the simulation of different alternatives at industrial scale, three integrated processes were recommended in order to transform the pulp mill into a new forest biorefinery.

\section{Results and Discussion}

- A new laboratory with all the equipment needed for hydrolysis and fractionation was built and the characterization of all of the main lignocellulosic materials in the entire process was carried out.

- The hydrolysis step of the pulp mill was optimized at laboratory scale, giving an increase of 30-35\% sugar content in the spent liquor [2] with similar pulp quality. 
- The main valorisation alternatives of the spent liquor were studied, not only from the hemicellulosic content, but also from the lignin point of view [3]. Lignosulfonates, phenolics, bioethanol, xylitol and furfural are recommended.

- Different unit operations were studied at laboratory scale in order to separate the main fractions [4-5], overliming, liquid-liquid extraction and anionic resins were the best options.

- Three different alternatives were recommended for a study at pilot and/or industrial scale. From the sugar content and taking into account the simulation of the entire process and the results at laboratory scale, xylitol or biopolymers are recommended as the best options [6].

\section{Conclusions}

The spent sulphite liquor can be valorised into different options from its hemicellulosic and lignin content, providing pulp and paper mills new market opportunities with the purpose of their transformation into forest biorefineries. In this work, three different alternatives have been proposed in a sulphite pulp mill.

\section{Acknowledgements}

The authors gratefully acknowledge the financial support of EUCAFUEL 23.H031.64003 research project under the framework of the Spanish Ministry of Science and Innovation and кввE-2012-6-311935 BRIGIT research project (www.brigit-project.eu), and the FP1306 and FP1205 COST actions from the UE.

\section{References}

T. Llano, N. Quijrona, A. Andrés, A. Coz, Biotechnology Reports, 15 75. 2017.

C. Rueda, J. Fernández-Rodríguez, G. Ruiz, T. Llano, A. Coz, Carbohydrate Polymers, 116 18. 2015.

C. Rueda, P.A. Calvo, G. Moncalián, G. Ruiz, A. Coz, Journal of Chemical Technology and Biotechnology, 90 2218. 2015.

T. Llano, N. Quijorna, A. Coz, Energies, 10348.2017.

T. Llano, M. Alexandri, A. Koutinas, Chr. Gardeli, H. Papapostolou, A. Coz, N. Quijorna, A. Andres, M. Komaitis, Waste and Biomass Valorisation, 61149. 2015.

C. Rueda, M. Marinova, J. Paris, G. Ruiz, A. Coz, Journal of Chemical Technology and Biotechnology, 91 2646. 2016. 


\section{Chatbots, Artificial Intelligence, Natural Language processing and Deep Learning in the Energy Field}

Fernando Macho Hernantes*

Universal Health Services, S.l. and Medwhat.com, Leioa Bizkaia, Spain and Palo Alto, Stanford, USA

E-mail:

fernando.macho@medwhat.com

\section{Introduction}

How can last generation chatbots with artificial intelligence, natural language processing and deep learning help the energy industry nowadays?

\section{Chatbots and virtual assistants in the energy industry}

Customer care in energy companies still relies on call centres and live chat support; which means it's a one to one play. As energy companies gain more customers, there are high chances that the volume of customer inflow will overwhelm the customer care agents available. The same happens during non-working hours. Thus, energy companies face a crucial issue: the inability to cope with customer queries.

Chatbots are built to handle customer queries. Most queries have the same answer with variations depending on the customer's semantics or slangs. Thus, a chatbot trained with machine learning and Recurrent Neural Network (RNN) can identify and group questions with similar intent. This resolves lots of queries in an instant. Grouping questions instead of having them scattered increases the odds of solution. The chatbot can be trained on the FAQ and previous customer logs to address repetitive or easy-to-resolve concerns. Email support can be automated the same way to address repetitive scenarios, thereby generating quicker responses.

Energy companies could also add new tariffs to the menu part of the chatbot so that it's easy to send meter reading. Other usual jobs can also be performed such as requesting a call back from the appropriate department. Two of the main inconveniences customers face are: 1) being transferred back and forth to different departments and 2) having to wait long hours. By identifying the intent, the appropriate department might take the call back or connect the customer via live chat to address the issue. Chatbots can also be used actively to show off new tariffs that may be beneficial to customers.

When customers receive a flawless care experience, they are most likely to spread the word in their social circles. This acts as advertising for energy companies. 


\section{Discussion topics:}

- Applications of artificial intelligence in the energy industry

- Natural language processing in the energy industry

- Deep learning in the energy industry

- Examples of use

\section{Conclusions}

The use of these technologies and the application of artificial intelligence, natural language processing and deep learning in the energetic industry, is indispensable for its better optimization and efficiency. 


\title{
Aquatic Renewable Energy Potential in Colombia
}

\author{
Natalia Rojas*, Ramón F. Colmenares-Quintero ${ }^{\star *}$
}

* Aquatera Ltd.

** Universidad Cooperativa de Colombia, Colombia E-mail: natalia.rojas@aquatera.co.uk

\section{Introduction}

Through the project "Identification of Knowledge Gaps in the Academy and Capacity for Building Aquatic Renewable Energy in Colombia”, the Universidad Cooperativa de Colombia (UCC; https://www.ucc.edu.co/Paginas/inicio.aspx), The International Centre for Islands Technology (ICIT; https://www.hw.ac.uk/schools/ energy-geoscience-infrastructure-society/research/iles/icit.htm) and Aquatera (https://www.aquatera.co.uk/) collaborate to develop an assessment of the state of the art and to map the aquatic renewable energy resource potentials in Colombia, including floating, solar, offshore, wind and in-river hydrokinetic (RH). The project is funded by the Royal Academy of Engineering (https://www.raeng.org.uk/); which aims to support knowledge exchange between Colombian and uK businesses and academy to develop a capacity building programme for teaching and researching about this emerging industry in Colombia.

\section{Experimental}

The team mapped the floating solar resource onshore, in natural and artificial water reservoirs and offshore, assessing areas with solar potential, low wave and tidal activity and coastal community's nearby. The onshore floating solar potential was evaluated using the solar resource $\left(\mathrm{kWh} / \mathrm{m}^{2} /\right.$ day $)$ inland together with water reservoirs and settlements. The offshore floating solar potential was calculated using a model from the onshore solar resource extrapolated to offshore, together with the identification of areas with low wave and tidal forces, as well as niche markets close by. An analysis of the offshore wind resource in the Caribbean region of Colombia, together with the bathymetry led to the identification of areas for pilot and commercial projects linked to several niche markets such as the oil and gas sector in Colombia. The RH potential in the country needs specific river data not available in some areas, the assessment has focused on using existing facilities such as channels, hydroplants, etc., as potential sites for the deployment of these river technologies. The wave and tidal energy resources along the Colombian coast was mapped by the Research Group in Oceanography and Coastal Engineering, Oceanicos (https://minas.medellin.unal.edu.co/gruposdeinvestigacion/oceanicos/ oceanicos.html) of the Universidad Nacional de Colombia in Medellín. 


\section{Results and Discussion}

The assessment of the floating solar onshore and offshore potentials in Colombia identifies three inland areas with grid infrastructure and available artificial water reservoirs, a solar resource of $305.93 \mathrm{~W} / \mathrm{m}^{2} /$ day, as well as niche markets. The modelled data available suggests that average wind speeds approach the threshold of $8.3 \mathrm{~m} / \mathrm{s}$ ( 16 knots), considered attractive for offshore wind projects in several areas.

The team assessed the $\mathrm{RH}$ resources potential in Colombia. A key market for RH technologies of existing hydropower facilities could appear. Turbines installed downstream of hydroelectrics, or previously non-electrified dams, provide a means for rapid and cost-effective power output boosting without having to construct civil works or interfering with the dam's operation. Arrays located downstream of dams are likely to benefit from improved grid access, improved ease of gaining consent and reduced conflict potential with other river users, as well the protective features of the dam against debris and flooding. The region of Colombian's central, oriental and occidental mountains has the highest hydrokinetic potential, but it is crucial to gather local data. The exit of existing hydro plants are also suitable locations for hydrokinetic projects, together with floating solar projects in the water reservoir.

Wave modelling of the Colombian Caribbean coast showed higher values during the summer season (December, January and February), ranging around $5-7 \mathrm{~kW} / \mathrm{m}$; in such periods of time there is less over Colombian territory and so water levels decrease. Conversely, during rainy seasons (September, October and November), the mean wave-power values reach $1 \mathrm{~kW} / \mathrm{m}$. In the Colombian Pacific coast, the maximum wave power is close to half of that one estimated for the Caribbean Sea, about 2-3 kW/m, however this is an average that does not work for the June, July and August trimester, when the wave resource is less abundant. Tidal energy was estimated by Oceánicos with a simulation model called H2D, using bathymetry data from NOAA ETOPO and wind data from Global Reanalysis 1 Project. The results show that the mean current speeds for Buenaventura Bay and Malaga Bay are clustered around $0.8 \mathrm{~m} / \mathrm{s}$. The places with maximum power show values between $100 \mathrm{~W} / \mathrm{m}^{2}$ (ebb tide) and $250 \mathrm{~W} / \mathrm{m}^{2}$ (flood tide). In the San Juan delta there are some places with more power potential, however the sediment transport will affect the overall feasibility. The highest power could yield a maximum power supply close to $8.1 \mathrm{MW}$ for Buenaventura Bay; nevertheless, the simulated speed is very low compared with places with possible future commercial developments that have current speeds around $2 \mathrm{~m} / \mathrm{s}$, equivalent to about $960 \mathrm{~W} / \mathrm{m}^{2}$.

\section{Conclusions}

The most interesting proposition to deploy floating solar systems consist of water reservoirs, where power can be generated while reducing evaporation losses. Municipal water treatment facilities, hydroelectric reservoirs are just two examples of existing infrastructure installations with grid connections where floating solar systems and hydrokinetic technologies could generate electricity close to power demand whilst reducing water loss.

The offshore wind industry is growing rapidly internationally and as costs come down, fixed and floating offshore wind systems are becoming more competitive. Colombia has a high wind resource in the Caribbean regions with different depths available for different types of projects.

River hydrokinetic is an emerging technology sector in which electricity-generating technologies are placed directly in the river flow without creating any artificial head or water or piping being a potential low-impact alternative. The sector has an undoubted potential in Colombia.

Although Colombia's wave and tidal resources have been modelled, the number of sites where real measurements have been taken is limited and it would be useful if longer term tidal and wave resource data could be measured. According to the information available for this preliminary study, the marine energy resources potential in Colombia is not as high as in other countries but enough for small or medium scale projects.

\section{Acknowledgements}

Royal Engineering Academy.

\section{References}

A. Osorio, S. Ortega, Renewable and Sustainable Energy Reviews, 53 966. 2016. 


\title{
Renewable Energy Solutions for Off-grid Zones
}

\author{
Ramón F. Colmenares-Quintero ${ }^{\star}$, Luis F. Latorre-Noguera ${ }^{\star}$, Natalia Rojas $^{\star \star}$, Karl Kolmsee ${ }^{\star \star \star}$, \\ Gina Maestre-Góngora*
}

\footnotetext{
Universidad Cooperativa de Colombia, Colombia

** Aquatera Ltd., UK

*** Smart Hydro Power, Germany E-mail:

ramon.colmenaresq@ucc.edu.co
}

\section{Introduction}

The indigenous community of Kanalitojo is located 25 kilometres away from the municipality of Puerto Carreño, in the state of Vichada in Colombia. This community's population includes three indigenous tribes: Sáliva, Amorúa and Sikuani. All tribes currently count with a total of 163 people grouped in approximately 33 families, located in an extension of 573 hectares approximately. 93 women and 70 men make up this population. The problem of the community is a lack of technological alternatives for energy generation to support their daily life. The main causes of this difficulty are its nomadic and semi-nomadic character that leads them to change their location depending on the productive period of the crops they grow and consume. This has affected the development of other types of provisional solutions and additionally, comprises a challenge: to think of alternatives for energy generation and/or supply.

\section{Methodology}

To carry out the analysis of energy solutions for the community, four approaches were defined where different energy technologies were combined. These solutions must adjust to the geographical, social and cultural conditions of the Kanalitojo community. Each of these solutions was simulated using the Trnsys V17 software and in-house models under the same energy demand and operating conditions. The outcomes of energy generation obtained by the software were compared with a simple cost analysis taking into account the installation costs. After the technical and economic calculations we proceeded to select the solution that provides the best cost-benefit ratio.

The first solution includes the use of individual solar panels for each of the 18 houses and the use of a hydrokinetic turbine located in the Meta river, which would be in charge of supplying electricity for refrigeration, industrial and educational centres, or so-called distribution centres. The second proposed solution refers to the use of a single hydrokinetic turbine installed in the Meta river. It would be in charge of supplying the necessary energy for the 18 houses and for the distribution centres above-mentioned, through a distribution network that 
would transmit the energy generated to the entire consumption network. The third proposed solution includes the use of a hydrodynamic turbine installed in the Meta river along with an array of solar panels that would direct the energy generated to a power station where the community members could charge their portable batteries for domestic use; likewise, the power station would supply electricity for refrigeration, industrial and educational centres (see Figure 1).

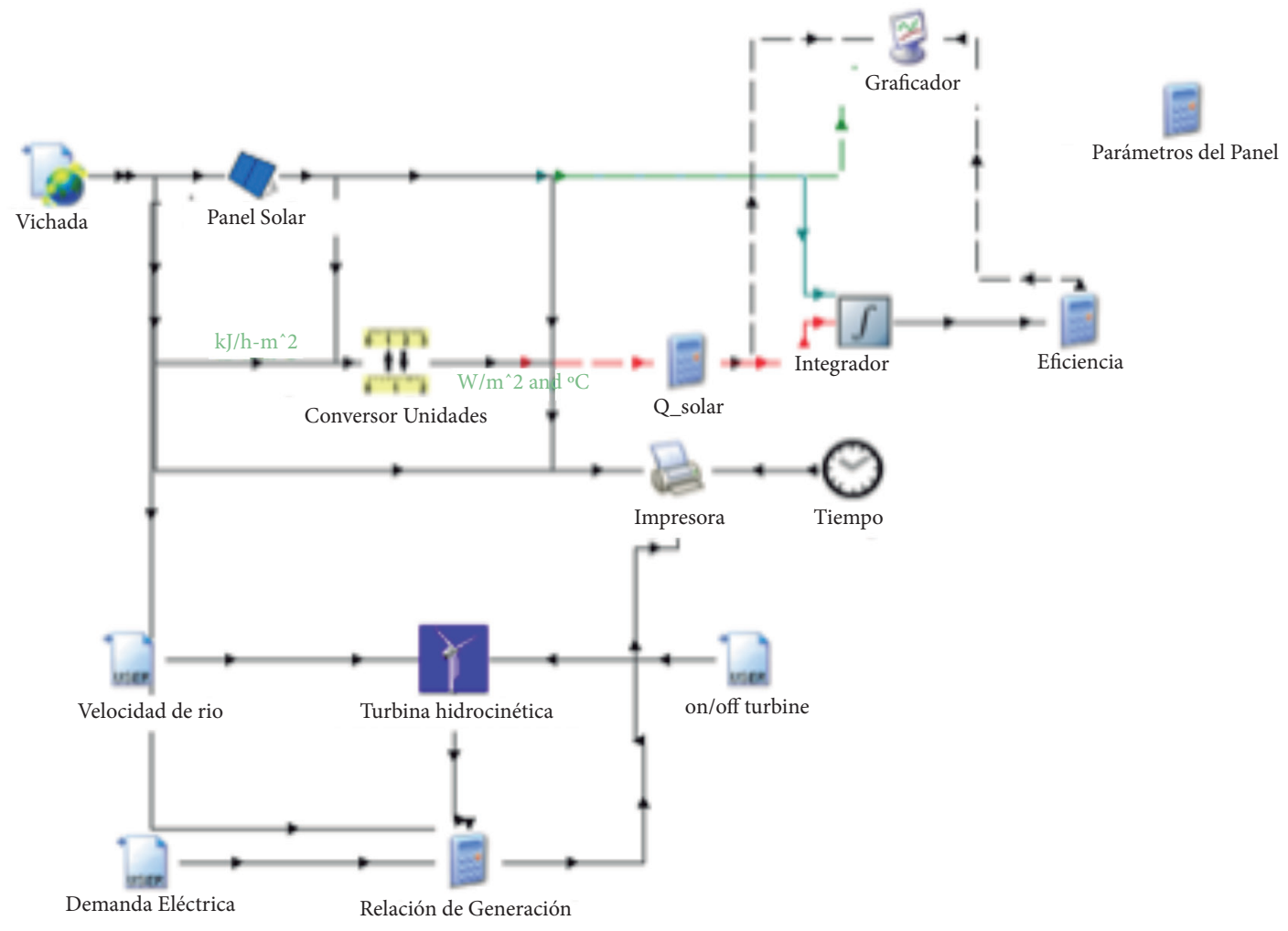

Figure 1. Trnsys simulation for solution 3

The fourth solution considered in this study refers to the use of a micro-cogeneration unit linked to a bio-digester, which uses the organic waste generated in the different agricultural activities of the community for the production of biogas to feed the internal combustion engine. The energy produced will go to a reception plant that will send electricity for refrigeration, educational and industrial centres and that will serve as the charge point for the portable batteries of each family.

\section{Results and Discussion}

Table 1 shows the comparison between the demanded and generated energy for each simulated solution. It is important to keep in mind that the energetic demand for each solution varies, but it does not modify the conditions of demand of each one in comparison with the others. 
Table 1. Comparison of demand and energy generation per solution

\begin{tabular}{|c|c|c|c|}
\hline Solution & $\begin{array}{c}\text { Energy } \\
\text { Reque- } \\
\text { riments } \\
(\mathrm{MWh})\end{array}$ & $\begin{array}{c}\text { Energy } \\
\text { Generation } \\
(\mathrm{MWh})\end{array}$ & $\begin{array}{c}\text { Difference } \\
(\mathrm{MWh})\end{array}$ \\
\hline 1 & 4.57 & 10.71 & 6.14 \\
\hline 2 & 9.23 & 10.37 & 1.14 \\
\hline 3 & 8.39 & 18.80 & 10.41 \\
\hline 4 & 8.39 & 7.47 & -0.91 \\
\hline
\end{tabular}

\section{Conclusions}

After carrying out the analysis of the proposed solutions, it was found that the use of solar panels and a hydrokinetic turbine combined with the use of portable batteries provides the greatest guarantee in energy supply with relatively low costs.

\section{Acknowledgements}

This work was sponsored by the Universidad Cooperativa de Colombia under the research project "Environmental and Techno-economic Evaluation of Micro-cogeneration Systems from Biomass", it provided all the necessary tools and equipment, as well as the funds that allowed us to develop this project. We also thank the Group "Catalysis for Sustainable Energy Production and Environmental Protection" of the Institute of Physical Chemistry of the Polish Academy of Sciences and the Norwegian Institute of Research in Bioeconomy for their contributions and observations in the development of this research. The support of Action FP1306 of the cosT scientific network (European Cooperation in Science $\&$ Technology) is also recognized.

\section{References}

C.M. Zapata, B. Singh, M.M. Zuluaga, I. Dyner, Energética, 3455 (2005).

E. Searcy, P.C. Flynn, Biomass and Bioenergy, 34798 (2010).

L. G. Ricardo, Y. Venecia, "Evaluación del Recurso Eólico en Colombia para su Aprovechamiento como Fuente de Energía Eléctrica Caso de Estudio: Galerazamba (Bolívar).” Pre-Degree, Cartagena University, Cartagena de Indias, 2011.

C. Franco, I. Dyner, S. Hoyos, Dyna, 75199 (2008).

J. H. Flórez, D. Tobón, G. A. Castillo, Cuadernos de Administración, 22219 (2009).

T. Jiménez, Energética, 4493 (2014). 


\section{Strategic Plan Advances of the National Marine Sciences and Hydrobiological Resources Program}

Argiro de J. Ramírez ${ }^{*}$

National Program of Science, Technology and Innovation in Marine Sciences and Hydrobiological Resources. Colciencias, Bogotá, Colombia E-mail:

adjramirez@colciencias.gov.co

\section{Strategic Plan 2018 - 2028. Aims and purpose}

The National Marine Sciences and Hydrobiological Resources Program aims to understand the high complex and multiscale socio-ecological systems and services. By means of technical scientific studies; which span from simple observations to advanced multi-disciplinary research, the program seeks the projection and use of the produced knowledge for the following:

1. Understand the processes involving water bodies, soil and atmosphere, and the dynamics between the marine and fluvial environment, affected by physi$\mathrm{cal}$, chemical or other processes related to changes between the aquatic biomes and the climate system.

2. Understand life and its chemical and physical processes, beginning with its different biological organisation levels, from a molecular to an ecosystem level.

3. Identify the marine and continental waters renewable resources that potentially have a sustainable use, including those necessary to guarantee food security and those relevant to biotechnological processes. Likewise, to evaluate the economical strategic use of hydrobiological systems as sources for sustainable development.

4. Examine the state of the resources being used at present. Identify the potential resources suitable for sustainable use. Recognise the limits, economical value and correct management of the socio-ecological systems related to the aforementioned exploitation and extraction activities.

5. Understand the economical and sustainable exploitation assessments of marine and fluvial non-renewable resources, prioritizing the identification and use of alternative energy sources.

6. Understand the natural and anthropic stressing factors on aquatic environments, as well as their impacts and effects on these socio-ecological systems. Identify preventive actions for the mitigation and recovery of the environmental quality of marine and continental water bodies.

7. Develop the marine sciences, hydrology, and maritime and fluvial industries by means of the creation, design, construction and use of equipment and systems. Identify the use of marine organisms, genomes or derived products for the socio-ecological systems' benefit. 
8. Identify threats and risks in fluvial, marine and coastal areas to implement mechanisms that prevent or minimize impacts.

9. Create maritime and fluvial awareness in the Colombian population by means of a social appropriation of knowledge.

10. Transform scientific knowledge into decisions for the sustainable management of the marine-coastal and fluvial environment.

\section{Fundamental current discussions, concepts and theories}

- The effects of climate change

- The current state and management of economically relevant ecosystems and resources

- The degradation, contamination and reduction of water resources

- Alternative energy from oceanic and continental water body resources

- The increased conflict due to marine-coastal and continental waters' use 


\title{
Use of Autonomous Drones for Monitoring, Surveillance and Security
}

\author{
Daniel Portnoy*
}

Consultech Israel, Consultech Colombia

E-mail:

yportnoy@inter.net.il

\section{Introduction}

Numerous applications require aerial monitoring and surveillance. Among many examples of such uses, there are civilian applications for monitoring forest fires, precision agriculture and tracking wildlife; surveillance applications for monitoring oil fields, pipelines and private neighbourhoods; in homeland and military security for the surveillance of military installations and border patrol; or for monitoring the perimeter of nuclear power plants and searching for illegal crops. The use of single-manned vehicles for surveillance has many disadvantages. Typically, large and expensive equipment, hazardous environments and operator fatigue can potentially threaten the life of the pilot. Therefore, there is a critical need for automating aerial surveillance using Unmanned Air Vehicles (UAVs). This paper gives an overview of a cooperative autonomous control strategy for aerial monitoring and surveillance with uAvs. There are many approaches for cooperative control problems. One of them is the Decentralized Cooperative Aerial Surveillance; which will be used as an example of cooperative control strategy, due to its similarity to our approach.

According to previous reports [1], this approach can be summarized in four steps: (1) the definition of a cooperation constraint and cooperation objective; (2) the definition of a coordination variable as the minimal amount of information needed to effect cooperation; (3) the design of a centralized cooperation strategy; and (4) the use of consensus schemes to transform the centralized strategy into a decentralized algorithm. Despite the wide use of this methodology, our study is based on an Artificial Potential Field (APF) approach. According to the principle of APF [2], the movement of the UAV in a real environment is regarded as a movement in a virtual force field. The target point attracts the UAV and the obstacle excludes it. The vector sum of the two is the resultant force of UAV in the potential field, hence the control over the UAV movement and direction. In order to show the results of our strategy, we prepared some video simulations in different scenarios. 


\section{Simulations Using an Autonomous Drone Squadron}

We performed four simulations using aun autonomous drone squadron for different applications, such as: surveillance and security of a close condominium neighbourhood, monitoring a planted field, surveillance and security of a gas pipeline, and monitoring for possible illegal logging. The results of those simulations were recorded to describe the system's response to events occurred in these scenarios.

\section{Results and Discussion}

The simulations' results depicted in the videos show the drone squadron acting as a team. However, in autonomous mode, it displays a quicker response and better coverage whenever an unexpected event occurs during a typical scenario.

\section{References}

R. Beard, T. McLain, D. Nelson, D. Kingston, D. Johanson, Proceedings of the IEEE, 2006, pp. 1306.

X. Zhang, X. Hao, G. Sun, Y. Xu, China Satellite Navigation Conference (CSNS) 2017 Proceedings, 2017, pp. 473 
Short Presentations' Abstracts 


\section{Awards}

The best summaries will be considered for a special issue in:

* cogent engineering

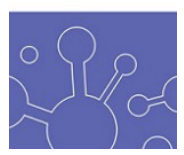

Cogent Engineering Journal (indexed in ISI-Scopus). Publisher: Taylor and Francis, United Kingdom. These articles must follow the journal's editorial guidelines.

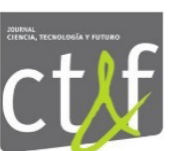

CTङF Journal - Ciencia, Tecnología y Futuro (indexed in ISI-Scopus), Journal of Technology, Science and Future. Ecopetrol S.A. Edited by the Instituto Colombiano del Petróleo (ICP). 


\title{
Valuation of Coffee Pulp applying the Biorefinery concept to produce High Value-Added Phytochemicals, Syngas and Methanol
}

\author{
Carlos E. Aristizábal*, Andrés F. Vargas*, Pedro N. Alvarado*
}

Instituto Tecnológico

Metropolitano, Medellín, Colombia E-mail:

carlosaristizabal207157@correo.

itm.edu.co

\section{Introduction}

Biorefineries offer a path towards a more sustainable production by valorising wastes and using renewable resources [1-2]. This allows nutrient recovery to produce fertilizers by extracting high added-value phytochemicals (e.g., caffeine, polyphenols, and saponins, etc.) [1,3-4]. Such waste is later used as a source of electrical energy, fuels and/or chemicals in general (methanol), by means of thermochemical treatments (gasification). In Colombia, few industries have adopted this concept and have incorporated the recovery of fine chemicals found in biomass in their value chain. The reason behind has to do with their relatively low content of raw vegetable material [5]. Furthermore, if energy in second-generation biomass is not efficiently recovered to obtain other functional products and is employed as fertilizer or low-quality fuel [5-8], all its potential for adding value is wasted and this becomes an environmental issue [9].

The aim of this study is to propose a modular scheme process to implement in a biorefinery for the valuation of coffee pulp. The first step consists of a chlorogenic acid (CGA) solid-liquid solvent extraction stage, followed by a gasification of residual pulp to produce syngas. Finally, this gas is turned into methanol as a fuel product or platform molecule [10] using a catalytic packed-bed reactor and $\mathrm{Cu} / \mathrm{ZnO} / \mathrm{Al}_{2} \mathrm{O}_{3}$ as catalyst. Figure 1 shows the proposed biorefinery scheme. 


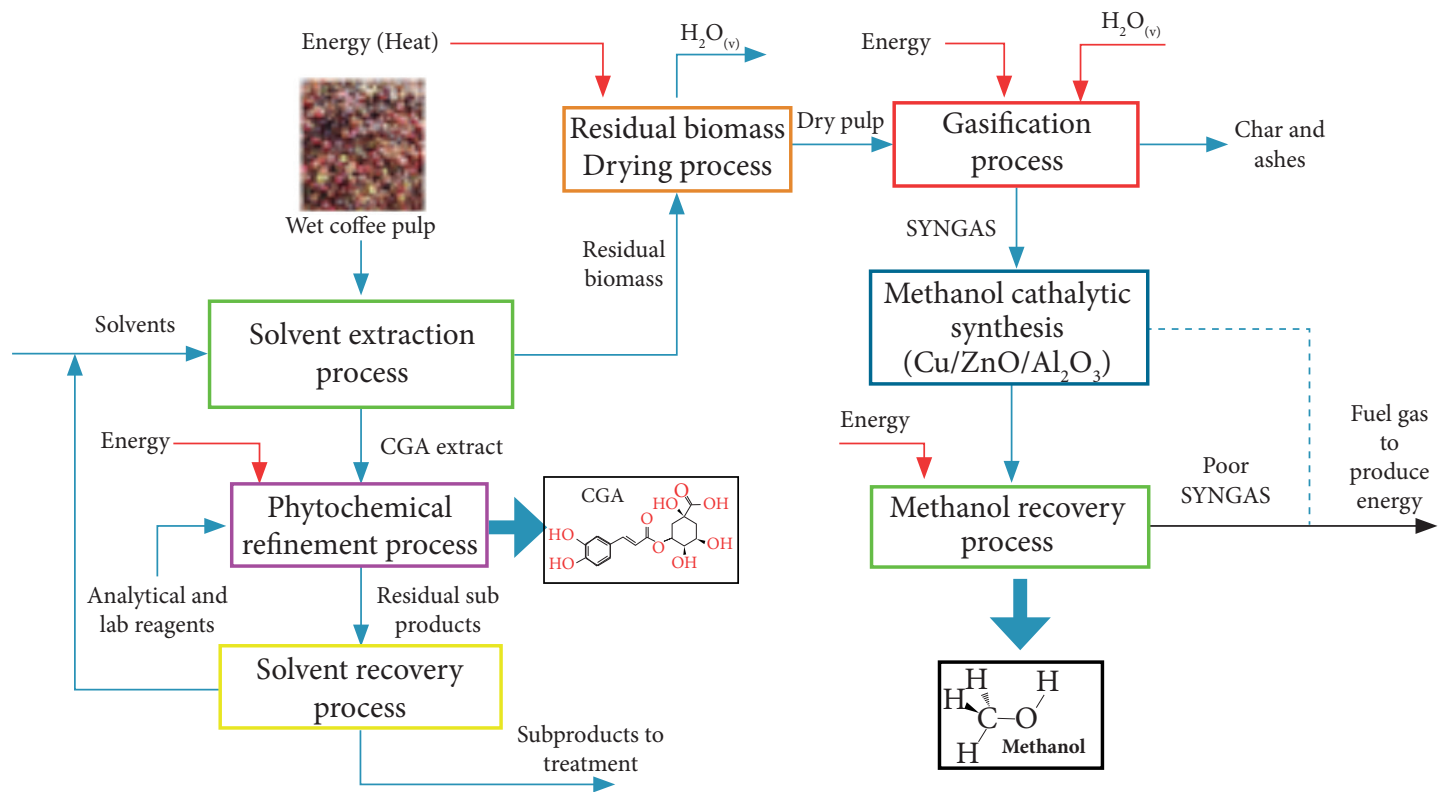

Figure 1. Proposed biorefinery scheme

\section{Experimental}

In previous research, a numerical and analytical methodology to select the correct solvent to extract complex phytochemicals based on contribution group methods, the Hansen Solubility Parameters,
Human Health and environmental risk assessment and sustainable and economic criteria were developed [11-12]. Later, the methodology extended to evaluate solvent mixtures too.T5. Figure 2 shows the improved methodology in the left side, and the results for the CGA case in the right side.
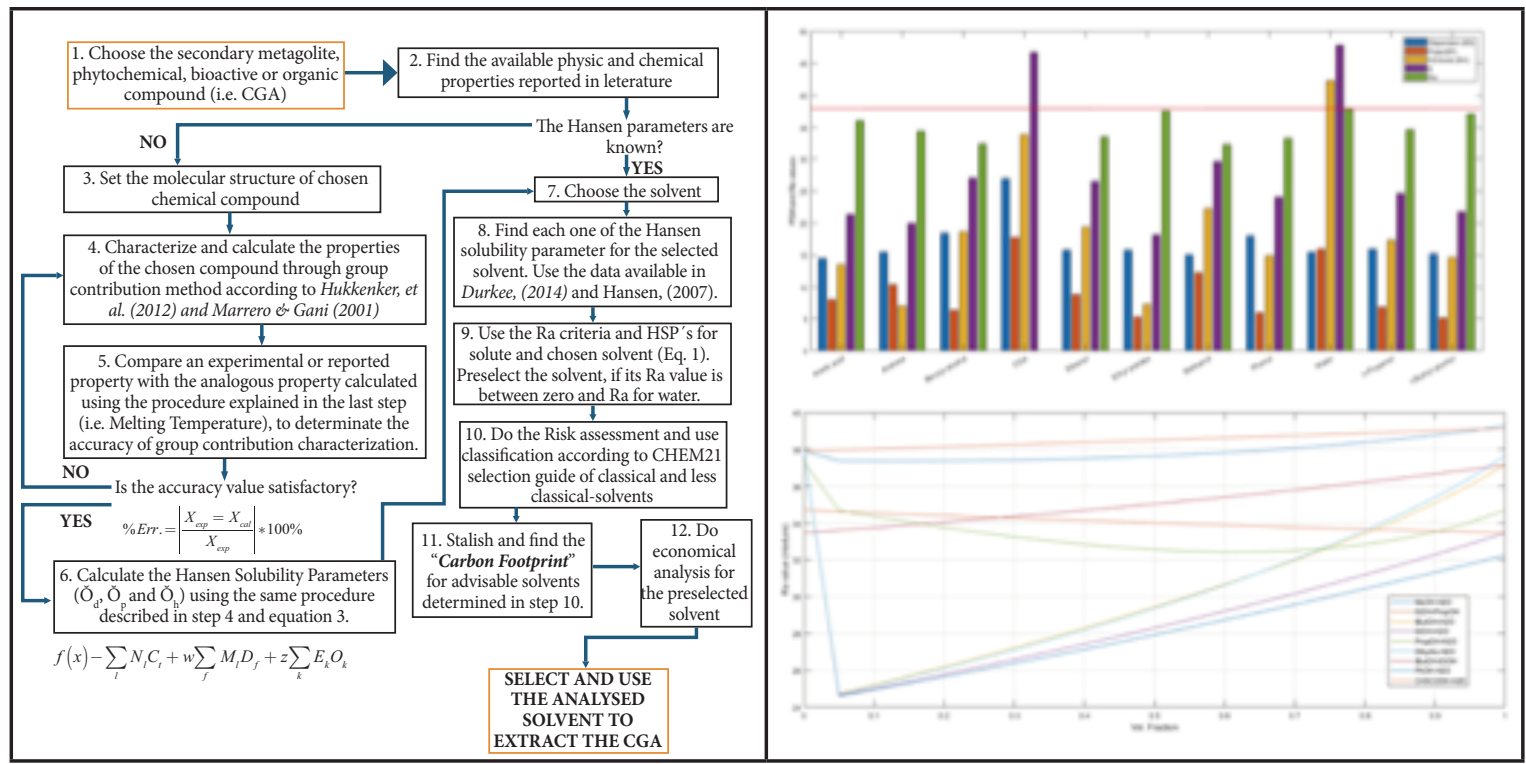

Figure 2. Solvent selection methodology and results for CGA case 
The improved methodology was applied to the CGA, a high-added value chemical [13]. The results show that pure water would be the best extraction solvent, followed by ethanol and an ethanol/aqueous solution. The extraction was carried out taking $125 \mathrm{~g}$ of dry residual biomass and mixing it with deionized water, pure ethanol or an aqueous solution with a ratio of 70:30 v/v ethanol: water. The extraction process of coffee pulp with water was affected by microorganisms, meanwhile the extraction with an ethanol aqueous solution was not attacked by them and displayed an increased stability. For that reason, water extract was avoided, and due to economic criteria, the $70: 30 \mathrm{v} / \mathrm{v}$ ethanol: water solution was selected as extraction solvent.

Fresh pulp and residual pulp were analysed in a Leco Truspec Micro CHNs equipment to find their elemental composition according to ASTM D5373. Then, these two types of biomass were gasified using a horizontal oven reactor, heated by electrical resistances and controlled wirh a PID device. The syngas gases were analysed with a MicroGC Agilent model 3000 and detected by two TCD. The CHN char composition was determined using Exeter Analytical CE 440 device and following the ASTM D5373, the ashes were characterized according to ASTM D3173 and the pulps Heat Value were found using ASTM D5965.

The methanol production using syngas as raw material in a packed-bed reactor with $\mathrm{Cu} / \mathrm{ZnO} / \mathrm{Al}_{2} \mathrm{O}_{3}$ was simulated in Matlab ${ }^{\circledR}$ considering the chemical kinetics mechanism proposed by Vanden Bussche and Froment [14] for pressure drop and catalyst deactivation.

\section{Results and Discussion}

Table 1 shows the elemental analysis results for the fresh and residual pulp after an extraction process. Otherwise, table 2 shows the calorific value results for both samples.

Table 1. Elemental analysis results. (\% p/p wet basis)

\begin{tabular}{|c|c|c|c|c|}
\hline Sample & N & C & H & O \\
\hline Pulp & 2.5 & 39.1 & 5.2 & 41.7 \\
\hline Pulp (70-30) & 2.3 & 40.1 & 5.4 & 43.2 \\
\hline
\end{tabular}

Table 2. Gross calorific value (J/g)

\begin{tabular}{|c|c|c|}
\hline \multirow{2}{*}{ Sample } & \multicolumn{2}{|c|}{ Calorific value } \\
\cline { 2 - 3 } & $\mathrm{cal} / \mathrm{g}$ & $\mathrm{J} / \mathrm{g}$ \\
\hline Pulp & 3733.33 & 15631.00 \\
\hline Pulp (70-30) & 3798.00 & 15903.00 \\
\hline
\end{tabular}

According to these results, the thermal properties of the pulp are enhanced once it passes through the phytochemical extraction process.

Table 3 shows the syngas composition of pulp gasification process, varying the pulp type, temperature and steam/biomass ratio. The $\mathrm{H}_{2} \mathrm{~S}$ concentration is not shown, because the results are close to zero.

Table 3. Syngas composition and gasification conditions

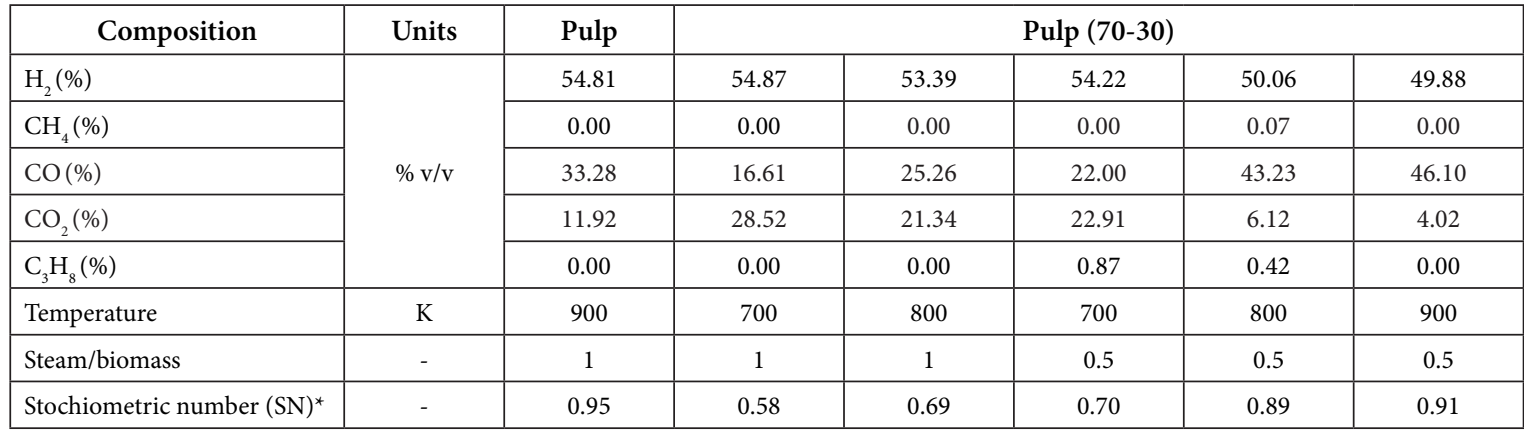

*The efficiency and performance in the methanol synthesis process is favoured for SN values close to 2, with the optimum value being $2,05[10,15-16]$ effects on electricity production due to heat pump integration or district heating (DH) 
The methanol production from coffee pulp is pending. But, in a previous research [17], the algorithm was validated and evaluated for several types of residual biomass in terms of process temperature and other operational conditions like S/B ratio.

\section{Conclusions}

Biorefinery is an alternative to transform biomass, i.e. agro-industrial wastes into valuable products such as fine chemicals, fuel, food, energy, etc. Generally, they process the entire biomass matrix through thermochemical and biological treatments. Few studies in this field consider a phytochemical extraction process from residual biomass. The biorefinery method proposed here consists of three stages: phytochemical extraction from coffee pulp, followed by a gasification stage and finally, a methanol catalytic stage.

According to the results, the proposed biorefinery is a multi-product installation because it produces two traded compounds: CGA and methanol. The extraction stage was best using an ethanol aqueous solution (70/30 $\% \mathrm{v} / \mathrm{v}$ ) to extract the $2,4 \% \mathrm{p} / \mathrm{p}$ (dry basis) of CGA content in pulp (according to [18]). The extraction stage enhances the calorific value of the residual pulp and favours the thermochemical treatment.

\section{Acknowledgements}

The author thanks Iтм for the economic and technological support and Carlos Aristizábal is also grateful to Sapiencia for the half-scholarship received by the program "Extendiendo Fronteras".

\section{References}

D. E. Carey, Y. Yang, P. J. McNamara, and B. K. Mayer, Bioresour. Technol., 215186 (2016).

C. Aristizábal, La Tekhné, 8811 (2016).

P. Esquivel and V. M. Jiménez, Food Res. Int., 46488 (2012).

P. S. Murthy and M. M. Naidu, Resour. Conserv. Recycl., 66 45 (2012).

A. Lapkin, E. Adou, B. N. Mlambo, S. Chemat, J. Suberu, A. E. C. Collis, A. Clark, G. Barke., Comptes Rendus Chim., 17232 (2014).

T. Salinas, T. Sánchez, M. E. Ortega, M. Soto, A. Díaz, J. Hernandéz, C. Nava, H. Vaquera, Rev. Bras. Zootec., 43492 (2014).

M. T. Torres-Mancera, J. Cordova-López, G. RodríguezSerrano, S. Roussos, M. A. Ramírez-Coronel, E. FavelaTorres and G. Saucedo-Castañeda, Food Technol. Biotechnol, 49369 (2011).

J. M. Bilhate. Chala, S. Latif, "Management of land use systems for enhanced food security: conflicts, controversies and resolutions", in Conference: Tropentag.

S. R. Hughes, J. C. López-Núñez, M. A. Jones, B. R. Moser, E. J. Cox, M. Lindquist, L. A. Galindo-Leva, N. M. Riaño-Herrera, N. Rodríguez-Valencia, F. Gast, D. L. Cedeño, K. Tasaki, R. C. Brown, A. Darzins and L. Brunner, Appl. Microbiol. Biotechnol., 988413 (2014).

A. Riaz, G. Zahedi, and J. J. Klemeš, J. Clean. Prod., 5719 (2013).

C. E. Aristizábal-Alzate, DYNA, 83191 (2016).

C. E. Aristizábal, A. F. Vargas, and P. N. Alvarado, I Simposio de Química Verde, p. MARA02. 2017.

A. P. Butiuk, M. A. Martos, O. Adachi, and R. A. Hours, "J. Appl. Res. Med. Aromat. Plants, 327 (2015).

K. M. Vanden Bussche and G. F. Froment, J. Catal., 1611 (1996).

K. M. Holmgren, T. Berntsson, E. Andersson, and T. Rydberg, Energy, 45817 (2012).

G. Bozzano and F. Manenti, Prog. Energy Combust. Sci., 56 71 (2016)

C. E. Aristizábal, P. N. Alvarado, and A. F. Vargas, in VI Jornada Técnica Internacional de iIngeniería Química y Ingeniería Biológica, 2018.

A. Burniol-figols, K. Cenian, I. V Skiadas, and H. N. Gavala, Biochem. Eng. J., 11654 (2016). 


\title{
Pyrolytic Kinetic Studies, Energetic Potential and Gasification Simulation Process of the Green Microalga Botryococcus Braunii
}

\author{
Andrés A. Arbeláez ${ }^{\star}$, Néstor D. Giraldo*, Juan F. Bayer ${ }^{\star}$ Lucía Atehortúa ${ }^{\star}$
}

Universidad de Antioquia, Medellín, Colombia E-mail:

alonso.arbelaez@udea.edu.co

\section{Introduction}

The development of technologies for the use of renewable sources for fuel production is a key step in the transition from the oil-based model to a more diverse and environmentally responsible one [1]. In this transition, new alternatives have raised, such as the use of biomass as an input to generate solid, liquid and gaseous fuels compatible with current energy technology [2]. Biomass comprehends a broad portfolio of plant-derived materials such as wood, grains, forage, agroindustrial wastes and mass produced by microorganisms. Microalgae biomass is interesting, not only because of its potential in terms of energy but also for the possibility of establishing a biorefinery that produces energy and higher value products, such as proteins and bioactive compounds [3]. One of the most suitable microalgae species to use as raw material for energy purposes is Botryococus braunii, a green microalga known for its ability to produce and accumulate significant amounts of liquid hydrocarbons, suitable to produce biofuels [4].

Thermochemical conversion of microalgae is an attractive way to transform biomass into different forms of useful energy [3]. These processes mainly include direct combustion to generate heat and electricity, pyrolysis and gasification to produce liquid and gaseous fuels suitable for engines and turbines. Pyrolysis plays an important role in thermochemical conversion processes, being the chemical starting point of gasification and combustion processes. It can be divided into two consecutive scenarios that involve thermal decomposition of biomass through the evaporation of the most volatile compounds, and a slow heterogeneous conversion to coal [5]. Biomass gasification is considered the most promising process, with the best cost / benefit ratio for the conversion of biomass into energy [6]. Gasification is a technology that converts solid materials composed mostly of carbon (such as biomass) into syngas through a thermochemical conversion. Syngas is mainly composed of hydrogen, carbon monoxide, carbon dioxide and methane [7]. 


\section{Experimental}

\section{Thermogravimetric Analysis}

The thermal analysis of the biomass sample was carried out using a TGA Q500 V20.13 Build 39. During the pyrolysis process the samples were pre-treated at $110^{\circ} \mathrm{C}$ to remove moisture, then the temperature was brought to $800{ }^{\circ} \mathrm{C}$ at four different constant heating rates $\left(10,20,30\right.$ and $\left.40{ }^{\circ} \mathrm{C} / \mathrm{min}\right)$. A nitrogen flow at $60 \mathrm{ml} / \mathrm{min}$ was supplied to remove the air and prevent sample oxidation. The rate of weight loss $(\mathrm{dX} / \mathrm{dt})$ for the biomass was represented by a derivative thermogravimetric curve (DTG).

\section{Heating value}

The biomass Higher Heating Value (HHV) and Lower Heating Value (LHV) were estimated from $2 \mathrm{~g}$ of dry biomass by a simple jacket pump calorimeter (1341 Parr model 2901EB), according to the manufacturer's specifications.

\section{Simulation Gasification Process}

In the present work a simulation of the gasification process was performed, based on a model established by [8]. This model expresses the reactions of the gasification process in terms of mass and energy balances. This model allows predicting the composition of the "Producer Gas" (PG) or synthesis gas and the reaction temperature of the gasification process. Because of this, it is possible to determine other important parameters such as lower calorific value (LHV) and engine fuel quality (EFQ) from the composition of the gasification products [8-9]. These parameters define the quality of the PG fuel for applications in internal combustion engines. Therefore, the model is useful to simulate the composition of the PG depending on the composition of biomass, the moisture content and the ratio between the amount of stoichiometric air required for a complete combustion and the real amount of air used for combustion during the simulation $\left(F_{r g}\right)[8-9]$.

\section{Results and Discussion}
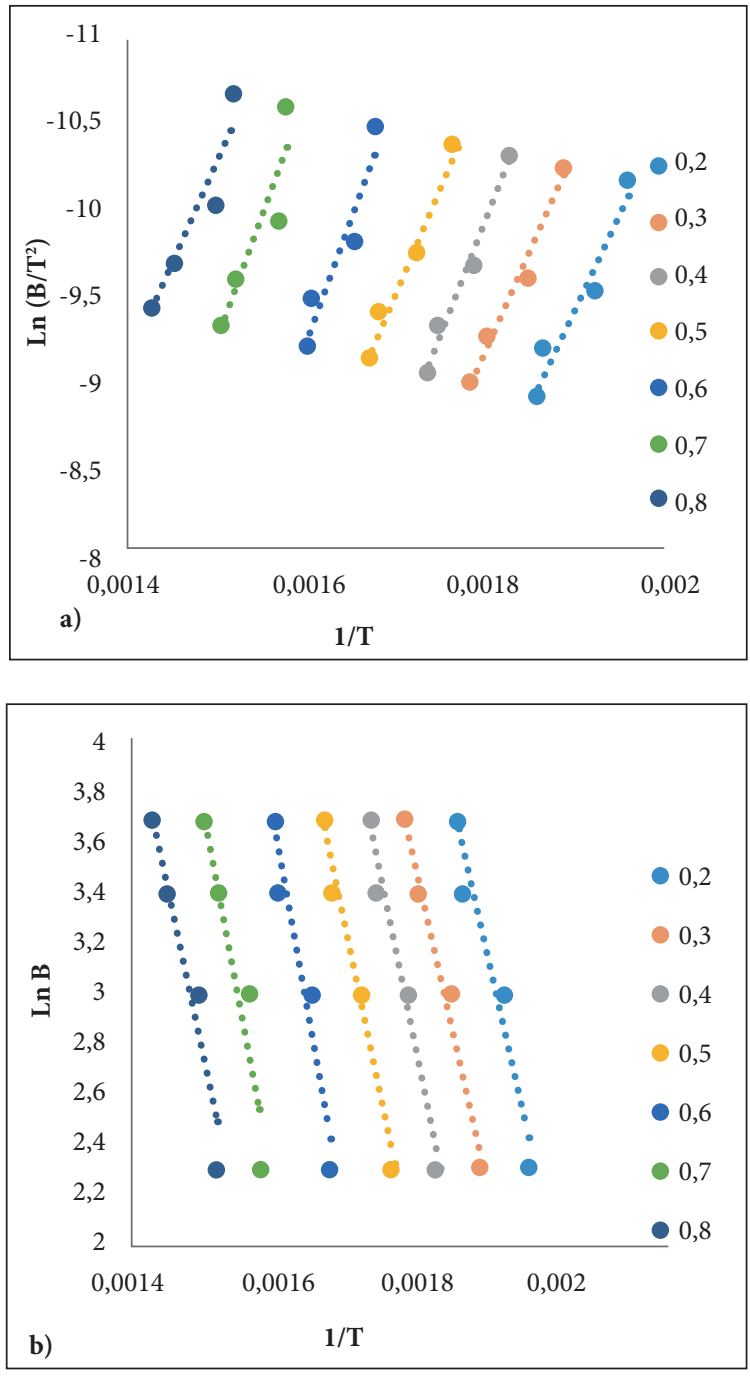

Figure 1. Activation energy plot using different conversion values (a) a. KAs and (b) FWo methods

Figure 1 shows the slope obtained with two methods to determine activation energies for various degrees of microalgal biomass conversion. The energies obtained are comparable between the methods 
used. The energy range goes from 90 to $120 \mathrm{KJ} / \mathrm{mol}$ depending on the degree of conversion required. These activation energies found in the study from $B$. braunii are lower than those reported in other works with microalgae and raw materials used for the production of energy [10-11]. The calorific value (Figure
2) is a crucial indicator that reveals the potential for industrial applications of biomass. B. braunii showed a calorific value of $27.86 \mathrm{MJ} / \mathrm{kg}$ (HHV) and $24.73 \mathrm{MJ} /$ $\mathrm{kg}$ (LHV), which is higher than what several studies for other microalgae strains, woody biomass and colombian coal have reported [12-13].

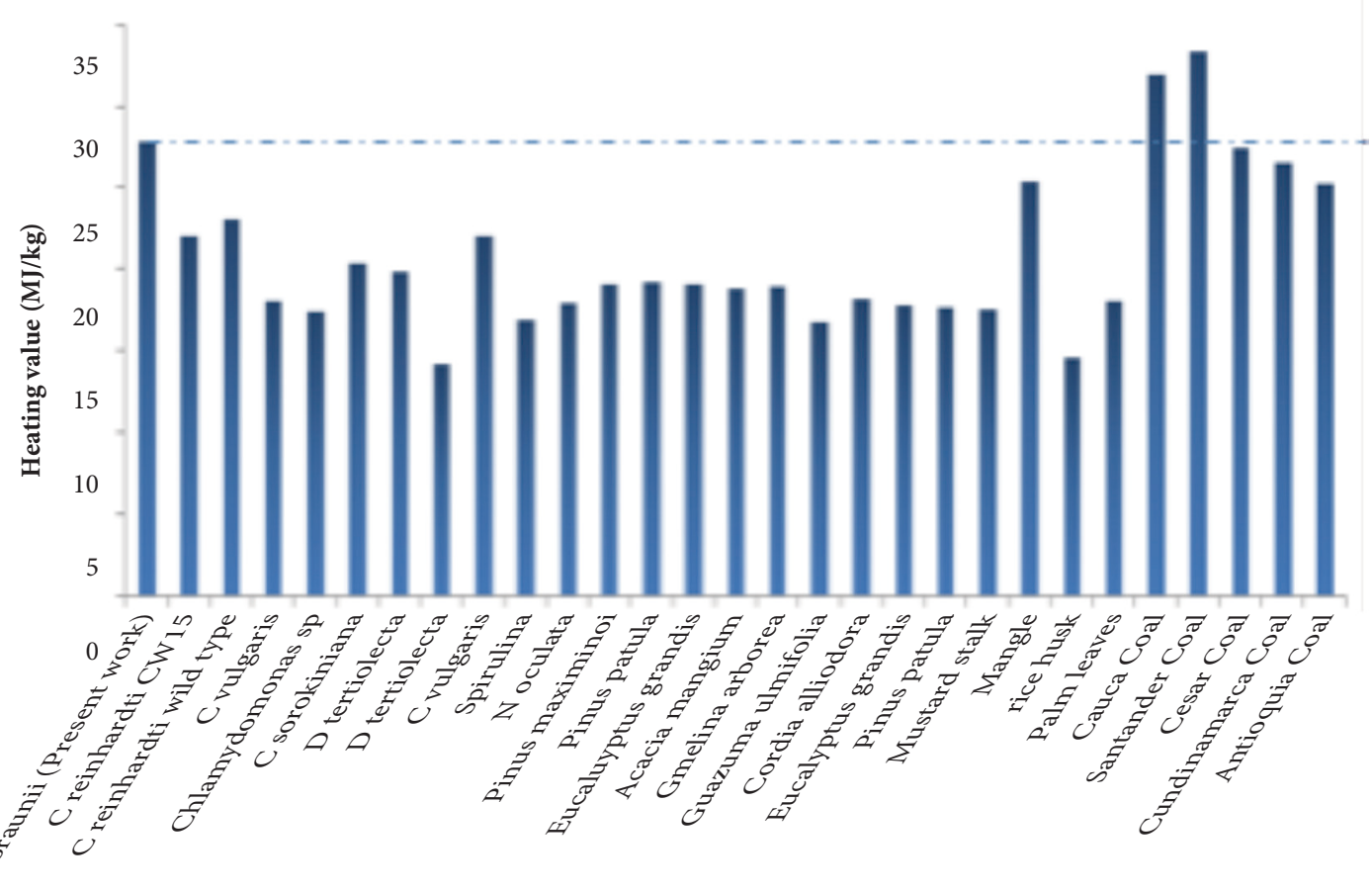

Figure 2. Calorific value of different biomass and fossil sources
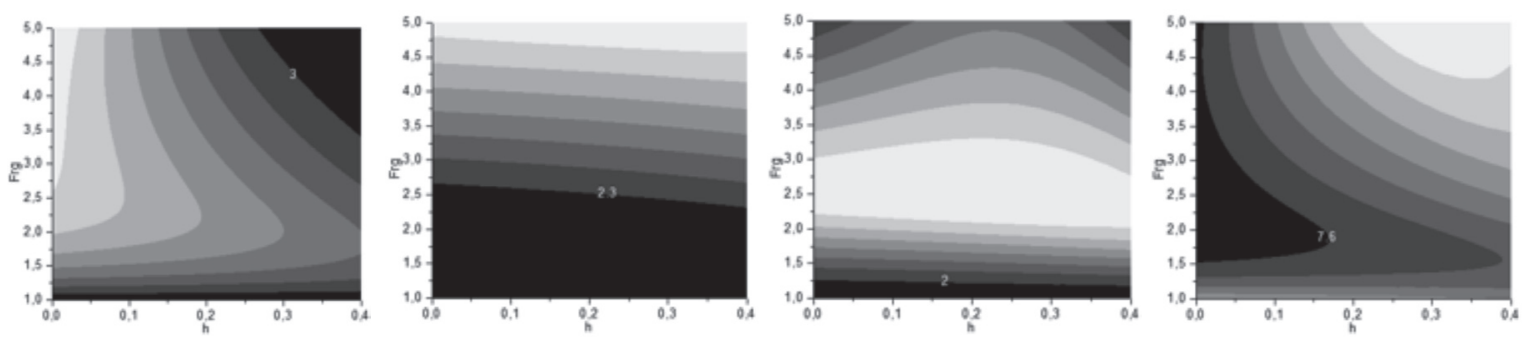

Figure 3. Volumetric distribution simulation of syngas components (\%) as a function of moisture content and $F_{r g}$. Left to Right: (1) CO $3: 3: 21 ;$ (2) $\mathrm{H}_{2} 2: 2.5: 17$; (3) $\mathrm{CH}_{4} 2.3: 2.5: 17.3 ;$ (4) $\mathrm{CO}_{2} 7.6: 1.9: 19$ 
In the gasification process, it was possible to observe that the temperature is mostly affected by the Frg, tending to a temperature increase in ratios near the stoichiometric, and decreasing when increasing the amount of biomass in the reaction. $\mathrm{CH}_{4}$ production is inversely affected by temperature because its content increases significantly as the process temperature decreases [8]. The high production of $\mathrm{H} 2$ is found at temperatures close to $1200^{\circ} \mathrm{C}$, reaching almost $20 \%$ of the composition of the gas produced. Both $\mathrm{CO}$ and $\mathrm{CO}_{2}$ are mainly affected by the humidity of the biomass in an inverse manner. The $\mathrm{CO}$ content is favoured by low percentages of humidity, while $\mathrm{CO}_{2}$ increases when intensifying this parameter [9].

\section{Conclusions}

The calorific power of Botryococcus braunii found in this study (27.86MJ/kg-HHv) suggests suitability as an alternative source of energy, presenting higher values than several species of microalgae, ligneous or lignocellulosic biomass and coal. The activation energy is low compared to different sources of commonly-used solid fuels, such as coal and woody biomass. The simulation showed that with a combination of the correct variables $\left(h, F_{r g}\right)$, it is possible to obtain a syngas composed of high energy content gases. These gases are transformed into liquid fuels as kerosene or gasoline in processes such as hydrothermal liquefaction. The overall process has lower environmental impact when compared to that presented by fossil fuels nowadays.

\section{Acknowledgements}

We thank the Biotechnology group, GIMEL, Colciencias, $\mathrm{ANH}$, for the financing, accompaniment and collaboration in the development of this work.

\section{References}

G. Liu, Y. Liao, Y. Wu, X. Ma, L. Chen, International Journal of Hydrogen Energy, 4222730 (2017).

Y. Uemura, S. Saadon, N. Osman, N. Mansor, K. Tanouoe, Fuel, 144171 (2015).

D. L. Gonzales, M. F. López, J. L. Valverde, S. L. Sánchez, Energy, 7333 (2014).

A. Banerjee, R. Sharma, Y. Chisti, U. Banerjee, Critical Reviews in Biotechnology, 22245 (2002).

C. Blasi, Progress in Energy and Combustion Science, 35121 (2009).

H. Lasa, E. Salaices, J. Mazumder, R. Lucky, Chemical Reviews, 1115404 (2011).

L. Tiong, M. Komiyama, Y. Uemura, T. Thanh, The Journal of Supercritical Fluids, 107408 (2016).

A. Melgar, J. Pérez, H. Laget, A. Horillo, Energy Conversion and Management, 4859 (2007).

J. Pérez, A. Melgar, A. Horillo, International Journal of Sustainable Energy, 361010 (2016).

S. Ceylan, D. Kazan, Bioresource Technology, 1871 (2015).

T. Yuan, A. Tahmasebi, J. Yu, Bioresource Technology, 175 333 (2015).

W. Chen, B. Lin, M. Huang, J. Chang, Bioresource Technology, 184314 (2014).

R. Zapata, J. Bayer, C. Jiménez, Revista Ion, 2743 (2014). 


\title{
Fique as Thermal Insulator. Thermal Characterisation of Fique Fibres
}

\author{
Gabriel F. García Sánchez ${ }^{\star}$, Rolando E. Guzmán*, Adriana M. Restrepo ${ }^{\star \star}$, Emil Hernández $^{\star}$
}

\footnotetext{
Grupo de Investigación en Desarrollo Tecnológico, Mecatrónica y Agroindustria - Gidetechma, Universidad Pontificia Bolivariana - UPB, Bucaramanga, Colombia

** Grupo de Investigación sobre Nuevos Materiales, Universidad Pontificia Bolivariana - UPB, Medellín, Colombia E-mail: gabrielf.garcia@upb.edu.co
}

\section{Introduction}

Nowadays our society faces the great challenge of global warming, which has caused serious problems such as droughts, natural disasters, heat waves and global sea level rise [1]. To face this problem, it is necessary to exploit clean energy sources and reduce society's energy consumption, which directly relates to the building sector for it is one of the sectors with the highest energy consumption worldwide. It is estimated that buildings consume around $40 \%$ of energy, $25 \%$ of water and $40 \%$ of the world's resources; besides accounting for $1 / 3$ of the global greenhouse gas emissions [2-4]. Within this context, thermal insulators are very important since their use is recognized as one of the most efficient ways to reduce energy consumption in buildings [7-10]. However, common thermal insulators are materials made from petrochemical products or from natural sources processed with high-energetic consuming methods. This causes environmental problems, due to the high energy consumption, pollutant emissions and waste generation, mainly in the production stage [10-11], and serious human health problems caused by its harmful components [12-14]. These problems have motivated the use of bio insulation materials made from natural and recycled products. Despite that bio insulators are being studied since 1974, their peak of interest aroused from 2010 onwards because of the increased use of air conditioning systems, greater environmental awareness and changes in the use of biomass [10].

Fique (Furcraea bedinghausii) is a plant of great importance for Colombia, to the point of being the first worldwide producer with a production of about 30,000 tons / year [19]. However, there are few works about its application for thermal insulation. Studies have shown that the thermal conductivity of materials derived from fique can be compared with that of common commercial insulators [19-23]. Nevertheless, other important thermal properties such as specific heat have not been studied; these are crucial for the evaluation of thermal dynamic properties. In order to deepen the knowledge of fique as a thermal insulator, the present work exposes a thermal study of three fique samples, namely, natural fique without treatment, fique washed with a commercial softener and fique after having been soaked for 24 hours in the same softener. The study 
presents the analysis of the sample's morphology, Thermogravimetric analysis (TGA) and Differential Scanning Calorimetry (DSC) profiles.

\section{Experimental}

In order to obtain better knowledge of the constitutive form of fique fibres prior to the tests, some raw fibres were cut crosswise and observed in the Scanning Electron Microscope (SEM) of the Universidad Pontificia Bolivariana. Uncut fibres were also observed with the SEM microscope. Afterwards, to determine the fibre weight changes with temperature and measure its thermal stability, a Thermogravimetric analysis (TGA) was performed using the thermogravimetric test bench of the Universidad Autónoma de Occidente in Cali, Colombia. Finally, the samples were subjected to a Scanning Difference Calorimetry (DSC) test, where the energy required for a temperature change is measured. DSC analyses were carried out in the DSC Q2000 test bench of the thermal analysis laboratory of the Universidad Autónoma de Occidente, in Cali, Colombia.

\section{Results and Discussion}

In the sample images taken using the SEM microscope, it was observed that the natural fibres have a hierarchical structure composed of vascular vessels of elementary fibres (fibrils) and cellulose micro-fibrils packed in a network of hemicellulose and lignin. Micro-fibrils are wound helically along the fibre axis and form hollow cells. Each fibre cell is made up of four main parts, namely the primary wall, the thick secondary wall, the tertiary wall and the lumen. With the cross sections it was possible to observe that both the fibre and lumen diameter varied in size from 10 $\mu \mathrm{m}$ to $20 \mu \mathrm{m}$, with a general geometry that approximated a well-defined circle. The longitudinal images showed that fique fibres have an irregular shape, with thickness variations and superficial damage (breakage), which can be produced in the mechanical defibring process carried out by farmers.

The TGA analysis showed that all samples present two temperatures of appreciable weight loss. Table 1 shows these temperatures and the percentage of weight loss in each process.

Table 1. Main weight losses of the samples in the TGA test

\begin{tabular}{|l|c|c|c|}
\hline \multicolumn{1}{|c|}{ Sample } & $\begin{array}{c}\text { Natural } \\
\text { fique }\end{array}$ & $\begin{array}{c}\text { Fique was- } \\
\text { hed with } \\
\text { softener }\end{array}$ & $\begin{array}{c}\text { Fique } \\
\text { soaked in } \\
\text { softe- } \\
\text { ner-24h }\end{array}$ \\
\hline $\mathrm{T} 1\left(^{\circ} \mathrm{C}\right)$ & 255 & 240 & 195 \\
\hline $\mathrm{T} 2\left({ }^{\circ} \mathrm{C}\right)$ & 365 & 385 & 380 \\
\hline Weight loss 1 (\%) & 7.98 & 9.40 & 9.30 \\
\hline Weight loss 2 (\%) & 21.25 & 16.93 & 22.86 \\
\hline Weight loss 3 (\%) & 50.09 & 56.20 & 47.71 \\
\hline Weight loss 4 (\%) & 2.54 & 1.95 & 3.39 \\
\hline Weight loss 5 (\%) & 81.86 & 84.49 & 83.26 \\
\hline
\end{tabular}

DSC tests revealed that all the samples present a step-type transition caused by the fibre's glass transition, followed by an endothermic transition, which can be attributed to fibre dehydration. Finally, an exothermic transition was observed; it may be attributed to a possible combustion of the material due to the high temperature reached. Temperatures at which these transitions and energy transfer occur vary for each sample. Table 2 presents the comparison of enthalpies involved in the phase transitions.

Table 2. Comparison of enthalpies involved in the phase transitions of the samples

\begin{tabular}{|l|c|c|c|c|c|c|c|c|}
\hline \multirow{2}{*}{$\begin{array}{c}\text { Fique } \\
\text { sample }\end{array}$} & \multicolumn{2}{|c|}{ Vitreous transition } & \multicolumn{2}{c|}{$\begin{array}{c}\text { Anomaly 1 } \\
(\text { Endothermic) }\end{array}$} & \multicolumn{2}{c|}{ Anomaly 2 (Endothermic) } & \multicolumn{2}{c|}{ Anomaly 3 (Exothermic) } \\
\cline { 2 - 10 } & $\begin{array}{c}\text { Temperature } \\
\left({ }^{\circ} \mathrm{C}\right)\end{array}$ & $\begin{array}{c}\text { Enthalpy } \\
(\mathrm{J} / \mathrm{g})\end{array}$ & $\begin{array}{c}\text { Temperature } \\
\left({ }^{\circ} \mathrm{C}\right)\end{array}$ & $\begin{array}{c}\text { Enthalpy } \\
(\mathrm{J} / \mathrm{g})\end{array}$ & $\begin{array}{c}\text { Temperature } \\
\left({ }^{\circ} \mathrm{C}\right)\end{array}$ & $\begin{array}{c}\text { Enthalpy } \\
(\mathrm{J} / \mathrm{g})\end{array}$ & $\begin{array}{c}\text { Temperature } \\
\left({ }^{\circ} \mathrm{C}\right)\end{array}$ & $\begin{array}{c}\text { Enthalpy } \\
(\mathrm{J} / \mathrm{g})\end{array}$ \\
\hline Natural & -7.020 & 2.00 & $2,00-130$ & 247.3 & - & - & 301.28 & 15.93 \\
\hline Softener & -14.53 & 1.50 & $2,00-130$ & 184.2 & 134.63 & 1.173 & 300.05 & 15.92 \\
\hline $24 \mathrm{~h}$ Softener & -11.22 & 0.90 & $2,00-130$ & 176.6 & 148.81 & 5.171 & 293.75 & 8.99 \\
\hline
\end{tabular}




\section{Conclusions}

When visualizing the fibre cross-sections, several hollow cavities in its structure were identified. The capacity of fibre to store air in the found cavities can account of the material's low density and thermal conductivity determined in previous studies. The TGA analysis identified the material's degradation temperature at $280^{\circ} \mathrm{C}$ for natural fique samples, and $190^{\circ} \mathrm{C}$ for softener washed samples. All the aforementioned reasons allow to conclude that fique can be used for thermal insulation in homes without suffering thermal degradation problems, as buildings are subjected to temperature below these values. It was also observed that the material looses resistance to degradation when washed with softener, mainly because lignin is removed from the fibre's surface in the process.

The DSC tests showed that the energetic requirement for a temperature change decreases when the fibres are previously washed, which can negatively affect its performance as a thermal insulator. This may also be caused by the fibre's degradation upon washing.

\section{References}

Greenpeace Colombia. “4 Efectos del calentamiento global en el clima”. Available: http://www.greenpeace.org/colombia/ es/Blog/4-efectos-del-calentamiento-global-en-el-clim/ blog/60625/., Nov, 02, 2017 [Accessed: 26-Jun-2018].

United Nations Environment Programme. "United Nations Environment Programme (UNEP) - Sustainable Building and Climate Initiative." Available: http://www.unep.org/sbci/ AboutSBCI/Background.asp. [Accessed: 19-Oct-2016].

U.S. Department of Energy. "Buildings Energy Data Book.” [Online]. Available: http://buildingsdatabook.eren.doe. gov/ChapterIntro1.aspx. [Accessed: 19-Oct-2016].
European Commission. "Buildings" Energy. Available: http://ec.europa.eu/energy/en/topics/energy-efficiency/buildings. [Accessed: 19-Oct-2016].

S. Tangjuank, International Journal of Physical Sciences, 6 4528 (2011).

S. Schiavoni, F. D'Alessandro, F. Bianchi, and F. Asdrubali, Renewable and Sustainable Energy Reviews, 62988 (2016).

A. M. Papadopoulos, Energy and Buildings, 3777 (2005).

L. Liu, H. Li, A. Lazzaretto, G. Manente, C. Tong, Q. Liu, N. Li, Renewable and Sustainable Energy Reviews, 69 912 (2017).

F. Asdrubali, F. D’Alessandro, and S. Schiavoni, Sustainable Materials and Technologies, 41 (2015).

H. Binici, O. Aksogan, and C. Demirhan, Sustainable Cities and Society, 2017 (2016).

N. Mati-Baouche, H. De Baynast, A. Lebert, S. Sun, C. J. Sacristan López-Mingo, P. Leclaire, P. Michaud, Industrial Crops and Products, 58244 (2014).

M. Mounika, K. Ramaniah, A. R. Ratna Prasad, K. M. Rao, and K. Reddy, Journal of Materials and Environmental Science, 31109 (2012).

M. A. Navacerrada, C. Díaz, and P. Fernández, BioResources, 93480 (2014).

D. M. Muñoz and G. C. Cifuentes, Facultad de Ciencias Agropecuarias, 59 (2007).

M. A. Navacerrada, C. Díaz, A. Pedrero, M. Isaza, P. Fernández, C. Álvarez-Lopez and A. Restrepo-Osorio, "Caracterización acústica y térmica de no tejidos basados en fibras naturales" in EuroRegio2016.

M. A. Navacerrada, C. Díaz, A. Pedrero, P. Fernández-Morales, G. Navarro, and O. Cardona, "Caracterización acústica de muestras de fique tejido y no tejido," presented at the $44^{\circ}$ Congreso español de acústica encuentro ibérico de acústica, España, 2013.

L. V. Monsalve, I. H. Bolañoz, P. F. López, and E. F. Toro, Revista Colombiana de Materiales, 0332 (2014). 


\title{
The Potential of Methane Production using Aged Landfill Waste in Developing Countries: A Case Study in Colombia
}

\author{
Diana M. Caicedo-Concha*; John J. Sandoval-Cobo ${ }^{\star * *}$, Ramón F. Colmenares-Quintero ${ }^{\star *}$, Luis \\ T. Marmolejo-Rebellón ${ }^{\star * *}$, Patricia Lozada ${ }^{\star * *}$, Sonia Heaven ${ }^{\star * * *}$
}

* Universidad Cooperativa de Colombia, Faculty of Engineering, Cali, Colombia

** Universidad Cooperativa de Colombia, Faculty of Engineering, Medellín, Colombia

*** ECCA Group, Faculty of Engineering, Universidad del Valle, Cali, Colombia

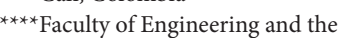
Environment, University of Southampton, Southampton, UK E-mail:

diana.caicedoc@campusucc.edu.co

\section{Introduction}

In the current context of climate change and global energy demand, the use of energy from waste has become a strategy for the reduction of greenhouse gas (GHG) emissions and the replacement of fossil fuels by other non-conventional energy sources through the use of biogas produced in landfills. Although there have been some improvements in solid waste management practices in Colombia, current levels of recycling and material recovery are still weak, only about $10 \%$ of the waste produced is recovered. It is expected that, as for most developing countries, final disposal in landfills will continue to be the main form of Municipal Solid Waste (MSW) management in the coming decades [1].

Waste degradation optimization and stabilization processes have been identified as essential key aspects for environmental performance and economic sustainability of waste management systems in developing countries [2]. However, assessing the feasibility of biogas production in landfills requires a reasonable level of accuracy for the generation of methane, a sufficient understanding of the underlying generation processes and their relation with the physicochemical properties of waste and landfill disposal conditions. Source segregation of MSW is either poor or non-existing in Colombia, as in most developing countries, which makes difficult to predict landfill gas generation, even with the aid of current landfill emissions models.

In developing countries, few studies have been conducted to characterize the biogas production potential of aged landfilled MSw; certainly fewer have evaluated biogas and $\mathrm{CH}_{4}$ generation using aged excavated samples. In this study we show the results of Biochemical Methane Potential (BMP) tests with 4 to 5 years old samples of municipal solid waste (MSW) excavated from a landfill site located in Colombia. Collected samples were characterized, as well as the easy and medium biodegradable fractions used in the experiments. The results show a total production of $0.143 \pm 0.1$ litres of $\mathrm{CH}_{4}$ per gVS added which is comparable with similar studies using excavated landfilled waste of similar characteristics. These results show that the potential of methane production from landfilled waste in developing countries should be considered as a mean to enhance the environmental performance of landfill sites, due to their potential to reduce 
uncontrolled $\mathrm{CH}_{4}$ emissions and promote the use of non-conventional energy sources.

\section{Experimental}

The residue was obtained from a regional sanitary landfill serving 21 small and medium-sized municipalities located at the northern part of the Valle del Cauca region in Colombia. The area has an average temperature of $23{ }^{\circ} \mathrm{C}$ and a bimodal precipitation regime with rainfall peak levels during March-May and September-November periods. In July-August annual precipitation can be below $1,500 \mathrm{~mm}$. Approximately 760 tonnes of MSW are disposed in the landfill every day, mostly composed by food and yard waste (53.5\%), plastics (15.2\%), paper and cardboard (6.6\%), ceramics (5.4\%), toilet paper (4.6\%), textiles (3.7\%) and others (11\%) in a wet-basis.

An aged waste sample of $200 \mathrm{~kg}$ was collected from 3-4 m depth in a cell known to have refuse 4-5 years old. Composition analysis was carried out on site in a wet state, in order to closely represent the conditions of the waste in the landfill, modified methodologies for unprocessed Msw [3] followed. Reconstituted samples with the same proportion of the easily and less easily excavated biodegradable waste fractions were used in the BмР experiments.

Dried, shredded Msw samples (250 g) were incubated at $35 \pm 1{ }^{\circ} \mathrm{C}$ using one litre batch reactors. Anaerobic biosolids taken from a mesophilic digester treating municipal wastewater were used as inoculum. The ratio of inoculum-to-substrate used was 0.81 , based on the materials' vs. content . Tests were run by triplicate during 30 days against blanks with no substrate added. Before incubation, reactors were flushed with nitrogen to remove oxygen. Biogas was collected in $1.9 \mathrm{~L}$ cylinders filled with an acidified sodium chloride solution $(\mathrm{pH}<2)$ and samples were taken periodically to determine $\mathrm{CH}_{4}$ composition by gas chromatography. The measured volume of biogas and $\mathrm{CH}_{4}$ produced was corrected for the gas produced from the blank reactors containing only anaerobic biosolids. Cumulated volumes of biogas and $\mathrm{CH}_{4}$ produced are given for a dry gas at standard temperature $\left(0^{\circ} \mathrm{C}\right)$ and pressure $(1 \mathrm{~atm}$.) conditions.

\section{Results and Discussion}

After sorting, composition analysis in a dry basis for the easily and less easily biodegradable fractions in the excavated waste showed a high content of non-easily identifiable materials (65\%). This is a well degraded material characterised by soil-like and putrescible fractions difficult to associate to a specific waste category. Plastics (16\%), yard waste $(8.2 \%)$, paper and cardboard (7.2\%), as well as textiles (3.1\%) were also identified, despite the 4 to- 5 years of waste degradation.

The main results obtained are presented in figure 1. Lines identified as Ag 1, Ag 2 and Ag 3 represent the residue tested, whereas the lines identified as In 1 and In 2 represent the blanks with no substrate added. Both the biogas and methane production results were within the range of values reported in BMP tests using landfilled MSw with similar characteristics [4]. Biogas production of 63.8-98.2 L kg-1 of dry matter (DM) and methane yields in the range of 23.3-37.1 $\mathrm{L} \mathrm{CH}_{4} \mathrm{~kg}-1 \mathrm{DM}$ were obtained by the end of the tests. During the first 15 days, Methane content increased from 0 to $42.2 \%$ vol., which indicate a relatively early adaptation of the microbial population to methanogenic growth conditions.

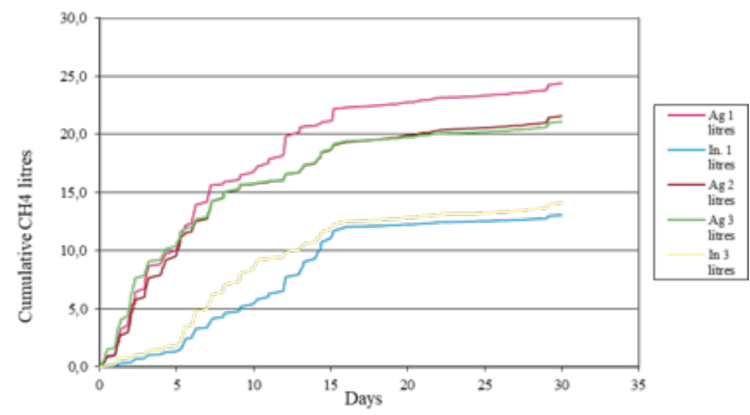

Figure 1. Results of methane produced by the samples of 4 to 5 years old aged waste from a local sanitary landfill

\section{Conclusions}

These findings can give valuable insight about the real potential of biogas and $\mathrm{CH}_{4}$ generation from the un-segregated MSW produced and disposed at 
landfills in developing countries. Also, they can potentially contribute to a better assessment of the recovery potential, treatment and utilization schemes for LFG in developing countries like Colombia.

\section{Acknowledgements}

The Newton Caldas Research Links BC 028-EDu2016, the Industry Academia Partnership call financed by the Royal Academy of Engineering Project Reference \# IAPP1\100166 and the Universidad Cooperativa de Colombia supported the development of this research. Authors also acknowledge the contribution of COST Action FP1306 via promoting networking and collaboration and the support via STSM's.

\section{References}

D. Hoornweg and P. Bhada-Tata, . (2012) What a waste: a global review of solid waste management. [online] World Bank, 2012, Washington, DC. Available: https:// siteresources.worldbank.org/INTURBANDEVELOPMENT/Resources/336387-1334852610766/What_a_ Waste2012_Final.pdf

D. C. Wilson, L. Rodic, P. Modak, R. Soos, A. Carpintero, C. Velis, M. Iyer, O. Simonett. (2015) "The Global Waste Management Outlook (GWMO)”. [Online] UNEP, \& IswA. Available: www.unep.org/ietc

ASTM D5231-92, "Standard Test Method for Determination of the Composition of Unprocessed Municipal Solid Waste” AstM D5231-92, 2016. Available: https://www. astm.org/Standards/D5231.htm

L. Ivanova, "Quantification of factors affecting rate and magnitude of secondary settlement of landfills." Doctoral dissertation, University of Southampton, UK, 2007. 


\title{
Public Policies on Renewable Energies at an International Level: A Study of Systematic Mapping
}

\author{
Jimena Cardona-Cuervo*, Ramón F. Colmenares-Quintero*, Gina Maestre-Góngora*
}

Universidad Cooperativa de Colombia, Colombia

E-mail:

jimena.cardona@campusuc.edu.co

\section{Introduction}

Vulnerable communities located principally in peripheral zones, increasingly demand the provision and access to energy with improved infrastructure, which imply higher costs because simultaneously, they demand the environment's protection. This translates in concrete requests for clean energies and a challenge for governments in a technical, economic and social aspect. Therefore, it is necessary to identify the current state of the construction of public policies in the field of renewable energy sources. This study evaluates 8,903 related scientific articles through a systematic mapping based on the analysis of their title, keywords and abstract.

\section{Methodology}

Systematic mapping is used as a methodology to eliminate or greatly reduce biasing that appears when performing an individual article-reviewing process; hence more reliable results are obtained [1]. This methodology does not seek to deepen the field. On the contrary, it collects data from publications about the topic to show essential elements of the research, such as the journals where the article was published, the most specialized authors, among other elements. The compendium of the gathered information allows the conformation of a global map of the research's state of the art about public policies development in the field of renewable energy. According to [2], mapping often focuses on published documents but can also be used with other media such as books, newspaper and grant proposals. This work, however, excludes the aforementioned media to centre the attention on articles published in Scopus and Science Direct during the last ten years. The methodology consists of the following:

\section{Constructing a research inquiry}

Research questions are intended to find works that can relate to the object of study. Three general questions and three statistics were formulated. The purpose of the first ones was to understand how public policies in the field of renewable energy help improve the quality of life on disconnected communities. The second ones 
seek to find statistical information to identify publication patterns on the topics under study [3]. Then, keywords were chosen in order to guide the research.

Table 1. Keywords

\begin{tabular}{|l|l|}
\hline Public Policies & $\begin{array}{l}\text { - Public policies } \\
\text { - Public policy }\end{array}$ \\
\hline $\begin{array}{l}\text { Unconventional } \\
\text { sources of } \\
\text { renewable energy }\end{array}$ & $\begin{array}{l}\text { - Unconventional sources of renewable } \\
\text { energy }\end{array}$ \\
\hline $\begin{array}{l}\text { Sectors / Nenewable energy } \\
\text { interconnected } \\
\text { zones }\end{array}$ & $\begin{array}{l}\text { - Suinable energy } \\
\text { - Non-interconnected zones }\end{array}$ \\
\hline
\end{tabular}

\section{Designing the search process}

Before starting the search process, it is necessary to indicate that the study will go from the general to the particular. This narrows the niche of results to those that are more specific and relevant for the subject of study. As [4] explains, the deduction as method of investigation allows to extract information from general observations.

A search window from 2008 to 2018 was opened for every keyword. The results were stored in an Excel file and submitted to two different checks. First, the title, keywords and abstract of each work, applying the exclusion criteria explained further on (which only selects studies pertaining public policies in the field of non-conventional sources of renewable energy in non-interconnected areas). Second, the data is copied in a matrix that condenses the basic information and allows access to each of the selected research. For statistical purposes the total number of results for each keyword is indicated. Nevertheless, only those relevant to the topic studied were considered in the matrix.

The first search in Scopus yielded 217 results, 3 of which were selected. The search was also refined with some of the proposed keywords enclosed in quotation marks: "public politics" "non-conventional sources of renewable energy" and "not interconnected sectors". The terms were separated by "or". The same search in Science Direct yielded 615 results, 10 of them were selected.

The second search in Scopus yielded 151 results, 24 of them were successful. The search was refined with the keywords enclosed in quotation marks in order to refine the tracking: "public politics" "energy", both terms separated by "and". The mapping addresses the query in the article's title, abstract and keywords. The same search in Science Direct yielded 5,457 results, 5 were selected.

The third search in Scopus yielded 11 results of which only one was selected. The search was refined using the following keywords enclosed in quotation: "Public Politics", "renewable energy" and "non-interconnected zones", the terms were separated by "and". The query addressed the title of the article. The same search in Science Direct yielded 414 results, 7 of them were selected.

The fourth search in Scopus yielded 4 results, none was successful. The search was refined with the keywords enclosed in quotation marks: "Public Politics" and "sustainable energy", both terms separated by "and". The query centred on the article's title. The same search on Science Direct yielded 1,952 results, 2 were successful.

The fifth search carried out in Scopus yielded 57 results, 11 were selected. The search was refined with the keywords: "Public Politics" "energy" "energy of grid communities" "unconventional sources of renewable energy" "renewable energy" "sustainable energy". The first two terms were separated by "and" the rest by "or". Addressing the query of the first two strings in the title of the article and the others strings in the keywords and abstract. The same search on Science Direct yielded 25 results, 1 was successful. The rest of searches using different keyword combinations and text strings are not documented in this work because they yielded results already obtained in initial searches which would have generated double data.

\section{Defining the criteria to filter the results}

After generating the files with the results of the previous step, the exclusion criteria was set to filter out the important and precisely related work to study.

Table 2. Exclusion criteria

\begin{tabular}{|l|l|}
\hline \multirow{2}{*}{} & The article is not written in English. \\
\cline { 2 - 3 } & The article was published before 2008. \\
\cline { 2 - 3 } & The article is not a complete study. \\
\cline { 2 - 3 } & The article refers to conventional energy. \\
\cline { 2 - 2 } & The article does not deal with Public Policies. \\
\cline { 2 - 2 } & $\begin{array}{l}\text { The article comprises another version of one previously } \\
\text { found and included in the matrix of successful results. }\end{array}$ \\
\end{tabular}


The exposed criterion aimed to eliminate noise in each queries [5] generated by the articles tangentially related to the object of study. The investigation centred on the title to ensure content accuracy. Once the exclusion criterion was applied, the resulting articles decreased, but were also more precise and relevant. All were inserted in an Excel file after exporting essential data to then proceed to the abstracts' analysis.

\section{Results and Discussion}

Research results are generally presented in the form of articles, books and conferences. Searching with the above keywords and limiting the title, abstract and keywords lead to the following concrete results.

Table 1

\begin{tabular}{|c|c|c|c|}
\hline Year & Authors & Title & Journal \\
\hline 2018 & $\begin{array}{l}\text { Daniella } \\
\text { Rodríguez- } \\
\text { Urrego, Leonardo } \\
\text { Rodríguez- } \\
\text { Urrego }\end{array}$ & $\begin{array}{l}\text { Photovoltaic } \\
\text { energy in } \\
\text { Colombia: } \\
\text { Current status, } \\
\text { inventory, } \\
\text { policies and } \\
\text { future prospects }\end{array}$ & $\begin{array}{l}\text { Renewable and } \\
\text { Sustainable } \\
\text { Energy Reviews } \\
{[6]}\end{array}$ \\
\hline
\end{tabular}

This leads to the conclusion that there are few publications in Scopus and Science Direct, which specifically address "Public Policies" in the field of non-conventional renewable energy and non-interconnected areas. However, we found numerous articles in which the topic of interest, delimited by the keywords, are dealt within insolation.

Energy provision services in non-interconnected areas yielded fewer publications in referenced databases. The found publications dealt with public policy issues in the field of renewable energy of forestry, marine and biomass resources.

The most frequent research methods on the subject are qualitative, quantitative and mixed. Among them, there are macroeconomic studies, bibliographic reviews, application of measuring instruments such as surveys and interviews. The inclusion of statistical reports predominates.

The resulting matrix was composed by 64 articles dealing with public policies on non-conventional renewable energy sources. Preliminarily, it seems that the main area of study centres in the energy subject, then followed by environmental science and social science $(28 \%, 27 \%$, and $25 \%$ respectively).

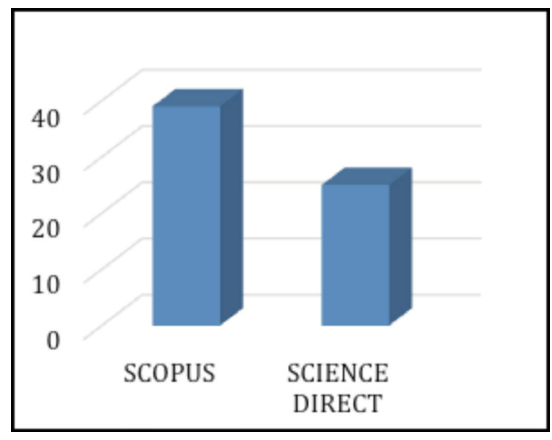

Figure 1. Databases where research has been published

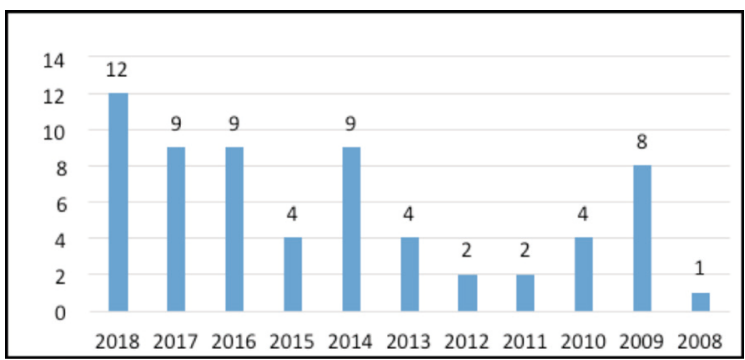

Figure 2. Frequency of publications

\section{References}

J. Bailey, D. Budgen, M. Turner, B. Kitchenham, P. Brereton and S. Linkman, "Evidence relating to object-oriented software design: A survey" in Proc. of the 1st Int. Symp. On Empirical Software Engineering and Measurement, 2007, pp. 482-484.

D. Cooper. J. Med. Library Assoc., 10476 (2016).

L. P. S. Dias, J. L. V. Barbosa and H. D. Vianna. Telematics and Informatics, 35213 (2018).

R. Hernández, C. Fernandez and P. Baptista. Metodología de la Investigación. Mexico: Edamsa Impresiones, 2008.

D. Rodríguez-Urrego and L. Rodríguez-Urrego. Renewable and Sustainable Energy Reviews, 92160 (2018).

B. A. Kitchenham, D. Budgen and P. Brereton. Evidence-Based Software Engineering and Systematic Reviews, Boca Raton, FL: Chapman and Hall/CRC, 2015. 


\title{
Identification of Methodologies in the Teaching- Learning of Renewable Energies
}

\author{
A. Orozco ${ }^{\star}$, K. Benítez ${ }^{\star}$, J. Montes $^{\star}$, Diana M. Caicedo-Concha ${ }^{\star}$, Dario Quiroga-Parra ${ }^{\star}$, \\ Ramón F. Colmenares-Quintero*
}

Universidad Cooperativa de Colombia, Colombia

E-mail:

alexander.orozcob@campusucc.edu.co

\section{Introduction}

Rapid depletion of fossil fuel reserves, population growth and increase of environmental pollution have forced a shift in the search for alternatives to produce and use energy. Also, a need to create citizen awareness about the consequences of energy use and abuse in the surrounding environment has emerged. About 1,000 million people worldwide do not have access to energy, hundreds of millions obtain the resource in an insufficient and inconstant manner and around 300 million use energy sources such as firewood and biomass.

The Sustainable Development Goals (SDGs) constitute a universal call for the adoption of measures to achieve 17 objectives, among which the 7 th one seeks to establish the access to affordable, non-polluting energy. In Colombia, Law 1715 of 2014 regulates the integration of non-conventional renewable energies (RE) to the national energy system; the 0570 Decree of March $23^{\text {rd }} 2018$ establishes the guidelines for contracting RE generation projects. In the UPME (Mining-Energy Planning Unit) there are currently 299 projects registered, that will participate in the auction promoted through the 0570 Decree, $85 \%$ of which correspond to photovoltaic energy, $25 \%$ correspond to small hydroelectric plants, biomass, solar-thermal initiatives, wind, geothermal and hybrid energy sources. The former demonstrates the recent progress made by the country in RE regulation. However, the development of such task in Colombia just begun and requires contributions from the business sector, academia and citizenship. The Universidad Cooperativa de Colombia has undertaken different projects in the field of renewable energies to take advantage of RE potential in Colombia and to work towards the transfer of knowledge to the energy industry. One of those projects, "Identification of Knowledge Gaps in the Academy and Capacity Building for Aquatic Renewable Energy in Colombia" has the objective to "Study the methodologies and strategies used in the teaching-learning process of renewable energies". The findings presented in this abstract show some of the results of the on-going research with a central topic regarding the identification of cases in which energy teaching-learning processes have been carried out. 


\section{Experimental}

Using the keywords "renewable energy" and "teaching" or "pedagogy*", a research was performed using the Scopus database. The search was performed on July 19 $9^{\text {th }}, 2018$ and considered records since 1983, which had 461 entries as a result. Based on this search, it was possible to identify the main authors, countries and institutions that have carried out teaching and learning processes about renewable energies.

\section{Results and Discussion}

Figures 1, 2 and 3 present some of the results. Figure 1 exposes the authors and number of publications, Pecen, Belu and Pelkonen with 8, 7 and 5 publications. Ahponen, Castro, Munukutla, Pastor, Ros and Tobarra with 4 publications. Figure 2 shows the relation between countries and number of publications that demonstrate that 177 publications have been produced in the United States, followed by Germany (29), Spain (24), United Kingdom (17), Australia (17), Turkey (17), China (15), India (12) and undefined country of origin (30).

Figure 3 shows information about the institutions publishing in the area of pedagogy and renewable energies. Drexel University, University of Northern Iowa and Arizona State University, all located in the United States, made 8, 8 and 6 publications each. The National University of Distance Education located in Spain had 5 publications. One aspect that is common to several articles reviewed is the incorporation of practical tools in the teaching-learning processes in renewable energies; which include the use of intelligent micro-networks that manage the demand for electricity [1-2] and photovoltaic systems [3] with orientators for solar panels [4].

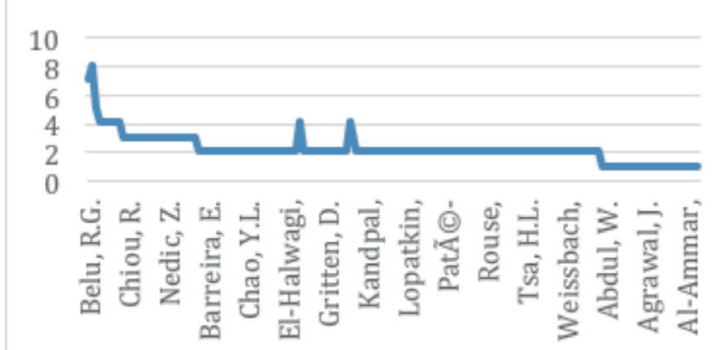

Figure 1. Authors and publications using the keywords "renewable energy" and "teaching" or "pedagogy" from 1983 to date

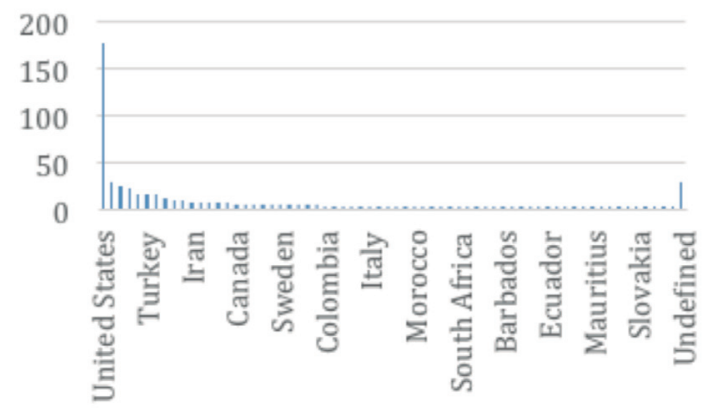

Figure 2. Publications by country of origin using the keywords "renewable energy" and "teaching" or "pedagogy" from 1983 to

today

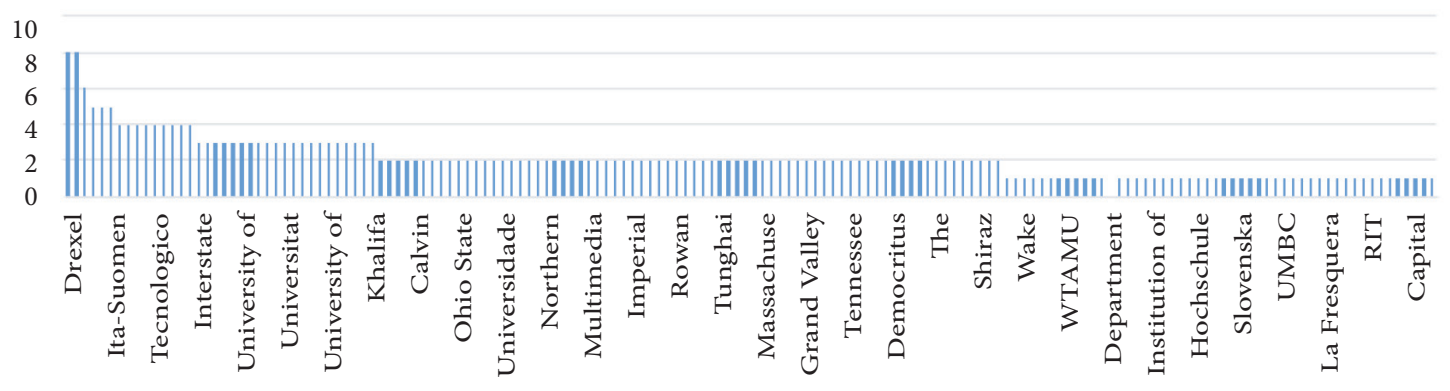

Figure 3. Publications by country of origin using the keywords "renewable energy " and "teaching" or "pedagogy" from 1983 to date 
Academy has the need to train future professionals in renewable energies based on educational models that incorporate components of being, knowing and doing. For this, the practical component plays a very important role. The transfer to the industry was identified through the prototype scaling $[1,3-5]$ and the development of projects that involve the production and installation of renewable energy systems as mechanisms for such transfer [6]. The main obstacle identified has to do with the cost of acquisition and installation of the aforementioned tools. This is the case reported by W. Liu et al. (2018), in which the difficulties encountered in acquiring an energy converter are described [1]. According to Kim and Maitra (2017), the development of projects that involve the production and installation of renewable energy systems, having pilot systems in laboratories at universities and ensuring access to these environments by the university, have an effect on the motivation and interest of students, through practices, they have the opportunity to consolidate the acquired knowledge in a theoretical way [6].

\section{Conclusions}

The use of simulators, software, distant learning and remote laboratory testing has a key role to play in teaching-learning process of renewable energies. The responsibility of the academia in such process is substantial if we, as a country, want to enter a sustainable growth age.

\section{Acknowledgements}

Support for carrying out this research was given by the Industry Academia Partnership call financed by the Royal Academy of Engineering Project Reference \# IAPP1\100166 and the Universidad Cooperativa de Colombia. Also, acknowledgments are given to the contribution of cosT Action FP1306 due to its promoting networking and collaboration and the support via STSMs.

\section{References}

W. Liu, J. Kim, C. Wang, W. Im, L. Liu, and H. Xu, Trans. Ind. Informatics, Article in press (2018).

J. L. Espinoza, L. G. González, and R. Sempertegui. "Micro grid laboratory as a tool for research on non-conventional energy sources in Ecuador" in IEEE International Autumn Meeting on Power, Electronics and Computing, 2017, pp. 1-7.

D. Frankovic, V. Kirincic, and V. Valentic, Int. J. Electr. Eng. Educ., 54189 (2017).

L. Guo, S. Bhanoori, and A. Otieno, J. Eng. Technol., 3444 (2017)

A. F. Avila, R. W. Kenyon, and A. Mickelson. "Green Energy Distribution in Haiti” in Proceedings: GHTC 2017 - Global Humani tarian Technology Conference, 2017, pp. 1-9.

Y. Kim and S. Maitra. "Design of a Portable Demonstration Unit of Solar Power Systems for Analog Electronics Courses" in Conference Proceedings: ASEE Annual Conference and Exposition, 2017. 


\title{
Review of the Technological Solutions for the Implementation of Clean Energies in Ships and their Prospective Integration to a New Generation of Colombian Vessels
}

\author{
Mónica Ruiz-Pianeta*, Gabriela Salas-Berrocal ${ }^{\star}$, Karen Domínguez-Martínez ${ }^{\star}$
}

Science and Technology

Corporation for the Development of Naval, Maritime and Riverine Industries (Cotecmar), Cartagena, Colombia.

E-mail:

kdominguez@cotecmar.com

\section{Introduction}

Marine vessels are a significant source of air pollution mostly due to their exhaust emissions, which result from the combustion of extremely contaminant fuels such as the Heavy Fuel Oil (HFO), Marine Diesel Oil (MDO), and Marine Gas Oil (MGO). In 2014 the emissions of the maritime shipping sector were estimated to be approximately $2.6 \%$ of the global $\mathrm{CO}_{2}$ and Greenhouse Gas (GHG) emissions [1]. This figure is expected to increase in the future, bearing in mind the potential rise of international shipping by 2050 [2]. For this reason, the International Maritime Organization (IMO), as the main international regulatory body for the shipping industry, has stiffened the requirements for environmental compliance. These include Tier III standards setting the targets for nitrogen oxide (NOx) emissions, the creation of the Emission Control Areas (ECA), the adoption of measures as the Energy Efficiency Design Index (EEDI) and the Ship Energy Efficiency Management Plan (SEEMP).

The evolution in regulations for environmental protection imposes new challenges for ship designers as requirements become increasingly stringent. Moreover, other design drivers as sustainability and the reduction of the life-cycle costs for ship-owners also demand the integration of innovative solutions to achieve enhanced levels of energy efficiency and ship performance. Extensive research has pointed out the use of clean energies and state-of-the-art technologies for power generation as responses to these challenges [3-7]. For instance, in [8] the authors analyse the use of alternative fuels in the marine industry, such as the bio-diesel, LNG, methanol and even hydrogen. Further studies present diverse technological solutions to take advantage of the solar and wind energies in ships [9-13], but also the thermal energy that can be recovered from the exhaust gases of propulsion and electrical power generation machinery [14-15]. Other research focus on optimization techniques to reduce energy consumption on board [16]. However, despite the considerable amount of literature available, the current implementation of non-conventional fuels and renewable energies in vessels is still very limited in the international scenario [2]

When it comes to Latin America, particularly in Colombia, the integration of cutting-edge solutions to reduce pollutant emissions into new ship designs is even scarcer. To some extent, this relates with the fact that, to date, 
the Colombian shipbuilding industry produces small to medium size vessels to supply local demand. These ships, designed for maritime and riverine navigation in either military or civilian applications, are exempt of compliance of the IMO environmental regulations. Therefore, when compared to other regions like Europe, Colombian ship-owners and shipbuilders have not been pressed as much to adopt clean energies as a result of the enforcement of international rules.

Although, Colombia has strong motivations to pursue a "green" approach to the design, construction, and operation of ships: The commitment of the country to the Paris Agreement "COP21" and several governmental initiatives [17-18] set a roadmap for the implementation of renewable energies and energy efficiency measures. Hence, it is necessary to introduce this eco-friendly perspective in the future generation of Colombian vessels, capable of undertaking new roles for the post-conflict, including ecotourism, scientific research, and support of the vulnerable communities, whilst contributing to the preservation of national hydrological wealth and biodiversity.

This paper presents a comprehensive review on the state-of-the-art solutions for the reduction of $\mathrm{CO}_{2}$ emissions in ships, summarised in three main areas: Non-conventional fuels, alternative technologies, and energy optimization. Later, a discussion on the potential use of these solutions in the new Colombian designs is presented, it covers topics like pros and cons, the technological risks associated to the implementation and cultural factors involved in the process.

\section{References}

T. W. P. Smith, J. P. Jalkanen, B. A. Anderson, J. J. Corbett, J. Faber, S. Hanayama, E. O'Keeffe, S. Parker, L. Johansson, L. Aldous, C. Raucci, M. Traut, S. Ettinger, D. Nelissen, D. S. lee, D. S, S. Ng, S, A. Agrawal, J. J. Winebrake, M. Hoen, S. Chesworth, A. Pandey. Third Imo Greenhouse Gas Study 2014, London: International Maritime Organization, 2015.
N. Rehmatulla, J. Calleya, and T. Smith, Ocean Eng., 139184 (2017).

J. Hua, Y.-H. Wu, and P.-F. Jin, Renew. Energy, 331056 (2008)

A. García-Olivares, J. Solé, and O. Osychenko, Energy Convers. Manag., 158266 (2018).

A. A. Allal, K. Mansouri, M. Youssfi, and M. Qbadou, «Toward a review of innovative solutions in the ship design and performance management for energy-saving and environmental protection», in 19th IEEE Mediterranean Electrotechnical Conference (MELECON), 2018, pp. 115-118.

R. Tang, Z. Wu, y X. Li, Energy, 162697 (2018).

E. A. Bouman, E. Lindstad, A. I. Rialland and A. H. Strømman, Transp. Res. Part Transp. Environ., 52408 (2017).

D. Argyros, N. Sabio, C. Raucci and T. Smith, «Global marine fuel trends 2030», London: Lloyd's Register Marine and University College London, 2014.

M. Traut, P. Gilbert, C. Walsh, A. Bows, A. Filippone, P. Stansby and R. Wood, Appl. Energy, 113362 (2014).

R. Duckworth, J. Wind Eng. Ind. Aerodyn., 20297 (1985).

A. De Marco, S. Mancini, C. Pensa, G. Calise, and F. De Luca, International Journal of Rotating Machinery, 201612 (2016).

A. Glykas, G. Papaioannou and S. Perissakis, Ocean Eng., 37592 (2010).

H. Lan, S. Wen, Y.-Y. Hong, D. C. Yu and L. Zhang, Appl. Energy, 15826 (2015).

W.-K. Tien, R.-H. Yeh, y J.-M. Hong, Energy Convers. Manag., 481965 (2007).

D. V. Singh y E. Pedersen, Energy Convers. Manag., 111315 (2016).

S. Sherbaz and W. Duan, J. Mar. Sci. Appl., 11335 (2012).

Unidad de Planeación Minero Energética, Integración de las energías renovables no convencionales en Colombia. Bogotá: Ministerio de Minas y Energía, 2015.

Unidad de Planeación Minero Energética, "Plan de acción indicativo de eficiencia energética 2017 - 2022: Una realidad y oportunidad para Colombia”, Ministerio de Minas y Energía, Bogotá, 2016. 


\title{
Methodology for Characterisation of the Vitoyó Village Community - Indigenous Reservation of Jambaló-Cauca
}

\author{
Juliana Benavides*, Ramón F. Colmenares-Quintero*, Sergio Barbosa*, Gina Maestre-Góngora*
}

Universidad Cooperativa de Colombia, Colombia

E-mail:

juliana.benavides@campusucc.edu. co

\section{Introduction}

Currently, Colombia has 87 indigenous clanships located especially in rural areas and organized in legally constituted indigenous reserves. According to the National DANE Census in 2005, 1,378,884 Colombians (from a total of 42,090,502) belong to diverse indigenous communities and correspond to $3.28 \%$ of the total population. They have presence in 27 departments and 228 municipalities in the form of 710 titled indigenous reserves, which occupy approximately 34 million hectares, i.e. $29 \%$ of the national territory. The native population in the department of Cauca are Coconuco, Embera, Esperara Siapidara, Guambiano, Guanaca, Inga, Totoró, Yanacona and Nasa. (DANE, 2007)

The present study aims to characterize the Nasa indigenous community of the hamlet Vitoyó -Jambaló Reserve- in the Cauca Department. This research arises from the need to comply with the resolution issued by the Inter-American Court of Human Rights, for the repair of the community's physical and psychological damage caused by the armed conflict. The data obtained represents a relevant input for the planning and implementation of different projects for the indigenous community. It offers information about the Nasa's living conditions, their cosmovision and original indigenous people to whom this community belongs. These include aspects related to the care of sacred places, cultural adaptation of physical and psychological health practices, and adaptation of basic sanitation and renewable energy systems.

\section{Experimental}

During the first stage the interest focused on sociodemographic and cultural aspects such as: population in general, population by age groups, number of family groups and members by families; territory, climate, economy — crops and productive activities-; culture, beliefs, points of view and customs, religion; communication and transportation routes; place of living; food, education, basic sanitation, energy.

In order to obtain the information, a format was issued, which could be implemented with each family. It was systematically constructed, subsequently 
systematized and the information layout responded accordingly to the aspects to be analysed. At the same time, a database was created to allow the entry and management of the information. All the work was carried out with the permanent participation of people from the indigenous community, health personnel, data entry systems technician, among others, with the purpose of maintaining an intercultural approach. The instrument was implemented to 138 family groups that corresponded to a total of 666 people of different ages, permanent residents of the Vitoyó village. The interdisciplinary team was made up of a nurse, a psychologist, a doctor and traditional doctors, under the general coordination of the Health Program psychosocial area. The characterization of the Nasa's spiritual perspective was carried out by the accompaniment of ancestral knowers and health promoters from the community.

\section{Results and Discussion}

The results of the population characterization were:

From the 666 people in the community, $60 \%$ are children and adolescents, and $53 \%$ are men. The community is considered to be mostly Catholic and a small group belongs to the evangelical religion. The evangelical group generates more tensions in terms of acceptance of rituals and other aspects of its Origin Law, in comparison to the Catholic with whom the community has already generated syncretism.

In terms of activities, $33 \%$ of the population are engaged in agriculture, carried out in precarious conditions; $29 \%$ are students; $28 \%$ of people of productive age are considered unemployed; $9 \%$ are dedicated to housework and $1 \%$ are midwives. These statistics show a lack of work opportunities in the community, which constitutes an important problem considering that its population greatly consists of children and young people.

About $76 \%$ of the dwellings that they inhabit are built in bahareque with floors of dirt. In the $91 \%$ of the homes visited, the families cook with firewood as a response to the absence of a stable energy supply system. As for water supply, $90 \%$ of homes receive water through hoses, $4 \%$ store water in plastic containers, $3 \%$ store water in tanks, and the remaining $3 \%$ in pots and / or cans. The main source of water is the eyes of water and to a lesser extent, water from rivers, which to date have suffered some contamination due to inadequate garbage disposition. The water springs, lagoons, streams and rivers are places to which the Nasa cosmovision grant great spiritual and material value. The loss of eyes of water and the detriment of its quality in the spaces where they sprout has become a relevant cause of various diseases, and disharmony and imbalance from the indigenous perspective. They also lack a system for wastewater management. Similarly, they need a stable energy system that allows improving conditions for activities such as: agriculture, education, home duties and access to technology. The later will make possible to link young population to new and diverse productive projects. In general, there is a need to seek solutions that will improve the community's life quality while conserving and enhancing their indigenous culture.

\section{Conclusions}

The results of the study contributed to build important knowledge about the real-life conditions and the cosmovision of the indigenous Nasa community in the Vitoyó village. The foundations obtained served to propose a comprehensive care route (health, education, energy, infrastructure, among others) from a psychosocial and intercultural approach, endorsed and accepted by the community at the time of its implementation.

The integral attention proposal consisted in the determination of strategies for the preservation of water sources in the medium and long term, basic sanitation strategies for the management of water for consumption, water for cleaning, irrigation of crops, maintenance of animals, adequate maintenance of slaughterhouses, and articulation of intercultural health care strategies from the western and indigenous point of view. Likewise, the findings in this characterization produced inputs for planning and structuring a route for the supply and generation of renewable energy. For all the strategies and work, it was important to always maintain the coherence with the Nasa's worldview.

The creation of a software to support the information generated in the field research work was fundamental. This software allowed the management of a high volume of information with very specific data about the area and the community. In addition, it facilitated the production of graphs for the analysis and presentation of the results in the International 
Congress of Attention to Victims of the Armed Conflict in Colombia.

Considering that the indigenous Nasa community of the Vitoyó village is located in one of the NonInterconnected Zones in Colombia, as defined by the IPSE (Institute for Planning and Promotion of Energy Solutions for Non-Interconnected Zones), and that it preserves its attributes, it is possible to affirm that this experience and methodology might be used and replicated for the characterization of other population of diverse ethnic groups, also located in non-interconnected zones.

\section{Acknowledgments}

The authors thank the project Identification of Knowledge Gaps in the Academy and Capacity Building for Aquatic Renewable Energy in Colombia lead by the Universidad Cooperativa de Colombia, with resources from the Newton Fund of the United Kingdom, in collaboration with Aquatera Ltd., HeriotWatt University and Cotecmar, Ministry of Social Protection, Association of Indigenous Councils of Northern Cauca, Universidad Cooperativa de Colombia.

\section{References}

M. Hammersley, P. Atkinson. Ethnography: Principles and practice, New York, USA: Editorial Routledge, 2007.

J. Benavides. Health care and illness in indigenous communities in the North of Cauca: practices, meanings and disagreements, Cali: Universidad del Valle, 2012.

DANE (2007). Colombia a multicultural nation: its ethnic diversity. [Online] Available: https://www.dane.gov.co/ files/censo2005/etnia/sys/colombia_nacion.pdf 


\title{
Software Development of Carbon and Water Footprint in Coffee Production
}

\author{
Ferley Medina ${ }^{\star}$, Irlesa I. Sánchez ${ }^{\star}$, Jaime M. Cabrera*, Jhon F. Ortiz ${ }^{\star}$, Andrés F. Ortigoza*
}

Universidad Cooperativa de Colombia, Colombia

E-mail:

medina@campusucc.edu.co

\section{Introduction}

This study addresses the determination of Environmental Footprints as an Indicator in the Decision Making for the Integral Management of Special Coffee Production in the south of the Huila Department. The link in the coffee production chain allows a comprehensive understanding of the current problems of this sector, i.e. the quality of special coffees. The entities have articulated through strategic alliances in order to join forces for the management of knowledge, contributing to the environmental sustainability and quality of life of the coffee sector. The project contemplates a strong component regarding carbon and water footprint [1-7], focused on the transfer of technology and social appropriation of knowledge; coffee farmers in general, will benefit from sustainable development and fair-trade agreements with the producers.

\section{Experimental}

The methodology used was qualitative and quantitative research, in a participatory action research type, based on the recognition of the coffee farmers' experience during production processes involving different variables in the software design in order to develop the necessary calculations following an XP methodology. The main variables in the software design for determining environmental footprints during coffee production are carbon and water. The phases the study goes through for addressing the problem are the following:

\section{Phase 1: Analysis and Design}

A sample of 500 coffee growers was used as reference. Observation protocols, documentary information, and encounters were applied to identify variables involving coffee production. In the design phase, the XP methodology is used as reference. It is the system's development approach that controls time, cost, quality, and scope; activities focus on coding, testing, listening, designing and time delivery. All this will make possible data modelling, database design and distribution diagrams. 
The user stories defined the following: 1) data of the four municipalities of the south of the Huila Department; 2) variables to be used; 3) personnel required with their respective roles; 4) restriction schemes; 5) input and output interfaces; 6) necessary elements catalogue; 7) calculations of the environmental footprints; 8) data model; 9) database design; 10) planning and modelling of processes; 11) managing surveys; 12) catalogue of new elements; 13) entry of variables for the calculation of the footprint; 14) planning and modelling of processes, and management of system users. Additionally, the platform must have the ability to perform environmental footprint calculations with the proposed algorithms, to determine early warnings of: flowering, production, drill warnings, rust, renewal, fertilization and opportune sowing times.

The required roles to carry out the project are: Project Manager, who monitors and executes the project within the established deadlines. Administrator, in charge of managing the parametric part of the application, and security. Analyst, collects the requirements, restrictions of the end user and translates them in a language understandable to the developer and databases administrator. Database administrator, design, implementation, maintenance of the database system, policies, procedures related to the management, security, maintenance and use of the database management system. Developer, responsible for programming the critical and non-critical features of the application. Software tester, responsible for the design, executes and reports the results of the tests on the developed platform. The data model for the carbon and water footprint calculator are: department, user, role, municipality, association, farms, lots, agricultural practices, equipment, labour, variables, type of labour, survey, data surveyed, and the processing of results.

\section{Phase 2: Development}

For the planning and modelling of the processes, Enterprise Architect was implemented. The implementation softwares were: JavaScript Framework for graphical user interfaces, application servers built in NodeJS, and MySQL database engine. The result obtained may be observed in: http://huellas.tovarse.com/page-finca. php. The web application that calculates carbon footprints and water footprint during coffee cultivation was developed by integrating technologies under a free licensed software to achieve efficiency and effectiveness in its performance. For this, five aspects were selected: scalability, flexibility, adaptability, interoperability and modularity. The git version 2.10 [8] was applied for version control system to manage file access and maintain the history of changes. Likewise, for hosting the source code on a remote access server the study used the GitHub platform [9].

\section{Front-End}

In the presentation, HTML 5 was used as structure language. With the Bootstrap framework version 3.3.7 the design and adaptability of the application was obtained [10]. Additionally, AngularJS version 2 was integrated, it is a framework aimed for creating SPAs and aims to achieve fluency in Ux, as well as NodeJS [11]. With the Single-Source-of-Truth model, all visual changes are updated in real time in the model and vice versa. With JsON, data exchange was achieved.

\section{Back-End}

To program the business, Python version 3.0 [12] was implemented. Together with the Django version 1.9 framework, it was possible to simplify programming using the DRY (Don't Repeat Yourself) principle, which consists in keeping the code simple and non-repetitive. Django has an ORM by default and integrates the MVT architecture (Model-Template-View), which is a modification of the MVC pattern [13]. It also has a hierarchical system of templates that favours code reuse and extensibility of applications. Likewise, it offers a separation of responsibilities between the activities carried out by the programmer and designer without colliding.

\section{Database manager}

MySQL 5.7 [14] is used in the data layer, considering its potential for scalability, efficiency, and speed in data processing thanks to the multithreading and multiuser system; It supports the synchronization of data with managers such as SQLite [15-16], allowing the integration of a native mobile application to process data on farms where there is no internet connection. With the integration of the aforementioned tools, the aim was to develop a web application that adapts to mobile devices and offers efficiency in data delivery. Likewise, obtain an organized structure in the source code, allowing agile development and flexibility for future modifications. 
To look for an easy and interactive user navigation in the web platform, the establishing of a good quality graphic interface is of great relevance, keeping in mind factors such as usability, accessibility, navigability and portability. The web design contained the main page and the views where it is listed, modified, added, consulted and surveyed and allows its replication in the other tables that are required in the project. The achievement consisted in the hosting of the web service application with the following features: disk space of $8 \mathrm{~GB}$, monthly transfer of $80 \mathrm{~GB}$, unlimited emails, FTP accounts and databases, security certificate.

\section{Conclusions}

During the software design that aimed to calculate carbon and water footprint in the production of coffee, the XP methodology was applied. It allows obtaining software in a short time and at a low cost. The qualitative and quantitative research process allows identification of variables involved in the production of coffee, which contribute to a good design and development of software with certifiable fingerprint models, according to the GHG protocol and the PAS 2050 standard.

It is necessary to generate awareness of the environmental impact of coffee production and to be able to design software that verifies the source and sectors that generate GHG emissions and contaminated water.

\section{Acknowledgements}

The institutions that were part of the research project were: Gobernación del Huila, Universidad Surcolombiana, Servicio Nacional de Aprendizaje - SEnA, Mild coffee company N.V., Mild coffee company Huila, Universidad Cooperativa de Colombia.

\section{References}

D. Auzias, Colombie 2014-2015 Petit Futé (avec cartes, photos + avis des lecteurs), Paris: Petit Fute, 2013.

ISAGEN, "Inventario de emisiones de gases de efecto invernadero" Jan 02, 2014. [Online]. Available: https://www. isagen.com.co/documentos/2015/inventario-de-emi- siones-de-gases-de-efecto-invernadero.pdf. [Last Access: Jun, 5, 2016].

Instituto Superior del Medio Ambiente, "Qué beneficios tiene el cálculo de la huella de carbono” Jan 02, 2012. [Online]. Available: http://www.ismedioambiente.com/ agenda/\%C2\%BFque-beneficios-tiene-el-calculo-dela-huella-de-carbono. [Last Access: March 05, 2016].

Conservación y carbono, "Huella Hídrica" Jan 03, 2016. [Online]. Available: http://www.conservacionycarbono.com/servicios/huella-hidrica. [Last Access: March 06, 2016].

R. Martinez Castillo, Actualidades Investigativas en Educación, 81 (2008).

E. F. Viglizzo, "Huella de carbono, ambiente y agricultura en el cono sur de Sudamérica” Instituto Interamericano de Cooperación para la agricultura, Argentina, 2010.

Ministerio de agricultura, alimentación y medio ambiente, "Guía para el cálculo de la Huella de Carbono y para la elaboración de una planta de mejora de una organización” Secretaria General Técnica, Madrid, 2016, pp. 1-6.

L. A. Rojas Adames, F. Medina Rojas, I. I. Sánchez Medina y J. M. Cabrera Medina, "Ingeniero de Inclusión Social: Software administrativo para minimercados" in UTP Congress Proceedings: 4to Congreso Internacional AmITIC, 2017, pp. 51-54, 2017.

A. Freeman, Essential Docker for ASP.NET Core MVC, London: Editorial Apress, 2017, pp 56-60.

J. V. Talledo San Miguel, UF1467 - Aplicaciones microinformáticas e internet para consulta y..., España: Editorial Paraninfo, 2016. pp.66-69.

K. S. Prasad Reddy, Beginning Spring Boot 2: Applications and Microservices with the Spring..., India: Editorial Apress, 2017. pp. 64-70.

B. Dayley, Node.js, MongoDB, and AngularJS Web Development, United States of America: Editorial Addison-Wesley, 2014, pp 39-54.

T. Hall and J.-P. Stacey, Python 3 for Absolute Beginners, United States of America: Editorial Apress, 2010, pp. 161-181.

L. Debrauwer and Evain, Patrones de diseño en PHP: Los 23 modelos de diseño: descripciones y ..., Barcelona: Eni Ediciones, 2015, pp. 25-35.

P. DuBois, MySQL Cookbook: Solutions for Database Developers and Administrators, United States of America: Editorial Oreilly, 2014, pp 233-256.

S. Haldar, SQLite Database System Design and Implementation (Second Edition, Version 1 ..., United States of America: Self - Publishing, 2015, pp. 40-45. 


\title{
Life Cycle Assessment of Msw Landfill Management Strategies in Colombia: Case Study
}

\author{
Paola A. Ramírez-Rodríguez*, John J. Sandoval-Cobo**, Ramón F. Colmenares-Quintero*, \\ Diana M. Caicedo-Concha*
}

Universidad Cooperativa de Colombia, Colombia

** ECCA Group, Faculty of Engineering, Universidad del Valle, Cali, Colombia

E-mail:

diana.caicedoc@campusucc.edu.co

\section{Introduction}

Final disposal of Municipal Solid Waste (MSW) in landfills is seen as the most commonly applied alternative for waste management in Colombia. According to the Superintendencia de Servicios Públicos Domiciliarios, in $201481 \%$ of the municipalities disposed their solid waste in landfills, $10.34 \%$ in waste dumps and $3.09 \%$ took them to recovery plants, whilst the remaining carried out another type of treatment [1]. Local public policies have had a positive impact on the environmental control of waste by regulating technical aspects for the construction and operation of landfills [2-4]. Technological options have emerged such as the collection, treatment and/or recirculation of leachates generated in landfills and the collection, burning and use of biogas for energy generation. This represents benefits for the protection of human health, the environment, and preservation of natural resources by reducing air, water and soil pollutants [5]. On the other hand, in order to comply with the environmental vision set out in the National Policy for the Comprehensive Management of Solid Waste, which proposes to move towards a circular economy, it is essential to select solid waste management scenarios that have lower environmental impacts [6]. In this study we aim to evaluate the environmental impacts of Msw final disposal technologies in a city, in order to establish the technological alternative with the best environmental performance using the Life Cycle Assessment (LCA) tool [7].

\section{Experimental}

The study area corresponds to a regional landfill located in Valle del Cauca, Colombia, which serves to more than 20 municipalities and receives approximately 760 tons/day of waste [8]. The region has an average annual precipitation of $1,597 \mathrm{~mm}$ and an average temperature of $21.3^{\circ} \mathrm{C}$. Due to the presence of a bi-modal period of precipitation in Colombia, monthly rainfall in the region can increase to $150-300 \mathrm{~mm}$ during the rainy seasons.

For the LCA, the phases considered by the international standards Iso 14040 and Iso 14044 were developed [9]. The Life Cycle Impact Assessment (LCIA) is currently applied using the ReCiPe method and a midpoint level. Most of the data used 
in this study was obtained from a field study in the landfill described. Information that was not available was adopted from the literature complying with the criterion of the best available information. Data of fuels, energy matrix, vehicles and machinery required for the LCA were obtained from the Ecoinvent database. All the scenarios were modelled using the Easetech software, developed by the University of Denmark -DTU, given its extensive use for LCA of solid waste management systems [10]. The functional unit defined for the study was of 1 ton of disposed solid waste. All materials and energy consumption are based on this functional unit. The scenarios considered were: (a) conventional landfill with leachate treatment; (b) landfill with leachate treatment and recirculation; (c) landfill with leachate treatment, recirculation and burning of landfill gas; and (d) landfill with leachate treatment, recirculation and use of landfill gas for energy generation. Operative factors such as collection, transport and pre-treatment of waste were not considered, whilst the adequation of dumping zones, required raw material, energy consumption and the technical conditions for the design of the areas in accordance with current legal regulations were analysed.

\section{Results and Discussion}

This study aims to advance in the development of the LCA as a methodology used for the evaluation of environmental impacts in different waste management scenarios in Colombia, therefore contributing with information about our local context and expanding research in this field. In terms of results, the (d) scenario is expected to obtain a net benefit. For those scenarios that include recirculation - (b) to (d)-, we expect to obtain results that show an increase in organic matter degradation capacity and reduction of emissions that pollute air, water and soil. We also expect that the results will help establish the best alternative for final Msw disposal and inform the decision-making level about environmental performance results.

\section{Conclusions}

The possibility of selecting a technological option for final Msw disposal is evaluated by measuring the environmental performance of different scenarios. The alternative with the least negative environmental impact will be considered as the best option. Part or the complete methodology can be replicated as baseline or as a tool to identify aspects to be improved through an informative feedback. Altogether, this study will improve LCA applicability as a tool for the evaluation of environmental impacts in MSW management in Colombia.

\section{Acknowledgements}

The authors want to express their gratitude to the Royal Academy of Engineering for financing the project "Identification of Knowledge Gaps in the Academia and Capacity Building for Aquatic Renewable Energy in Colombia"; to the Universidad Cooperativa de Colombia for financing the project INV1688 "Valorización de los residuos sólidos municipales a través de la producción de Biogás: estudio de la tecnología de Recirculación de Lixiviados (RL) en la operación de rellenos sanitarios contexto colombiano- para la aceleración de la degradación y la maximización de la producción de biogás"; and to the contribution of COST Action FP1306 that promoted networking and collaboration, as well as the support via STSMS.

\section{References}

Super Intendencia de Servicios Públicos Domiciliarios. Disposición final de residuos sólidos: informe nacional. Bogotá D.C., Colombia (2015).

Ministerio de Vivienda, Ciudad y Territorio. Reglamento técnico del sector de agua potable y saneamiento básico: título $f$. sistemas de aseo urbano. Bogotá D.C., Colombia (2012).

Ministerio de Vivienda, Ciudad y Territorio. Decreto 1077 de 2015 (may 26 $6^{\text {th }}$ ). Bogotá D.C., Colombia (2015).

Ministerio de Vivienda, Ciudad y Territorio. Decreto 1784 de 2017 (november 2nd). Bogotá D.C., Colombia (2017).

W. Xing, W. Lu, Y. Zhao, X. Zhang, W. Deng, \& T. H. Christensen. Waste Management, 33382 (2013).

Departamento Nacional de Planeación. CONPES 3874. Bogotá D.C., Colombia (2016).

A. Boldrin, T. L. Neidel, A. Damgaard, G. S. Bhander, J. Møller, \& T. H. Waste Management, 31619 (2011).

Super Intendencia de Servicios Públicos Domiciliarios. Disposición Final de Residuos Sólidos: Informe Nacional. Bogotá D.C., Colombia (2015).

Asociación Española de Normalización y Certificación. Gestión ambiental: Análisis de ciclo de vida, principios y marco de referencia ISO 14040:2006. Madrid, España (2006).

Denmark. Technical University of Denmark. Welcome to Easetech. Available: http://www.easetech.dk/ 


\title{
Incidence of Photovoltaic Cell Temperature in Energy Conversion for Silicon Panels
}

\author{
Leiny Ordoñez ${ }^{\star}$, Lisbeth Martínez ${ }^{* *}$, Ángela Aguirre*, Diego Hernández ${ }^{\star}$
}

Universidad Santiago de Cali, Cali Valle del Cauca, Colombia

** Universidad del Cauca, Popayán Cauca, Colombia

E-mail:

lmartinez@unicauca.edu.co

\section{Introduction}

$76.3 \%$ of the electricity around the world comes from non-renewable energy sources, as opposed to $23.7 \%$ that come from renewable ones. Of the latter, only 1.2 $\%$ is generated with photovoltaic solar energy [1]. Research in photovoltaic measurements has become a new area of interest, both internationally and nationally. In 2004, researchers from the Pontificia Universidad Católica in Rio de Janeiro studied the 11 cities with the highest solar radiation in Brazil to evaluate photovoltaic energy production by comparing hourly and monthly photovoltaic conditions [2]. Colombia has begun to do research on this topic. Proof of that is a study carried out by scholars from Universidad del Cauca who propose a mathematical model to simulate and implement an autonomous photovoltaic system based on performance models developed abroad with local photovoltaic conditions [3].

This research aims to reveal temperature impact on silicon photovoltaic cell panels developed from three different technologies: monocrystalline, polycrystalline, and amorphous, for the conversion of solar energy at its maximum power. This research implements the performance model created by David King, William Boyson and Jay Kratochvill from Sandia National Laboratories, USA, and it is based on hourly measurements of solar radiation, ambient temperature, and wind speed. This sort of simulation helps governments, companies, and investors make better decisions about energy production projects for this specific kind of renewable energy.

\section{Experimental}

Photovoltaic panel technologies

Table 1. Conversion efficiency according to technology type [4]

\begin{tabular}{|l|c|}
\hline \multicolumn{1}{|c|}{ Type of technology } & Efficiency reference \\
\hline Monocrystalline silicon & $25.6 \% \pm 0.5 \%$ \\
\hline Polycrystalline silicon & $20.8 \% \pm 0.5 \%$ \\
\hline Amorphous silicon & $10.5 \% \pm 0.3 \%$ \\
\hline
\end{tabular}




\section{Cell temperature mathematical model}

The numeric simulation implemented followed the model produced by David King, William Boyson, Jay Kratochvill. It uses the equation (1) to determine the temperature of the photovoltaic cell. In this model, the authors propose the values $\mathrm{a}, \mathrm{b}$ and $\Delta \mathrm{T}$ for different kinds of assembling and photovoltaic modules [5].

$$
T_{c}=G_{T} *\left\{e^{a+b * v}\right\}+\frac{G_{T}}{G_{r e f}} * \Delta T
$$

Key:

$G_{T}$ Incident solar radiation at the place where the panel is installed; $a$ : empirically determined coefficient that establishes the upper limit for the temperature module at low wind speeds and high solar radiation; $b$ : empirically determined coefficient that determines at which speed the temperature of the module increases; $V$ : wind velocity at the place of panel installation; $\mathrm{Ta}$ : ambient temperature; $G_{r e f}$ reference solar radiation of photovoltaic module $\left(1000 \mathrm{~W} / \mathrm{m}^{2}\right) ; \Delta T$ : temperature difference between the cell and the posterior surface of the photovoltaic module at a radiation level of $1000 \mathrm{~W} / \mathrm{m}^{2}$.

\section{Maximum energy obtained from photovoltaic conversion}

Using the equation below (2), the maximum energy obtained from photovoltaic conversion [6] may be found.

$$
E m p=\eta m p \cdot A c \cdot G t
$$

Key:

Emp: Maximum energy obtained from photovoltaic conversion; $\mu m p$ conversion efficiency at maximum power; $A c$ : solar panel area; $G t$ : incident solar radiation

\section{Methodology}

Based on the photovoltaic conditions supplied by the weather station PTAR (Wastewater Treatment Plant) from Cenicaña (Colombian Sugarcane Research Centre) in Cali, and on data supplied by photovoltaic panel makers, a statistical treatment of the data was done using Microsoft Excel and having a criterion for inclusion of hourly data showing the highest solar radiation (08:00 to 17:00), for a period of 12 months. Later, using Microsoft and the mathematical model previously mentioned, a numerical simulation was made to observe the incidence of cell temperature $(\mathrm{Tc})$ on energy conversion $(E m p)$ in silicon panels from the three different technologies.

\section{Results and Discussion}

The results show the dynamic behaviour of the cell temperature and the energy conversion per month. The following chart shows the photovoltaic cell temperatures in ${ }^{\circ} \mathrm{C}$ :

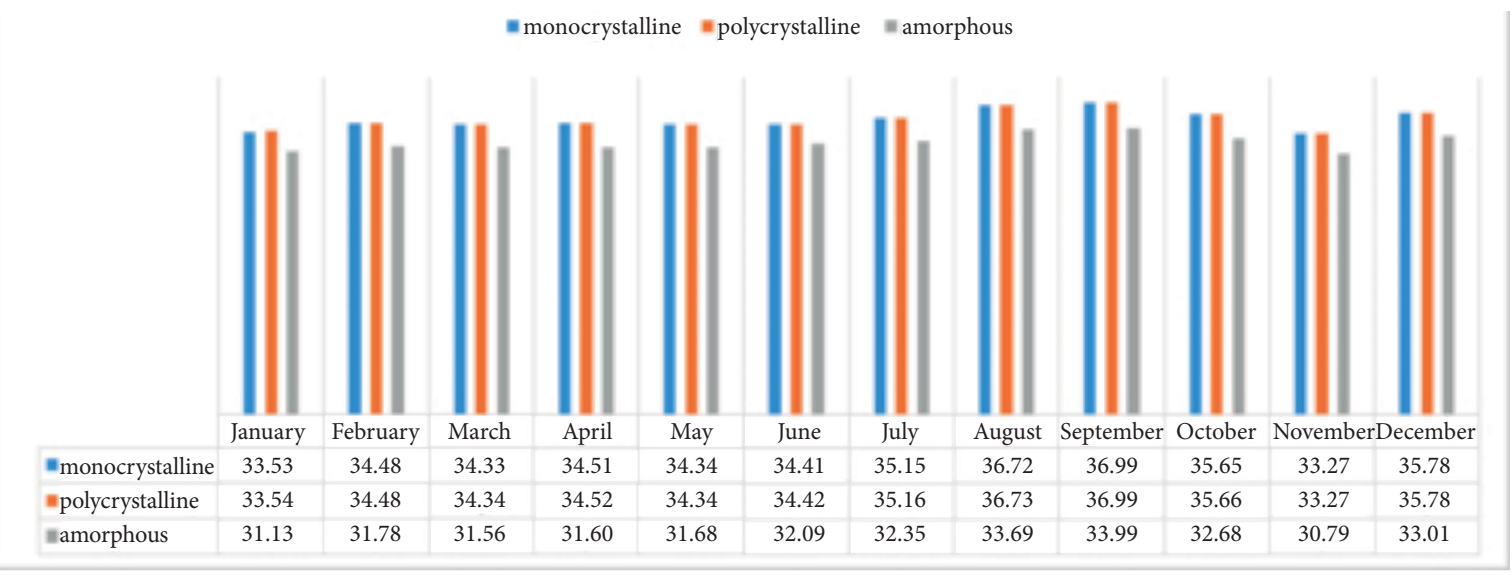

Figure 1. King model cell temperature 
Similarly, Figure 2 shows the energy $(\mathrm{W})$ converted at maximum power:

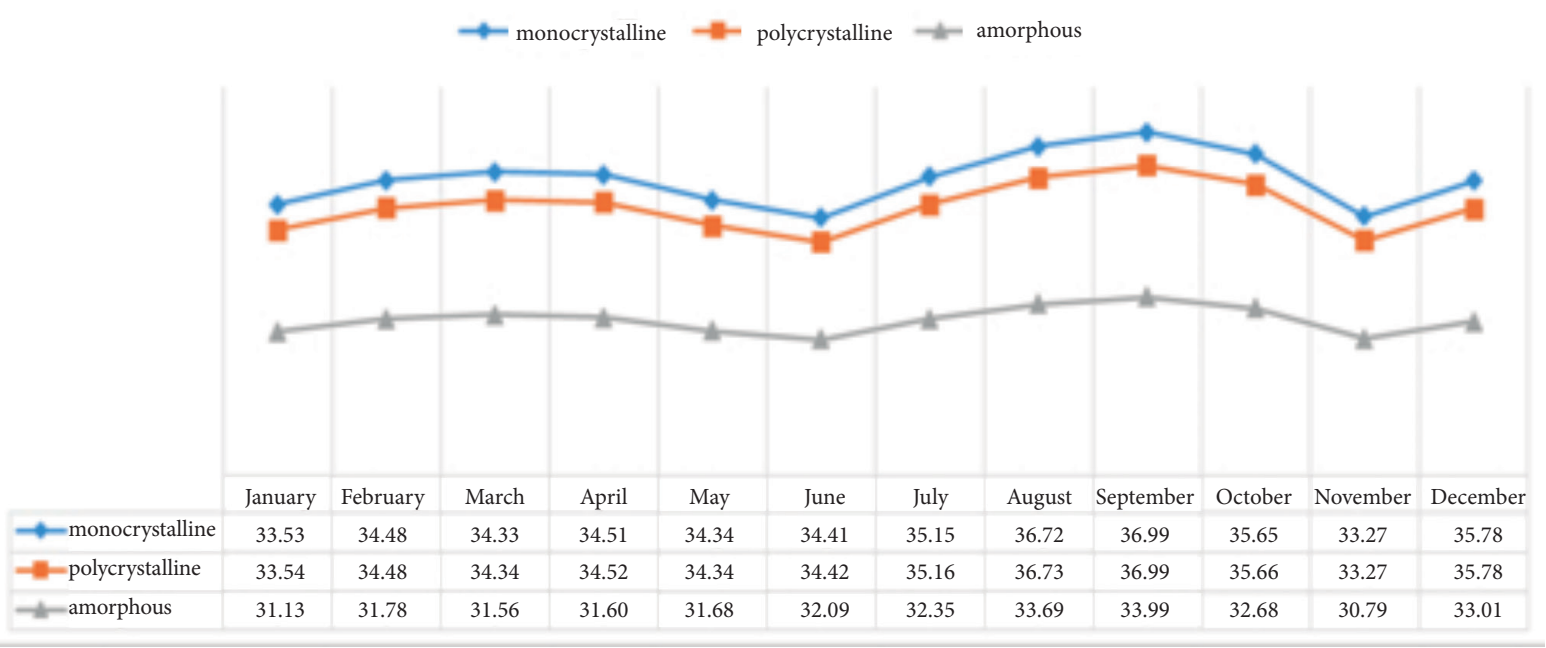

Figure 2. Energy converted king model

The graphics in Figure 1 show an increasing behaviour relative to the monthly average of ambient temperature on each of the three technologies evaluated under Cali's solar conditions. Ambient temperature reached its highest level in September $\left(29.18^{\circ} \mathrm{C}\right)$, which consequently produced the highest temperature values in cells $\left(36.99^{\circ} \mathrm{C}\right)$. The lowest levels were reached in November $\left(30.79^{\circ} \mathrm{C}\right)$.

As for energy conversion shown in Figure 2, the highest points were reached in September with all three silicon technologies: monocrystalline $(159.24 \mathrm{~W})$, polycrystalline (143.92 W), and amorphous (82.83 W).

\section{Conclusions}

Cell temperature is directly proportional to the energy produced by the panel. It is also affected by factors such as local solar radiation and panel area, both of which influence the amount of solar energy converted to electricity.

The results from this research prove quantitatively how Cali has the adequate solar conditions for investing and implementing photovoltaic energy as a complement for conventional energy sources.

The mathematical simulation used in this research is equally valid for any other city around the world, simply by introducing the necessary photovoltaic input: solar radiation, ambient temperature and wind speed.

\section{Acknowledgements}

To the Universidad Santiago de Cali and its Dirección General de Investigaciones (DGI), who funded this research. To Universidad del Cauca for the advice from metrology expert and the author of this text. To Cenicaña (Colombian Sugarcane Research Centre), that supplied meteorological measurements of Santiago de Cali.

\section{References}

Renewable Energy Policy Network for the 21st Century (2016) Reporte de la situación mundial de las energías renovables [Online] Available: http://www.ren21.net/ wp-content/uploads/2016/10/REN21_GSR2016_KeyFindings_en_10.pdf

L.L. Martinez. "Conversión fotovoltaica: Comparación de modelos de desempeño." Master Thesis, 2013.

E.D. Obando, R, Vargas, Rev. Acad. Colomb. Cienc. Ex. Fis. Nat., 4027 (2016).

M. Green, K. Emery, Y. Hishikawa, W. Warta, E. Dunlop, Prog. Photovolt: Res. Appl., 23805 (2015).

D. King, W. Boyson, J. Kratochvill, Photovoltaic Array Performance Model, 219 (2004).

J. Duffie, W. Beckman, Solar Engineering of Thermal Processes (Fourth ed.), 23755 (2013). 


\title{
A Comprehensive Solution Approach to the Sustainability Problem of Photovoltaic Systems: The Bolivian Case
}

\author{
Arturo Dávalos Yoshida*, Richard Gil Herrera*
}

Universidad Americana de Europa Unade, México, ABs Consulting Group, La Paz.

E-mail:

arturo.davalos@abs-cgroup.com

\section{Introduction}

According to the 2014 World Bank statistics, $14.7 \%$ of the total population did not have access to electricity. In the rural population, this percentage amounted to $27 \%$. In Bolivia, $28.5 \%$ of the total population did not have access to electric power. This situation is more serious in rural areas, beacuse most of Bolivian urban centres are provided with electric networks.

In order to address this situation, the governments of developing countries have made an effort to use new alternatives that technological advances allow. Thus, countries such as Bolivia, Argentina, Ecuador, Peru and Guatemala, which have state resources and international cooperation support, have recently started numerous programs and projects with solar photovoltaic systems (SFv) to provide electric access for rural population in need.

However, according to this research, Bolivian programs and projects so far, lack an integral sustainability scheme that guarantees permanent and continuous operation. Therefore, at present, there are important doubts about the effectiveness of these efforts to solve the problem of electric access.

The main objectives of this research are: i) Study the sustainability mechanisms considered in projects for provision of SFV in Bolivia; ii) Study comparative experiences and success stories in selected countries; and iii) Propose adjustments in the institutional and regulatory framework to generate a comprehensive sustainability system to implement SFV provision.

\section{Experimental}

To contextualize, recent and regulatory technical literature of the countries in question has been reviewed. This made possible to understand the scope of institutional and regulatory intervention. In addition, the results of solutions for access to electricity in remote rural regions in countries similar to Bolivia were analysed. The specific case study has been developed through the analysis of the different projects/programs of both State and other organizations for the electrical energy provision based on SFv for Bolivia's rural inhabitants. 
Once the programs/projects and the rural communities benefited were identified, a field study comprised of a series of interviews to the beneficiaries and an inspection of the operability of the installed SFV was conducted. In case the SFV was not working, this study identified the reasons and problems that could have caused its non-operation.

Likewise, cases of State or private intervention providing SFV and the sustainability schemes adopted there have been investigated internationally in selected countries (Argentina, Peru, Ecuador and Guatemala). The aforementioned countries were selected based on information availability, comparability level with the Bolivian case and implementation of international successful projects for solving the problem of poor electricity access in remote areas.

\section{Results and Discussion}

Through the study of the objectives and characteristics of the different programs/projects applied in Bolivia to provide electrical energy with small off-grid photovoltaic systems and with a research field in benefited communities, it has been possible to identify findings that allowed to identify interconnections.

The cabinet research and fieldwork in beneficiary communities has made it possible to identify that the projects and programs in Bolivia and in the other countries, have been conceived to deliver the SFV free of charge or with small counterpart contributions, under the assumption that the beneficiary would later carry out its operation and maintenance, at their own cost to guarantee its operation.

The research has established that although the beneficiary families value the new comforts achieved with the SFV, they are not prepared, both economically and culturally, to foresee important expenditures to replace costly items such as batteries, once they have reached their end of life. Another aspect that was not considered for the design of the sustainability schemes, was the inexistence of a spare parts market, as well as the technical services provision. In fact, in Bolivia, both aspects caused SFV to stop operating after these elements reached the end of useful life. Consequently, it is necessary to develop a sustainable scheme for this situation.

An integral approach implies to take into account the environmental component, although this type of equipment has a low polluting impact. It has been identified that the SFV delivery schemes did not contemplate a withdrawal system for the disused parts, leaving full responsibility to the families.

Similar situations have been identified in the other analysed countries. The applied solutions have been diverse. In Guatemala, a series of community intervention meetings has been adopted to establish and manage monthly contributions of beneficiary families for operation and maintenance. In Argentina and Ecuador, the electricity distributors are in charge of installing the SFv but the regular operation and maintenance is charged in a periodic fee that beneficiaries must pay. In Peru, companies that are in charge of the SFV installation and operation/maintenance in specific regions have been hired and charged a fee approved by the official regulator.

In Bolivia, the findings of this research have allowed to establish the comprehensive sustainability guidelines that covers regulatory - institutional, operational and financial aspects, which could be replicated in other countries with the corresponding customizations. In the next table we present the monthly payments calculated for the use of the SFV per country analysed.

Table 1. Estimated monthly tariffs paid by families in analysed countries

\begin{tabular}{|l|l|l|l|l|l|}
\hline \multirow{2}{*}{ Country } & Type of SFV (kWh / month) & $\begin{array}{c}\text { Subsidy } \\
\text { (UsD/Month) }\end{array}$ & $\begin{array}{l}\text { Paid by User } \\
\text { (UsD/Month) }\end{array}$ & $\begin{array}{c}\text { Total } \\
\text { (USD/Month) }\end{array}$ & \multicolumn{1}{|c|}{ Observations } \\
\hline \multirow{3}{*}{ Argentina } & 10 & 6.40 & 2.75 & 9.15 & Paid to system operator \\
\cline { 2 - 6 } & 15 & 9.38 & 4.02 & 13.40 & Paid to system operator \\
\cline { 2 - 6 } & 20 & 10.86 & 4.65 & 15.51 & Paid to system operator \\
\hline Ecuador & 19 & 1.49 & 1.46 & 2.95 & Paid to system operator \\
\hline \multirow{2}{*}{ Guatemala } & 10 & & 2.50 & 2.50 & Paid to the community board \\
\cline { 2 - 6 } & Pre payment per 15 & 10.39 & 2.59 & 15.00 & Paid to system operator \\
\hline Peru & 10 & 6.64 & 3.43 & 10.07 & According with the model results \\
\hline
\end{tabular}

Source: Own elaboration with information from various sources 


\section{Conclusions}

From the investigation and evidences found, it has been established that:

- In Bolivia more than 40 thousand SFv have been installed in the last 10 years under different schemes, including a free endowment to the counterpart contributions for up to $60 \%$ of the total cost of the equipment.

- More than $90 \%$ of the SFv installed four or more years ago are out of operation, fundamentally due to a lack of resources for replacing damaged parts and the absence of a market for parts and replacements.

- The SFv has elevated the quality of life of the benefited rural families by creating a scheme to pay a monthly fee that guarantees a nonstop operability of these technologies.

- The international experience shows similar findings to those of Bolivia. Currently, the solution imposed is SFV delivery under a form of services provision in which the user agrees to pay a periodic fee. This solution also seems to be the alternative for sustainability in Bolivia.

- The operation and maintenance costs can't be covered exclusively by the user, hence subsidy mechanisms are necessary. This occurs in all analysed countries, where subsidies for initial investment and operation costs have been detected. Likewise, a subsidy is currently applied to conventional electricity consumption of low-income families. At least, this subsidy must be replicated to SFv users to avoid claims due to discriminatory conducts.

- Normative and regulatory adjustments must be made to allow the intervention of a service operator and the State as regulator of this service.

\section{References}

R. O. Lafuente. (2017). CEDIB: La energía solar fotovoltaica en Bolivia. [Online] Available: https://cedib.org/wp-content/uploads/2012/03/04_La-energia-solar-fotovoltaica-en-Bolivia.pdf

NU. CEPAL (2016) Monitoreando la eficiencia energética en América Latina. [Online] Available: https://www.cepal.org/es/publicaciones/40505-monitoreando-la-eficiencia-energetica-america-latina

Gobierno de Guatemala, Ministerio de Energía y Minas. (2015). Diagnóstico del proyecto de suministro e instalación de sistemas fotovoltaicos en la comunidad de Chuaberená, Guatzilep, Cubulco, Baja Verapaz. [Online] Available: https://docplayer.es/70374906-Diagnosticodel-proyecto-de-suministro-e-instalacion-de-sistemasfotovotaicos-en-la-comunidad-de-chuaberenaguatzilep-cubulco-baja-verapaz.html

Secretaría de Energía. (2014). Estudios de factibilidad del abastecimiento eléctrico de la población rural dispersa con energías renovables en la provincia de MendozaArgentina. [Online] Available: http://scripts.minem. gob.ar/octopus/archivos.php?file $=7081$

S. Feron, H. Heinrichs and R. R. Cordero. Sustainability, 8 443 (2016).

Ministerio de energía y minería, Ex - secretaría de energía (2015). Informe de Auditoría: Proyecto de energías renovables en mercados rurales (PERMER). [Online] Available: https://www.agn.gov.ar/files/informes/2017_020info.pdf

OLADE Informe. (2013) Aplicación de responsabilidad social corporativa (RSC) en sistemas de energía rural en zonas aisladas. [Online] Available: http://www.olade. org/wp-content/uploads/2015/08/Informe-consolidado-RSC-Guatemala.pdf

Ministerio de Hidrocarburos y Energía, Viceministerio de Electricidad y Energías Alternativas. (2014). Plan Eléctrico del Estado Plurinacional de Bolivia 2025. [Online] Available: https://observatorioccdbolivia.files.wordpress. com/2015/08/peebol2025.pdf 


\title{
CFD Analysis of a Subsonic Air-to-Air Ejector: Influence of the Mixing Tube's Length on its Performance
}

\author{
Diana I. González-Arango ${ }^{\star}$, Jorge A. Sierra*, Diego A. Hincapié-Zuluaga*
}

Instituto Tecnológico

Metropolitano, Departamento de Mecatrónica y Electromecánica, Facultad de Ingeniería, Materiales Avanzados y Energía MATyER-

Línea de Computación Avanzada y Diseño Digital CADD, Medellín, Antioquia, Colombia.

E-mail:

dianagonzalez225028@correo.itm. edu.co

\section{Introduction}

In industrial processes, ejectors are very important devices used in extraction systems and atmospheric control, where due to air conditions, the implementation of traditional ventilation equipment such as fans and/or blowers is not feasible. The same happens in the plastic industry where ejectors are used to transport particulate raw materials. In ejectors, a high process efficiency is fundamental and may be achieved by selecting an appropriate mixing tube length that guarantees a homogeneous velocity profile and a high energy efficiency determined by the ratio between mass flow rate of suction and mass flow rate of dragging (drag ratio). These devices have been used in a wide variety of applications in the chemical processes industry, nuclear reactors and chillers. In the chemical processes industry, ejectors have been used to pump corrosive liquids, sludge, fumes or other dangerous fluids that are difficult to circulate with conventional methods. In nuclear reactors, they have been used to provide emergency cooling in the event of reactor failure. In power plants, they are used to remove non-condensable air-cooled condensers [1].

Ejectors have a simple construction, easy installation, low cost, and do not require periodic maintenance because they do not imply moving parts. They are also used in cogeneration systems, i.e., the recovering of residual energy from industrial processes. Its principle of operation consists of the injection of a fluid at high pressure (drag fluid), which when passing through a converging nozzle generates a suction pressure that affects a secondary fluid (suction fluid), causing it to take the direction of the primary flow combining, along the mixing tube, so as to be expelled later at atmospheric pressure.

Ejectors have become very popular in the industry, specifically in the fields of energy saving and gas emissions reduction [2]. Despite the advantages over conventional ventilation systems, their energy efficiency, characterized by the drag ratio, presents relatively low values. Their high applicability in the industry and low energy efficiency are reasons to keep looking for improved operation parameters. Currently, there is a need to design highly efficient industrial processes and to increase the control of industrial variables such as systems' velocity and pressure. These goals are achievable by determining the incidence of the geometry in the existing commercial 
ejector operation system. Specifically, in the length of the mixing tube, determined by means of CFD.

\section{Experimental}

Nowadays, the increase in the industrial processes' efficiency requires the application of flexible computational tools that allow to test, modify and analyse the different variables that influence the system's performance, hence reducing manufacturing times and testing costs [3]. This study aims to determine the effect of the mixing tube geometry on the device's performance. For this, a CFD (Computational Fluids Dynamics) simulation on ANsys Fluent 19.0 was performed, with the constant pressure mixing Ejector operating at a subsonic regime [4] and using air as the working fluid.

Initially, the geometric model of the existing commercial subsonic ejector was made through a computer-aided design (CAD) program in the Design Modeler module of the ANsys Workbench 19.0 software. This model had a mixing tube length of $36.06 \mathrm{~mm}$. Subsequently, four (4) ejector geometrical models were designed with mixing tube lengths of 219.5, 439, 658.5 and $1097.5 \mathrm{~mm}$. This test was done in order to contrast and determine which of these five (5) designs had the most efficient performance in terms of the drag ratio. When implementing Booleans extraction operations, the control volumes associated with the air volume occupied inside the ejector were created. Each geometry was meshed guaranteeing acceptable qualities in parameters such as obliquity, orthogonality and aspect ratio, ensuring the independence of the mesh. The simple algorithm was used for coupling the velocity and pressure equations. K-epsilon turbulence model, transient evaluation of the equations, standard initialization method, pressure-based solution and absolute velocity formulation [5-6] were used in order to determine the performance curves of the ejectors and determine the most efficient one.

Computational fluid simulation was performed on a computer with two Intel (R) Xeon (R) processors CPUE5-2667 $0 @ 2.90 \mathrm{GHz}, 64 \mathrm{bit}$ operating system and two graphics cards NVIDIA Quadro 2000 and NVIDIA Tesla C2075.

\section{Results and Discussion}

Table 1. Drag ratio for different lengths of the mixing tube

\begin{tabular}{|c|c|}
\hline Length $(\mathbf{m m})$ & Drag ratio $(\mathbf{W})$ \\
\hline 36.06 & 0,197486 \\
\hline 219.5 & 1,200571 \\
\hline 439 & 1,239590 \\
\hline 658.5 & 1,225217 \\
\hline 1097.5 & 1,150872 \\
\hline
\end{tabular}

\section{Conclusions}

The simulations using the computational fluid dynamics (CFD) allowed to understand the behavior of the fluid inside the ejector and to determine the numerical characteristic curves by changing the geometrical parameters and length of the mixing tube. The ejector with the highest operational efficiency found by modifying and analysing the incidence of the length of the mixing tube was the one with a length of $439 \mathrm{~mm}$. This length guarantees a homogeneous mixture of fluids, a better velocity profile and superior efficiency in terms of drag ratio.

This investigation demonstrates that the application of flexible computational tools allows the analysis and modification of different variables that influence system performance, such as geometrical parameters. The CFD simulation methodology is useful as a numerical validation.

\section{Acknowledgements}

I would like to express my gratitude to the MSc. Jorge Andrés Sierra del Río, and the MSc. Diego A. Hincapié Zuluaga for making this study's realization possible, for their patience, time, constant supervision and dedication. Also to the Instituto Tecnológico Metropolitano for the financial support. 


\section{References}

D. Sun and I. Eames, Journal of the Institute of Energy. 68 65 (1995).

J. Chen, S. Jarall, H. Havtun and B. Palm. Renewable and Sustainable Energy Reviews, 4967 (2015).

K. R. Hedges and P. G. Hill. J Fluids Eng, 96272 (1974).
J. H. Keenan, E. P. Neumann and F. Lusterwerk. J Applied Mechanics, 72299 (1950).

Mazzellia, Little, Garimella, and Bartosiewicz, International Journal of Heat and Fluid Flow, 56305 (2015).

D. Chong, M. Hu, W. Chen, J. Wang, J. Liu, J. Yan. Applied Energy, 13067 (2014). 


\title{
Long-Term Energy Storage Challenges for Solar Lighting Applications in Desert Environments
}

\author{
Thomas Samuel ${ }^{\star}$, Raphael Baillot ${ }^{\star}$
}

Sunna Design S.A, Centre de Services Technowest, Blanquefort, France

E-mail:

thomas@sunna-design.fr

\section{Introduction}

Recent advances in rechargeable battery technologies (the so-called secondary batteries) transform the actual context by offering reliable solutions to desert environments. But a wide range of battery chemistries and the option of a battery management system has made more complex the understanding of what really makes a difference in battery lifespan. An extensive research and development program has been undertaken during the last two years with a French Research Laboratory (Laboratory for Storage of Electricity [LSE] belonging to the National Institute for Solar Energy [INEs]). The objective was to find the most resistant battery chemistry for desert environments and improve its performance to reach the ultimate lifespan in extreme climate conditions. This paper presents accelerated aging test results and points out why Ni-MH technology has been selected because of its efficiency and compliance with Africa or Middle East desert operating conditions; also how it could it be well managed to double its chemical standard lifespan. Nowadays a solar battery is expected to almost achieve an unprecedented 10 -year service thanks to smart energy management.

\section{Experimental}

Several factors influence the operational characteristics of a battery and its life-cycle. Concerning solar-powered applications, three important factors have to be taken into account for battery management as listed hereafter:

- Battery temperature - Operating mode and storage conditions

- Depth-of-Discharge, DoD - Slightly related to the application (load) and battery technology

- Battery Management System: The charge and discharge management are key elements that ensures the battery cycle life. End-of-charge and end-of-discharge detection methods preventing overcharge and over-discharge phenomena.

When buying a deep-cycle battery specifically designed for solar applications, there are several factors that should be taken into account to determine the TCO 
of the battery life and help decision makers choose the most suited technology for their application:

- Selling Price. This is the first factor to dimension a solar-powered system. Depending on the manufacturer and the chosen technology, some low-cost technologies may have a technological dispersion much higher than 10 to $15 \%$.

- Voltage. The battery voltage topology must be considered to ensure it matches the system's requirements (solar module and load). In addition, it is important to note that aging can lead to voltage decrease thus invalidating the minimum voltage required for its application while rated capacity would still be sufficient.

- Depth-of-Discharge (DOD) and operating temperature range. As previously underlined, both factors are primarily affecting battery life service. The higher they are, the shorter the battery lifespan will be.

- Brand and worldwide availability. Choosing a battery from a world-famous company is important as end-users may benefit from the company's expertise and/or proven experiences on similar applications. A reputable company may also offer experiences as accelerated aging tests that guarantee the performance and lifecycle in a targeted and specific environment.

The choice of the storage technology is crucial as it is the weakest aspect of solar systems. This is why Sunna Design has chosen to challenge $12 \mathrm{~V} / 10 \mathrm{Ah}$ $\mathrm{Ni}-\mathrm{MH}$ technology under accelerated aging tests simulating environments where photovoltaic technology best performs. A comparative study has been launched on VRLA $12 \mathrm{~V} / 25 \mathrm{Ah}$ storage technologies that are widely used by Asian players to provide lowcost solar lighting solutions. Three accelerating factors have been chosen to perform this study:
- Deep cycling: $90 \%$ of Dod has been applied to NiMH and VRLA batteries to benefit from a tight system sizing in case of good results,

- A C/5 charge and discharge rate: an average of $2 \mathrm{~A}$ for $12 \mathrm{~V}$ solar lighting topologies has been considered reasonable given the fact that the system is sized by small mini-modules delivering no more than 2,2A at the maximum of its capabilities. Such rate involved 2,4 cycles per aging day.

- A temperature average: $45^{\circ} \mathrm{C}$ during day and night has been determined to simulate worst cases based on real temperature maximums observed in targeted countries.

\section{Results and Discussion}

Sunna Design investigated with CEA-INEs accelerated aging and performance tests on Ni-MH $1.2 \mathrm{~V}$ cells and $12 \mathrm{~V}$ batteries. Fig. 1 shows the results. Those results emphasize the need to pay attention to the methods used to detect the end-of-charge and prevent premature aging. It is also important to point out the strong influence of the combination of deep cycling and high temperature on VRLA battery. According to those results, vrla solar batteries reach their failure criteria (5Ah of rated capacity) in only 80 days with smart management. Standard management methods for VRLA are based on voltage threshold (High Voltage Disconnect) regarding end-of-charge. As for Ni-MH technology, standard management induces a 258 days of service life under the same aging conditions. By using Sunna management system, a 9,37 years of service life is expected (through linear extrapolation) considering the same failure criteria as VRLA batteries, i.e. a $5 \mathrm{Ah}$ threshold of rated capacity. 


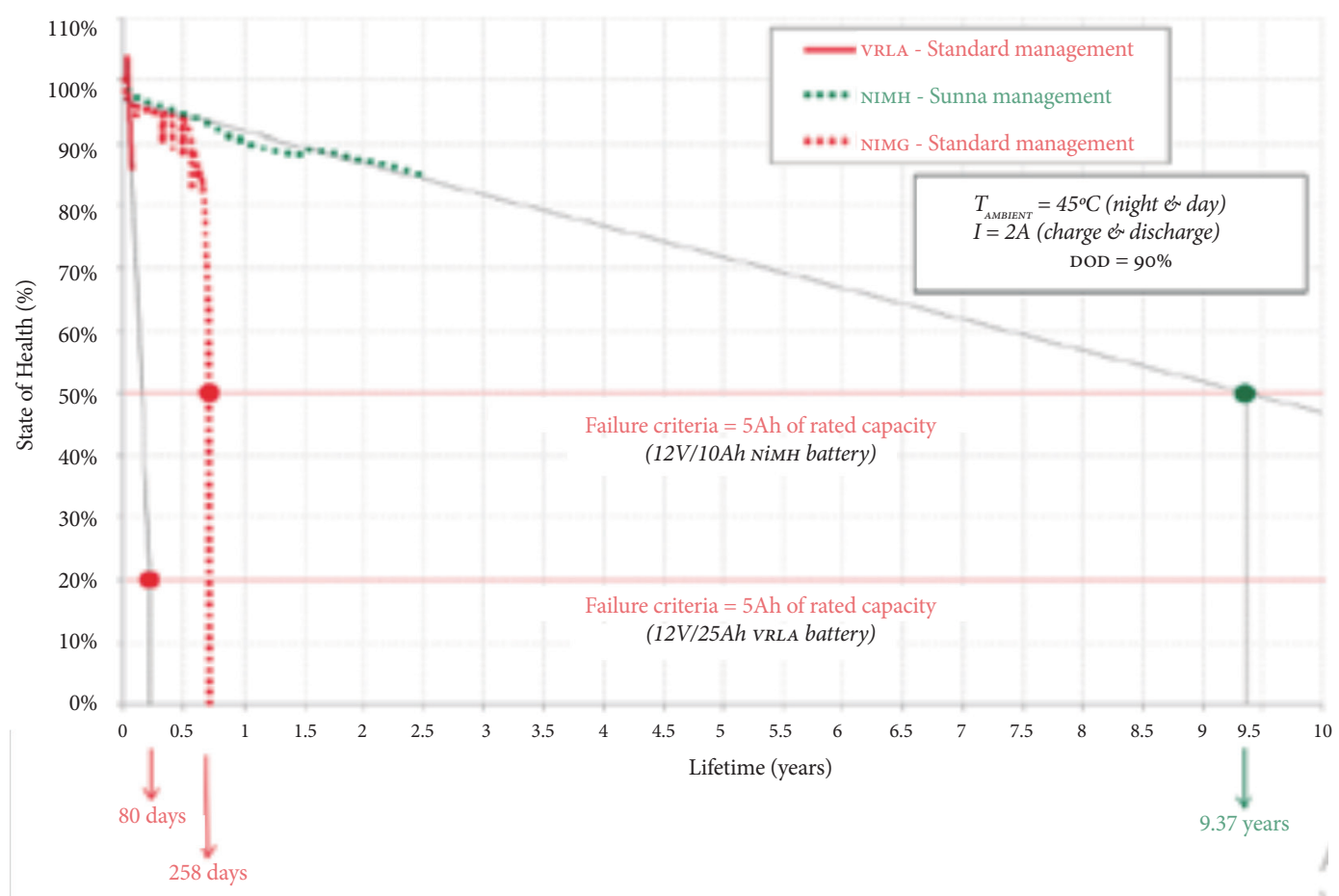

Figure 1. Comparison of VRLA and Ni-MH batteries accelerated aging tests ( $45^{\circ} \mathrm{C} / 2 \mathrm{~A}$ rate $/ 90 \%$ of DOD) by using standard management (30\% of overcharge) and Sunna management (overcharge avoided)

\section{Conclusions}

- A smart Battery Management System is the key point for ensuring the battery lifespan. Sunna Design expects a 10 years Ni-MH life service for solar street lights in a "desert environment".

- Lithium batteries have still major safety issues to overcome before being compliant with hot and dry "desert environments".
- Lead-acid batteries need to be well managed (smart BMs) and heat protected to comply with solar applications in "desert environments".

- Ni-MH is the most suitable storage technology for long term solar applications submitted to high temperature (up to $70^{\circ} \mathrm{C}$ ) and desert environments. 


\title{
Bold Incidence of the Geometry in Air Demand of Free Surface Discharge Conduits using CDF
}

\author{
Mateo Del Gallego*, Jorge Sierra*, Diego A. Hincapié*
}

Instituto Tecnológico

Metropolitano, Medellín, Colombia E-mail:

mateodel205229@correo.itm.edu.co

\section{Introduction}

The correct designing of free surface conduits with vertical gates is very important for electric energy generation dams as it prevents cavitation, structural vibration and cost overruns. In particular, in free surface flow discharge conduits it is necessary to incorporate artificial aerators, especially in low pressure zones down the gate where the speed of the flow inside the hydraulic conduits can increase the risk of structural damages. With the use of aerators, this effect is completely or partially compensated and the amount of cavitation generated over the gate is suppressed or reduced to permissible levels, preventing the deterioration of hydraulic structure.

Despite that a wide variety of hydroelectric projects have been developed in Colombia, some incidents have occurred relating to the expected and real air demand in discharging vertical gates; which result in a relevant affectation for the environment. The main problem for determining air demand ratio of vertical gates has been studied by many investigators, but due to the complex mathematical methods that describe the multiphase flow interaction phenomenon used to deal with the problem, they have had poor accuracy.

Traditionally the design of aeration systems for flow discharge conduits was done with physical scale models in laboratories, which produced different empirical formulations. The problem with these approximations consists on the inherent differences in a scale prototype, a real model and the geometric characteristics of the structure.

Currently, [1-2] are used in many cases to determine the air demand because these are usually exaggerated. [3] makes a sizing of the aeration system with spillway in different models, all in terms of depth flow and Froude number. [4] determines that the air demand in the design of new aerators is difficult to approximate without an experimental model and suggests that more data needs to be gathered in a future to understand the incidence of scale in spillway models. Ismail [5] develops the calculus of down pull forces on a vertical gate to modify characteristics of the gate and its variations. [6] discretized three flow regimes down the gate: fully water filled cavity, partially filled cavity and fully air cavity. The appearance of each depends on the Froude number and determines air dissipation. [7] studies the double free surface discharge using natural element discretization employing a radial 
gate, and compares the results obtained to an experimental model; the concordance is satisfactory. [8] determines the optimum air demand ratio in a circular conduit and concludes that the optimum Froude value on those conduits is 23 to 35 for the aeration demand.

\section{Experimental}

Computational methods allow to solve equations for a real scale model to obtain more accurate results and therefore, a better description of the pressure and velocity fields. The main objective of this study is to determine the incidence of the geometry hydraulic channel, especially of the angle of discharge downstream of the vertical gate, in the air flow demanded by the aeration system, and compare the analytical and computational methods in order to characterize the effect of the geometry in empirical equations found in literature for different operation conditions. The numerical simulation was performed in ANSYs Fluent. In this way, the velocity and pressure fields, flow and volume fraction of water and air were obtained. To solve water-air interface, the volume of flow method (Vof) was used in open channel mode in a sharp/dispersed configuration. For the viscosity model the ssт k-omega was implemented.

\section{Results and Discussion}

The results shown by computational fluid dynamic simulation (CFD) demonstrate that aeration demand is highest when the gate aperture is minimum and the pressure rises. Likewise, in all the cases developed, the angle of discharge is less significant than the aperture-pressure relation variable, similar to the analytic results obtained when the angle is not considered to solve the empirical equations.

\section{Conclusions}

The use of CFD simulation produces more trustworthy results without complications that analytical methods usually have. CFD suppresses the problem of the scale in the model and allows testing many operation conditions that in the laboratory would be impossible. The principal difference between these two methods is that in the analytic method, the air flow $(\mathrm{Q} a) /$ water caudal $(\mathrm{Qw})$ (Beta coefficient $\mathrm{Qa} / \mathrm{Qw}$ ) was much bigger than the Beta coefficient obtained by CFD method.

\section{References}

A. A. Kalinske and J. M. Robertson. Journal of Hydraulic Engineering, 1081435 (1943).

H. R. Sharma. Journal of Hydraulic Engineering, 1021630 (1976)

H. Chanson. Journal of fluids Engineering, 112343 (1990).

M. H. Chanson. Journal of hydraulic research, 33361 (1995).

I. Aydin, I. T. Telci and O. Dundar. Journal of hydraulic research. 44822 (2006).

A. Mohaghegh, J. Wu. Journal of Hydrodynamics, Ser. B, 22 726 (2010).

F. Daneshmand, S. A. Samad, J. F. Adamowski, T. Liaghat, M. Mohsen. Canadian journal of civil engineering, 39 643 (2012).

F. Ozkan, M. C. Tuna, A. Baylar, M. Ozturk. Water Sci Technol., 70871 (2014). 


\title{
Design of a Wind Rotor for a Wind Pump
}

\author{
Fabián Solano*, Sandra Cuervo-Andrade ${ }^{\star}$
}

Universidad Pontificia Bolivariana, Santander, Colombia

E-mail:

andres.solano.2014@upb.edu.co

\section{Introduction}

The use of wind turbines as an energy source has increased over the years. Its importance in the transition from fossil fuels to renewable energies is notorious, mainly in non-interconnected areas [1]. From about the $2^{\text {nd }}$ millennium $\mathrm{BC}$ to date, the technological and engineering advances in the design and construction of the turbines components have allowed to reach in 2016, a capacity of $460 \mathrm{GW}$ from wind energies [2]. In consequence, this study desires to design and install a wind rotor in the Guajira department in Colombia, taking advantage of its high potential of wind resource. The wind rotor will be connected to a pumping mechanism that will supply seawater for 1,218 people who suffer from a great water shortage in non-interconnected areas of the country.

\section{Experimental}

The methodology used in the design of the rotor is shown in figure 1. According to the World Health Organisation (wHO), the basic water consumption per person per day is $20 \mathrm{~L}$. However, this amount is not sufficient to prevent affections in people's health [3]. In this sense, the flow requirement for the pump was determined for a consumption per person of $30 \mathrm{~L}$ per day for a population of 1,218 people. Using NASA's tool Power, historical records of the territory's wind potential were obtained. 


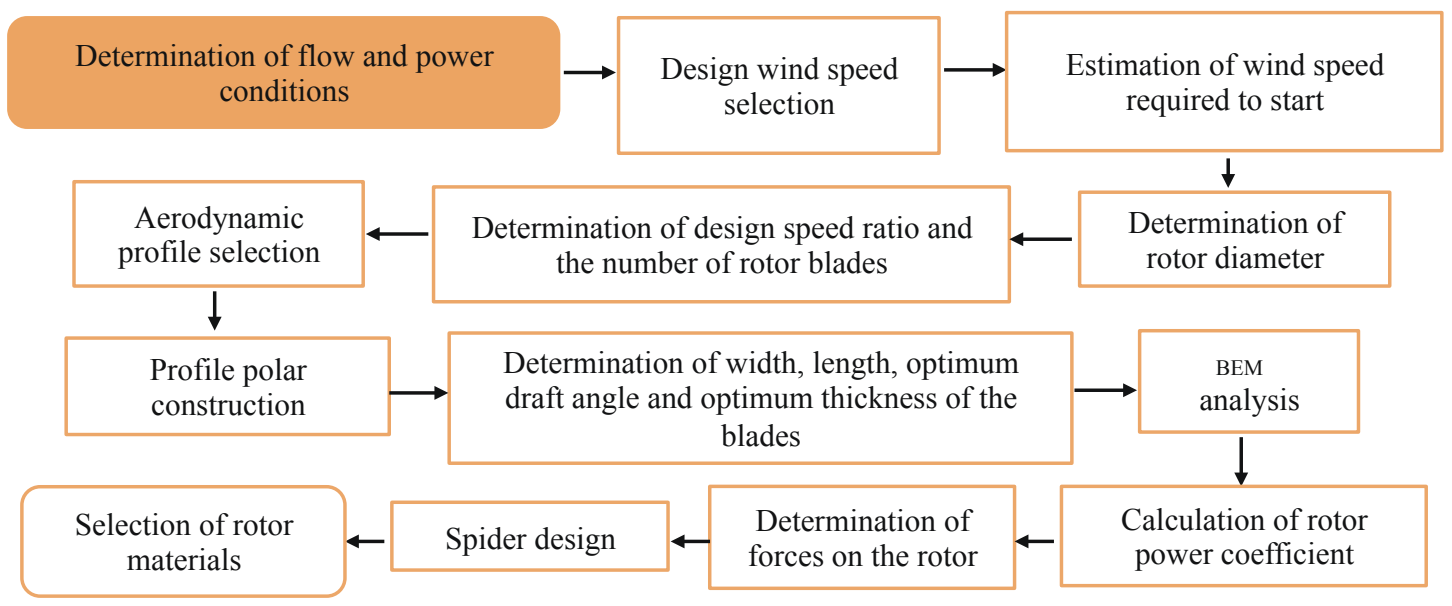

Figure 1. Flow diagram rotor design

The rotor dimensions were developed by analysing blade elements, with the help of Le Gourières turbillonary theory [4] and correlations for simplified blades [5]. The implementation of software: XFLR5, SolidWorks and Ansys was also important.

\section{Results and Discussion}

The specifications of the designed rotor are shown in table 1 . The average wind speed obtained was $8 \mathrm{~m} / \mathrm{s}$, which is in accordance with the minimum wind speed needed to run the rotor of $3.3 \mathrm{~m} / \mathrm{s}$. The rotor will then move a piston pump that according to its sizing, will allow a water flow through the system of $0,423 \mathrm{~L} / \mathrm{s}$.

From the calculations made with the blade element method [6], and according to the design conditions, the distance between the blades and the rotor hub was determined $(0.5 \mathrm{~m})$, with a draft angle (fixed) of $32^{\circ}$. The material for the blades and for most of the important components in the spider was chosen to be stainless steel AISI 304 . The design of the rotor without blades (spider) and with blades designed with the SolidWorks software is shown in figure 2 .

Table 1. Rotor specifications

\begin{tabular}{|l|l|l|l|l|l|}
\hline Diameter $(\mathbf{m})$ & $\mathbf{N}^{\circ}$ Blades & \multicolumn{1}{|c|}{ Aerodynamic airfoil } & Blade length $(\mathbf{m})$ & Design speed ratio & $\begin{array}{c}\text { Maximum power } \\
\text { coefficient }\end{array}$ \\
\hline 2.5 & 18 & Curved sheet $(5 \%)$ & 0.75 & 1.0 & 0.30 \\
\hline
\end{tabular}



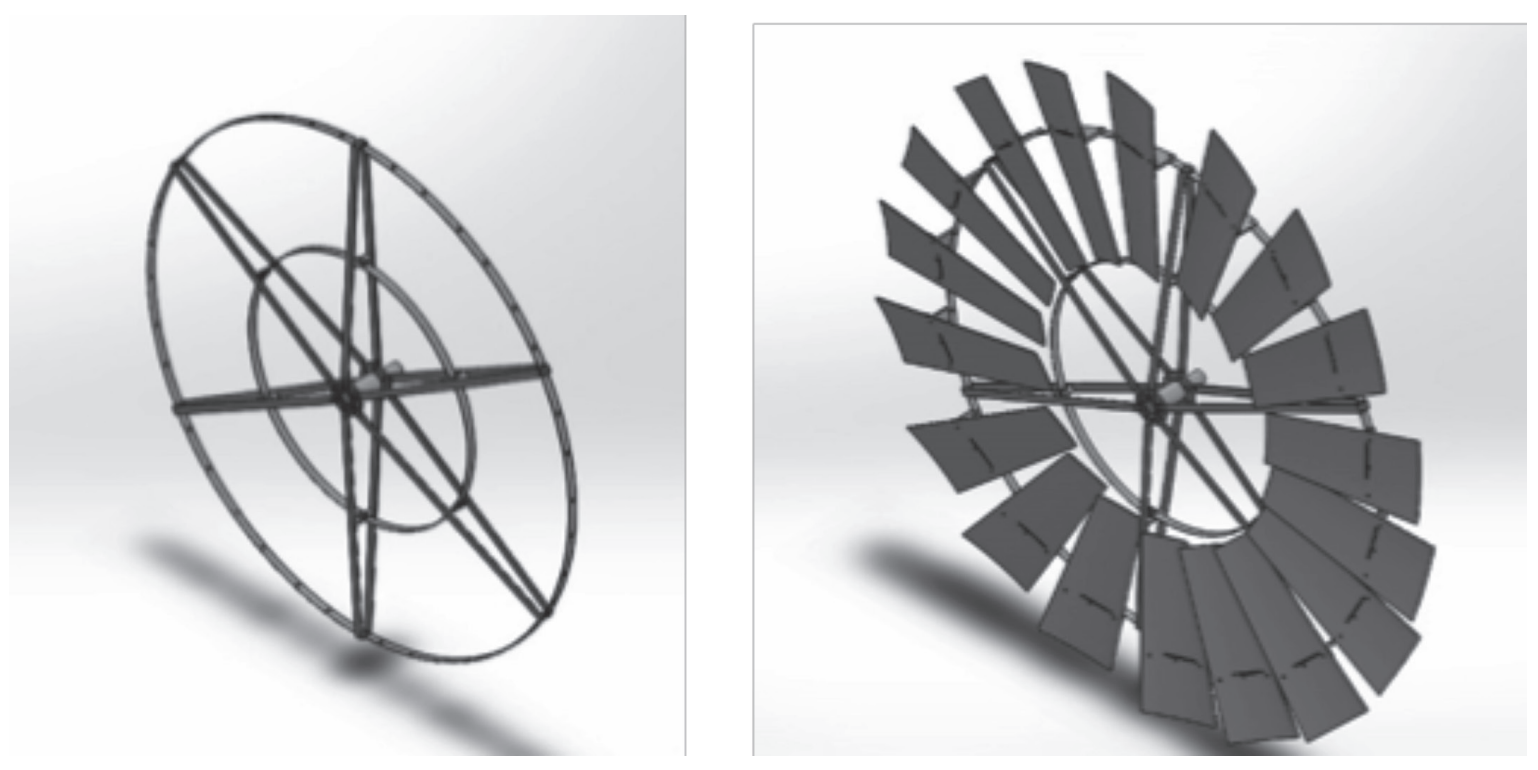

Figure 2. Rotor made in SolidWorks

\section{Conclusions}

The design of the American Multibladed-type rotor is optimum for the fulfilment of the present needs, due to its simplicity, low-cost, efficiency, easy and infrequent maintenance, and long utility lifespan. The rotor is capable of generating $470 \mathrm{~W}$ power at an incident wind speed of $8 \mathrm{~m} / \mathrm{s}$.

\section{References}

P. Brøndsted and R. Nijssen, Advances in wind turbine blade design and materials. Cambridge, UK: Woodhead Pub, 2013.
B. Griffa and L. Marcó, «Actualidad de la energía eólica a nivel mundial: generación, fabricantes, comercio exterior y precios.», Unsam.edu.ar, (2018). [Online]. Available: [Accessed: 07- Sep- 2018].

Who.int, (2003). «OMS | La cantidad de agua domiciliaria, el nivel del servicio y la salud», [Online]. Available: http://www.who.int/water_sanitation_health/diseases/wsh0302/es/.

D. Le Gourieres and E. Bollina, Energia eolica. Milano: Masson Italia, 1985.

M. Franquesa, Introducción a la Teoría de las Turbinas Eólicas, Castelldefels, 2009.

T. Letcher, Wind energy engineering. Academic Press, 2017. 


\title{
Design of a Photovoltaic System for the Coffee Drying Process
}

\author{
Irlesa S Sánchez ${ }^{\star}$, Carlos Castro*, Jaime Cabrera*, Ferley Medina*, Cristian Sterling*, \\ Santiago Yunda*
}

Universidad Cooperativa de Colombia, Colombia

E-mail:

irlesa.sanchez@campusucc.edu.co

\section{Introduction}

Coffee drying is a crucial process in the coffee value chain because of its influence on the quality of the final products. At present, solar drying is the most common traditional, economic and ecological practice used by Colombian producers according to the quality standards demanded by the National Federation of Coffee Growers (FNC). In the Corregimiento of San Andrés, there are single-mother households that carry out the process of coffee drying in very distant places. The difficulty to move from the farm to the main drying location has sometimes led to partial loss of their production and in some cases, to health affections.

Some producers have built coffee dryers with 8-gauge plastic structures in guadua. This system has allowed them to reach temperatures above 50 degrees Celsius, with the difficulty that brings having to eliminate the grains and expose their bodies to such temperatures; some already suffer from joint pains and constant headaches from thermal shock. The useful life of these artisan drying systems is in average, 2 years. This lifespan is reduced due to global warming and the presence of heavy winds in the region. Therefore, the design of a photovoltaic prototype for the drying of coffee in the Corregimiento of San Andrés that will benefit 22 women who live from this activity is proposed. In the experimental part of the research, the formula used with the respective material for each proposed prototype is presented. In the results, the design of each prototype is shown according to photovoltaic and photo thermal solar energy. In conclusion, the design of the photovoltaic prototype for the drying system will benefit coffee producers because of its reliability in terms of environmental care. 

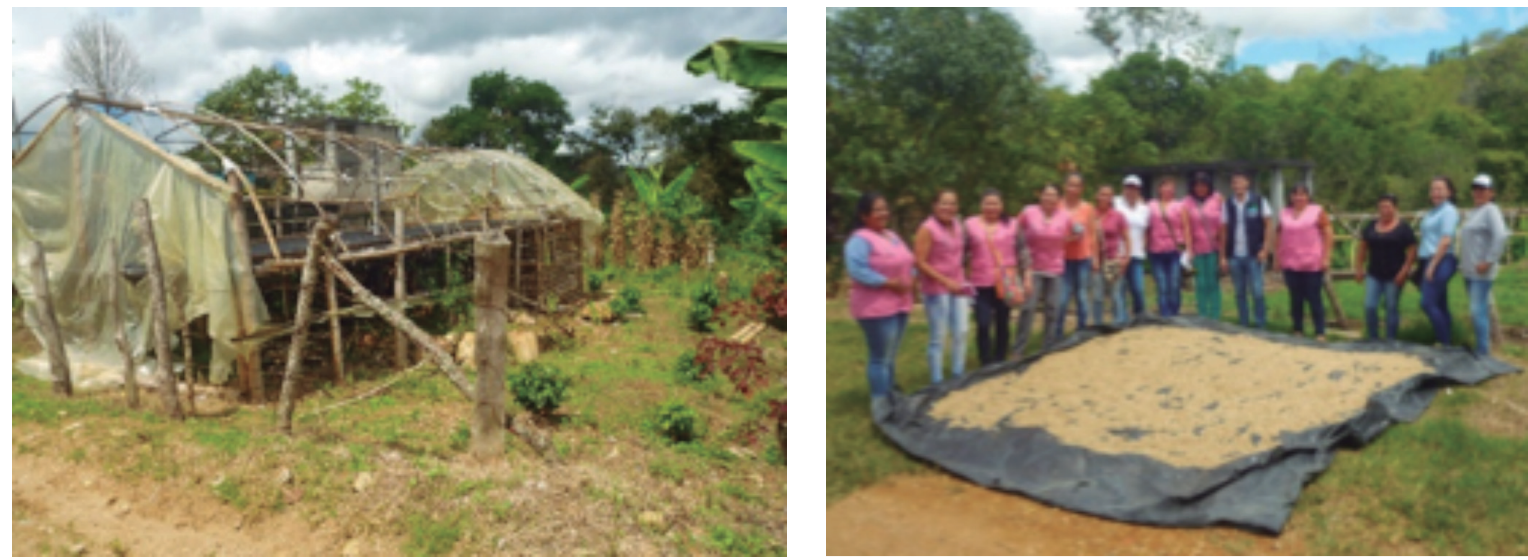

Figure 1. Artisan drying

\section{Experimental}

In the construction of the photovoltaic solar system, the basic mathematical calculations are taken as reference, knowing the technical specifications and the dimensions of each equipment with their respective accessories. The foregoing presents three prototype alternatives according to the production type. The formula used for the design was:

Drying efficiency: Wo is the initial weight of the product $(\mathrm{kg}), \mathrm{Wf}$ is the final weight of the product (kg), Lv the latent heat of water vaporization for the outlet temperature $(\mathrm{kJ} / \mathrm{kg})$, I is the irradiation for a specific time duration and Ac is the collection area.

$$
N=\frac{\left(W_{o}-W_{t}\right) L_{T}}{I A_{C}}
$$

\section{Prototype 1 elements}

The coffee drying prototype No. 1 must contain a highly strong plastic with a minimum of 8-gauge that allows an adequate behaviour at high temperatures. This prototype is based on the observations made in field research, it was built with two tables with dimensions of approximately $4 \mathrm{~m} \times 2 \mathrm{~m}$. For the duct system, it is recommended to use galvanized steel, reinforced aluminium or fiberglass because it must withstand temperature ranges of up to $60^{\circ} \mathrm{C}$. The linear duct distance is estimated from 15 to 18 meters. The photovoltaic solar system contains solar panels whose power range between $270 \mathrm{~W}$ (60 cells) to $340 \mathrm{~W}$ (72 cells) with efficiencies higher than $17 \%$ per module in polycrystalline or monocrystalline cell technology. The charge controller must allow the connection between the panel system and the battery bank with efficiency higher than $90 \%$ in MPPT technology. It is recommended that the batteries are of AGM- or GEL-type and stored in a cool and safe place, taking in consideration the local weather conditions. It is noteworthy that the solar collector's purpose in the present prototype is to heat the air entering the system. The air passing through will be driven by a small motor powered by the photovoltaic solar plant. The solar collector dimensions can vary according to the desired temperature requirement.

\section{Sizing of the photovoltaic solar plant:}

For the design of 6 solar panels from $280 \mathrm{~W}$ to 60 polycrystalline cells:

- Panel power: $280 \mathrm{~W}$

- Open short-circuit voltage (Voc): $39 \mathrm{Vdc}$

- Intensity in short circuit: $9.25 \mathrm{~A}$

An array of three solar panels in series and two parallel panels is calculated.

Arrangement of three panels in series:

3 (panels) x 39 (volts each) $=117 \mathrm{Vdc}$

Arrangement of two parallel panels in:

2 (panels) $\times 9.25$ (volts each) $=18.5 \mathrm{~A}$ 
After carrying out the previous calculations for the arrangement of the six solar panels, it is made evident that we require a charge controller that supports $117 \mathrm{Vdc}$ inputs and $18.5 \mathrm{~A}$, considering a safety margin of $15 \%$ minimum in each value of voltage and current. The batteries can be operated in ranges from $100 \mathrm{Ah}$ to $250 \mathrm{Ah}$, the amount required is subject to coffee drying times.

\section{Prototype 2 elements}

The coffee drying prototype No. 2 must contain a highly strong plastic of a minimum of 8 -gauge that allows a suitable behaviour at high temperatures. On the inside, the dryer supports up to 12 tables with dimensions of approximately $4 \mathrm{~m} \times 2 \mathrm{~m}$. For the duct system, it is recommended to use galvanized steel, reinforced aluminium or fiberglass, as it must withstand temperatures as high as $60^{\circ} \mathrm{C}$. The linear distance in ducts is estimated to be 50 to $60 \mathrm{~m}$. The photovoltaic solar system contains solar panels whose power range between $270 \mathrm{~W}$ and $340 \mathrm{~W}$ with efficiencies higher than $17 \%$ per module in polycrystalline or monocrystalline cell technology. Nevertheless, panels of $340 \mathrm{~W}$ (72) cells are recommended because of their reduced dimensions $(2 \mathrm{m \times 1} \mathrm{m})$ as according to the manufacturer. For the charge controller, the panel system and the battery bank must be connected and it must display efficiency higher than $90 \%$ in MPPT technology. It is recommended that the batteries are AGM- or GEL-type and stored in a cool and safe place taking in consideration the local weather conditions. It is noteworthy that the solar collector purpose in the present prototype is to heat the air entering the system. This air will be driven by a small motor powered by the photovoltaic solar plant. The solar collector dimensions can vary according to the desired temperature requirement. The calculations for the photovoltaic solar prototype No. 2 should be done according to the values of the technical sheet of the solar panel and following the procedure of the previous prototype.

\section{Prototype 3 elements}

The coffee drying prototype No. 3 must contain a highly strong plastic with a minimum of 8 -gauge that allows an adequate behaviour at high temperatures. The design contains three trays and has the option of including more. The trays are located vertically with dimensions of approximately $1.5 \mathrm{~m}$ x $1.5 \mathrm{~m}$. For the duct system, it is recommended to use galvanized steel, reinforced aluminium or fiberglass, as it must withstand temperatures up to $60^{\circ} \mathrm{C}$. The ducts must allow bringing the hot air from the solar collector through the entire tray area where the coffee is dried. The solar collector dimensions may vary according to the desired temperature requirement.

\section{Results and Discussion}

The design development adopts the measure of packages used in coffee production. One package is equivalent to 100 pounds and one ton is equivalent to 20 packages. Three (3) prototypes for coffee drying were proposed. They use solar energy for their operation or a combination of solar photovoltaic and photo thermal energy, in which the solar collector absorbs the rays of the sun, transforming them into heat energy, and generating a column of hot air and photovoltaic solar energy in which electricity is obtained from the sun's rays to energize the motors and / or fans in the ducts.

\section{Prototype No. 1}

It contemplates the two types of solar energy mentioned above that interact with each other to perform the drying function. They only work during the day. It contains a traditional greenhouse, with its plastic and tables to place the coffee that is going to be dried. Ducts are added to transport hot air into the interior, generating an air column that allows coffee to be dried more quickly and from various angles, as shown by the red arrows in the following figure. The external part of the greenhouse is made up of two systems: the solar thermal system composed of a solar collector and the photovoltaic solar system that is in charge of generating electricity and storing it in batteries. The photovoltaic solar system is made up of solar panels, a charge controller that has the function of regulating the charge or filling of the batteries. A battery arrangement as mentioned and a pure wave inverter are required, that allows us to convert energy in direct current (DC) to alternating current (AC). The ducts contain a ventilation system that will be energized by means of the energy stored in the batteries, with the purpose of driving the column of hot air generated by the solar collector. The solar collector allows the production of a column of hot air that will be driven by the ducts and the ventilation system to the interior of the greenhouse. 


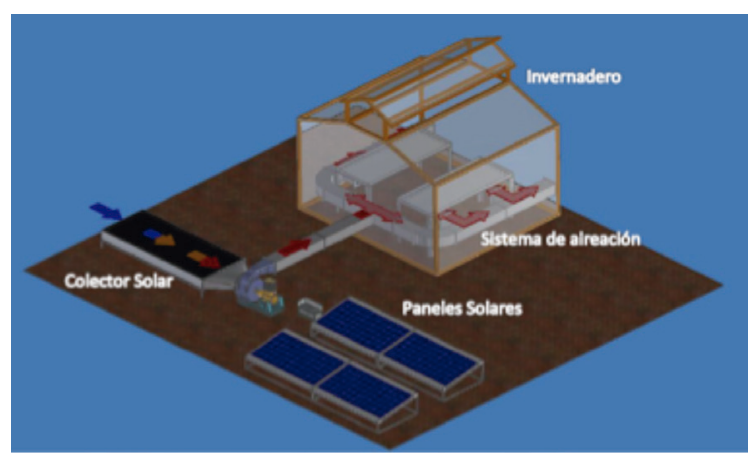

Figure 2. Prototype Drying System No.1

\section{Prototype No. 2}

It is similar to prototype 1 but on a larger scale for drying in the greenhouse, making the respective designs of solar thermal and photovoltaic energy according to factors such as temperatures, amount of solar irradiation per day and during the year, quantity of space required for its components and the greenhouse, among other considerations.

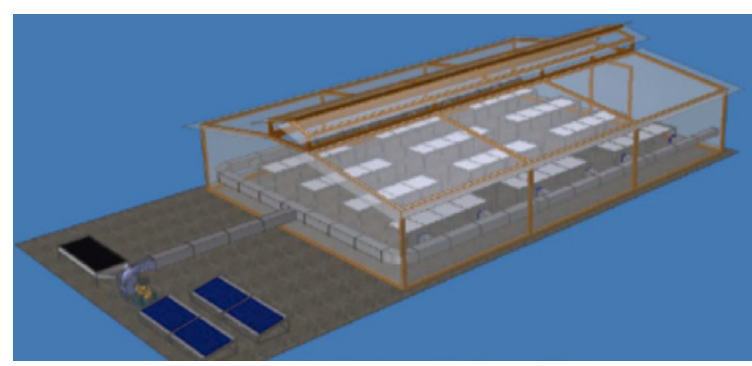

Figure 3. Prototype Drying System No. 2

\section{Prototype No. 3}

For this prototype, only solar thermal energy is used by means of the greenhouse plastics and the solar collector with its hot air column. It contains trays placed vertically, making use of less space in the greenhouse as it can be seen in Fig. 4. The trays can be removed to replace the coffee that has already dried, with one that needs to be dried in the greenhouse.

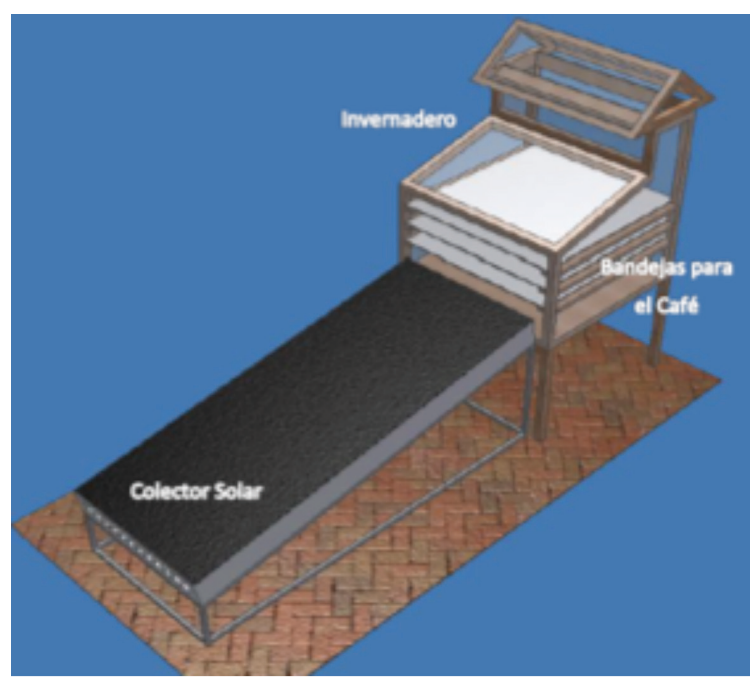

Figure 4. Prototype Drying System No. 3

\section{Conclusions}

Solar thermal energy uses the sun's energy to produce heat for the functioning of the prototypes by generating columns of hot air. On the contrary, photovoltaic solar energy allows solar radiation to be harnessed in the production of electricity through a semiconductor. Farmers will improve coffee production with the system previously exposed.

The proposed prototypes will allow female coffee producers to select the smaller scale, in case their production is in packages, and the larger scale for those who produce by tons. With the development of these new technological trends in the field of clean and renewable energies, it is possible to reduce $\mathrm{CO}_{2}$ emissions, the main precursor of the greenhouse effect. They are also systems that, in addition to evidencing energy savings, are scalable and reliable. They allow a corporate recognition for the use of these energy sources and may even be candidates for tax benefits from the local government.

The development of these prototypes allows to open new windows in research on various areas of knowledge and to improve technologies that care for the environment. 


\section{Acknowledgements}

Coffee women of the corregimiento of San Andrés, municipality of la Plata; Knowledge Managers Program Agreement 218 under the 002 call; Support from experts of the company Greencol Energy s.A.s.

\section{References}

S. Camacho and O. Ramirez. Design of a coffee dryer by heating the air in two stages using solar energy. Rodrigo Facio University City: University of Costa Rica. (2015).

Cceea. "Photovoltaic solar energy (Autonomous Systems)." Available: https://cceea.mx/cursos/energia-solar-fotovoltaica-sistemas-autonomos/ [Feb. 20, 2015].

Cenicafe. Primer 21: Benefits of coffee II: Drying of parchment coffee. Bogotá: Cenicafe, 2012.
Fedecafe. "Drying of coffee, another key for Colombian Coffee to be of high quality." Available: http://www. cafedecolombia.com/ccifnces/index.php/comments/ el_secado_del_cafe_otra_de_las_claves_para_que_el_ cafe_de_colombia_adquiera/ [Jun. 06, 2012].

Coffee Federation. "Colombian coffee production increases $12 \%$ in January. (Federaciondecafeteros)". Available:https://www.federaciondecafeteros.org/clientes/ es/sala_de_prensa/detalle/produccion_de_cafe_de_ colombia_aumenta_12_en_enero/ [Aug. 20, 2017].

J. Henao Arismendy. Evaluation of the coffee drying process and its relationship with the physical properties, chemical composition and quality in the cup. Medellín: National University of Colombia, 2015.

E. M. Lopez Frontal. Revista Ingenieria e Investigación, 1 (2006).

G. I. Puerta Quintero. Revista Avances Técnicos, 3711 (2006). 


\title{
CFD Validation for the Design Methodology of a Cross-Flow Michell Banki Turbine
}

\author{
Steven Galvis-Holguín*, Mateo Del Gallego-Rico*, Daniel Giraldo-Taborda*, \\ Jorge Andrés Sierra-Del Rio*, Daniel Sanín-Villa*
}

Instituto Tecnológico

Metropolitano, Mecatrónica y

Electromecánica, MATyER-CADD,

Colombia.

E-mail:

stevengalvis221631@correo.itm. edu.co

\section{Introduction}

Small hydroelectric power plants are mainly used in non-interconnected, low densely populated areas where power consumption is low, so the provision of electricity from interconnected systems is not economically viable. As for 2015, around $61 \%$ of the total global renewable energy was produced by hydropower sources. Of this, $4.5 \%$ and $7 \%$ were produced for micro- and small-hydropower, respectively. Hydropower with an installed capacity below $100 \mathrm{~kW}$ are categorized as micro-hydropower. On the contrary, hydropower with a power between $100 \mathrm{~kW}$ and $10 \mathrm{MW}$ are categorized as small-hydropower (Endashaw Tesfaye Woldemariam, Hirpa G. Lemu, 2018). Therefore, the non-interconnected zones, where there is availability of water resources constitute key points to apply cross-flow turbines (CFT). Many system peak-hydropower employ Michell-Banki turbines due to their simple design, low manufacturing cost and wide range of implementation in small plants for operating with hydraulic jumps and low flow rates. However, compared to more advanced and efficient designs such as Pelton and Francis turbines (Dragomirescu, 2016), the Michell-Banki type tends to present lower efficiencies, because there are no design methodologies that contain the new equations found in the literature for the sizing of each one of the elements that make up the turbine, based on site conditions where the turbine will be implemented (Alfonso, Gutiérrez, Tur, \& Banki, 2008), (Energía et al., 2010).

\section{Experimental}

In this study, a methodology for the design of a high efficient Michell-Banki CFT was carried out. Its validation was done by computational fluid dynamics in the CFX module of the commercial program ANSYS-19, using a computer with 16 processing cores and 256 GB of RAM, which reduced computation time considerably.

\section{Results and Discussion}

The design of a CFT was performed with the best parameters found in the literature and through CFD the design of the Michell-Banki turbine was validated. 
Table 1 shows the mesh study carried out for the first simulated model, mesh independence with 10 million elements was achieved.

Table 1. Mesh study

\begin{tabular}{|c|c|c|c|c|}
\hline $\begin{array}{c}\text { Theoretical } \\
\text { torque } \\
\left(\mathrm{N}^{\star} \mathbf{m}\right)\end{array}$ & $\begin{array}{c}\text { Numerical } \\
\text { torque } \\
\left(\mathbf{N}^{*} \mathbf{m}\right)\end{array}$ & $\begin{array}{c}\text { Number } \\
\text { of } \\
\text { elements }\end{array}$ & $\begin{array}{c}\text { Relative } \\
\text { error } \\
(\%)\end{array}$ & $\begin{array}{c}\text { Efficiency } \\
(\%)\end{array}$ \\
\hline 6.43 & 6.12 & 4.1 million & ----- & 95.18 \\
\hline & 5.72 & 4.3 million & 6.53 & 88.95 \\
\hline & & $\begin{array}{c}10.5 \\
\text { million }\end{array}$ & 1.02 & 87.86 \\
\hline
\end{tabular}

The volumetric fraction of water and air (figure 1) and the water velocity (figure 2 ) at the time of passing through the different domains can be evidenced. The expected behaviour for the two previously mentioned characteristics is observed; Nozzle is completely filled with water and runner present cross-flow that go through its middle and allows double exploitation of the fluid energy that distinguishes CFT.

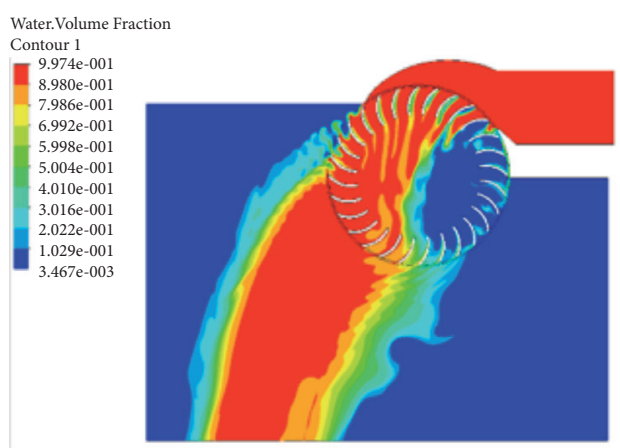

Figure 1. Water volumetric fraction

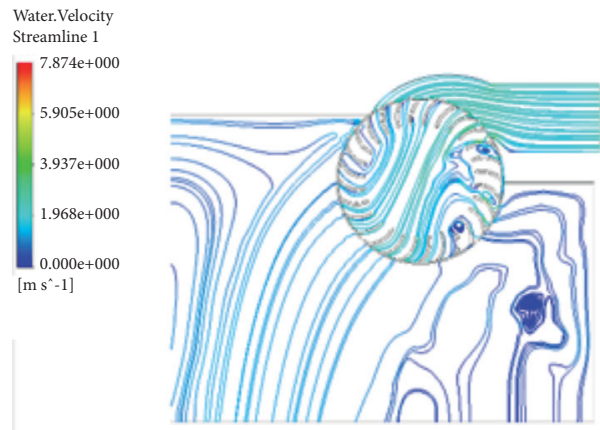

\section{Conclusions}

- A CFT design method that allows - based on the site's data (head and available water flow rate)to significantly shorten the time required in this stage and to achieve a set where all its elements are designed in the best way according to the investigations available so far was developed.

- The methodology used for the CFT design may reach efficiencies of up to $87 \%$. This is satisfactory for solving the shortage of complete design methods for the sizing of different components of the Michell-Banki type CFT (nozzle, runner and housing), depending on the installation's site conditions.

- The exploitation of small sources of hydroelectric energy requires using small turbines that combine efficiency and economy. In such cases, CFT represents an excellent option because of its great advantages, especially its simplicity and good performance in variable flow rate conditions.

\section{References}

C. Alfonso, P. Gutiérrez, D. Tur and M. Banki. Avances en Recursos Hidraúlicos, 1733 (2008).

A. Dragomirescu, "Numerical investigation of the flow in a modified Banki turbine with nozzle foreseen with guide vanes," 2016 International Conference and Exposition on Electrical and Power Engineering (EPE), Iasi, 2016, pp. 874-879.

E. Tesfaye Woldemariam , H. G. Lemu, and G. G. Wang. Energies, 11248 (2018).

Consorcio Energético Corpoema. (Dec. 30, 2010). Formulación de un plan de desarrollo para las fuentes no convencionales de energía en colombia (PDFNCE). (Vol I) [Online] Available: https://bdigital.upme.gov.co/bitstream/001/994/1/Vol\%201\%20Plan\%20Desarrollo.pdf

Figure 2. Water velocity 


\title{
Aerodynamic Performance Evaluation of a NACA 4415 Profile by means of Computational Fluid Dynamics
}

\author{
Juan Diego Betancur ${ }^{\star}$, Juan Gonzalo Ardila*
}

Instituto Tecnológico

Metropolitano, Medellín, Colombia E-mail:

juanbetancur134613@correo.itm. edu.co

\section{Introduction}

The wind is a free and clean source of renewable energy. The kinetic energy of the wind can be exploited by wind turbines. For the design of its rotors, the behaviour of the forces and the moments on each blade must be predicted according to the chosen aerodynamic profile. The characterization of the performance of aerodynamic profiles involves the construction of their power curve. Computational Fluid Dynamics (CFD) is a promising method in this application due to its low cost and accuracy. As an example, Shukla and Kaviti have shown, by means of $2 \mathrm{D}$ simulations, that the torque generated by a blade constructed with a NACA 0021 profile is greater than the one generated by a NACA 0018 , both profiles with an angle of attack of $16^{\circ}$ [1]. Yavuz and others developed a study on two NACA profiles (4412 and 6411), in which they looked for the angle of attack where the ratio between the coefficient of sustentation $\left(C_{L}\right)$ and the drag coefficient $\left(\mathrm{C}_{\mathrm{D}}\right)$ was maximum, as well as points where $\mathrm{C}_{\mathrm{L}}$ achieved its highest values, finding that the optimal angles of attack were between $10^{\circ}$ and $24^{\circ}$ for both profiles [2]. Goundar, on the other hand, used an S1210 aero profile and showed that increasing the curvature by $20 \%$ a new aerofoil called HF-Sx was obtained and showed a significant improvement in $\mathrm{C}_{\mathrm{L}}$ at different angles of attack [3]. Other research have shown, through simulations, improvements in $C_{L}$ vs $C_{D}$, implemented modifications in the geometries of the airfoil profiles NACA 0012, 0015, 0018 and $0021[1,4]$, or NACA 4415, S809 and NASA 1s421e [5]. The curves of the coefficients against the angle of attack are constructed to choose the best profile to design a turbine.

The most common turbulence model for $2 \mathrm{D}$ investigations of this type is the k-w SsT used by $[4,6-8]$ validated their computational models with experimental results. Given the importance that $\mathrm{CFD}$ has acquired in obtaining $\mathrm{C}_{\mathrm{L}}$ and $C_{D}$ curves of different profiles, the main objective of this study is to create coefficient curves by means of $2 \mathrm{D}$ simulations of the NACA profile 4415 with the turbulence model k- $\omega$ SST, and observe the behaviour of the parameter $y+$, in order to validate a model that can be used to simulate other types of profiles for which no experimental information is available. 


\section{Experimental}

The present work reports the simulations developed in a T7600 workstation that has two $2.90 \mathrm{GHz}$ processors, with 64 GB of RAM. The program used was ANSYs V18.1 and the CFD solver used was Fluent. To validate the simulation results of the NACA 4415 profile, the experimental results reported by Hoffmann et al., were used [9]. The simulation starts with the development of the profile, through the points taken from the open Xfoil database. This is exported to SolidWorks and the profile is generated in 2D. This is then exported in igs format to the DesignModeler and a geometry is created as shown in Figure 1(a), which consists of a semicircle of radius 12.5 times the length of the chord (L) centred on $40 \%$ of the aero profile chord and a rectangle of $20 \mathrm{~L}$ by $25 \mathrm{~L}$ that is attached to the semicircle generated previously. Two vertical lines pass through the centre of the semicircle and along the discharge edge of the profile, while a horizontal line passes over the rope dividing the profile into two. This process is carried out in order to generate a mesh of acceptable quality.
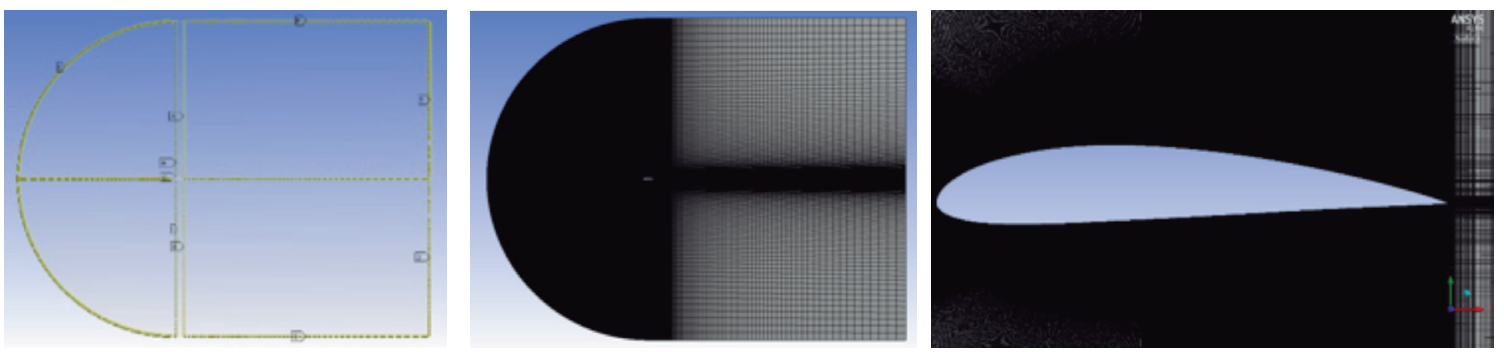

Figure 1. (a) Geometry with edge sizing. (b) Mesh generated with profile in the centre (c) Enlargement of the mesh

Meshing is done in the module meshing for 2D elements creating several edge sizing as shown in Figure $1(\mathrm{~b})$ and (c). Depending on the place of sizing, certain characteristics are given to consolidate the inflation effect, densify the areas near the profile and obtain a $\mathrm{y}^{+}<1$, which is the dimensionless distance of the node closest to the profile, and must be $0.0001 \mathrm{~mm}$ for a Reynolds of 1'000,000. Finally, after making an independence study in which the variation of the lift force was observed as the mesh was densified, the mesh shown in Figure 1(b) was chosen with a total of 2'352,000 elements. This mesh has a maximum obliquity of 0.77 and a minimum orthogonality of 0.15 , fulfilling the criteria of metrics acceptability. In Fluent, the stationary simulation based on pressure and velocity was configurated. For the configuration of the solver the following values for Reynolds of 1'000,000 were used: Input speed $122 \mathrm{~m} / \mathrm{s}$ with components of speed in X and $\mathrm{Y}$ to vary the angle of entry of the velocity from $-6^{\circ}$ to $10^{\circ}$, air was used as fluid with ideal gas properties, the turbulent intensity was $1 \%$, the lift and drag forces were monitored, and was initialized in a hybrid manner. For the solution method, second order equations were chosen because of their degree of precision.

\section{Results and Discussion}

Once the lift and drag forces have been calculated, the aerodynamic coefficients are determined in order to compare the simulation results with the experimental ones. The preliminary results were purchased with the experimental tables B8 and B2 of Hoffmann and others [9]. Both tables show the results for profile NACA 4415 with Reynolds of 1'000,000, with the only difference being that the profile of the table B8 has a size of particle that adds friction to the surface Figure 2(a) shows three curves that correspond to $C_{L}$ against the angle of attack (AoA) of the NACA profile 4415. Two curves belong to experimental results and the third corresponds to simulation results. It can be seen that the curves obtained from experimental results show a similar behaviour, while the simulation graph presents an acceptable trend between $-3^{\circ}$ and $6^{\circ}$, but at the extremes there is no good adjustment.

Figure 2(b) presents three curves that correspond to $\mathrm{CD}$ against AoA. It can be seen that the simulation curve starts at $-6^{\circ}$ near the two experimental curves and moves away until at $2^{\circ}$ it achieves an important approach, but more later, with the $8^{\circ}$ 
inclination it moves away from the experimental values again. In both figures it is evident that the more inclined the profile in relation to the fluid inlet, the simulation results move away from the experimental ones, due to the fact that at these angles there is a greater detachment of the boundary layer and the turbulence model. When this phenomenon is not fully captured, some forces generated around the profile are not captured adequately for the calculation carried out by the program.
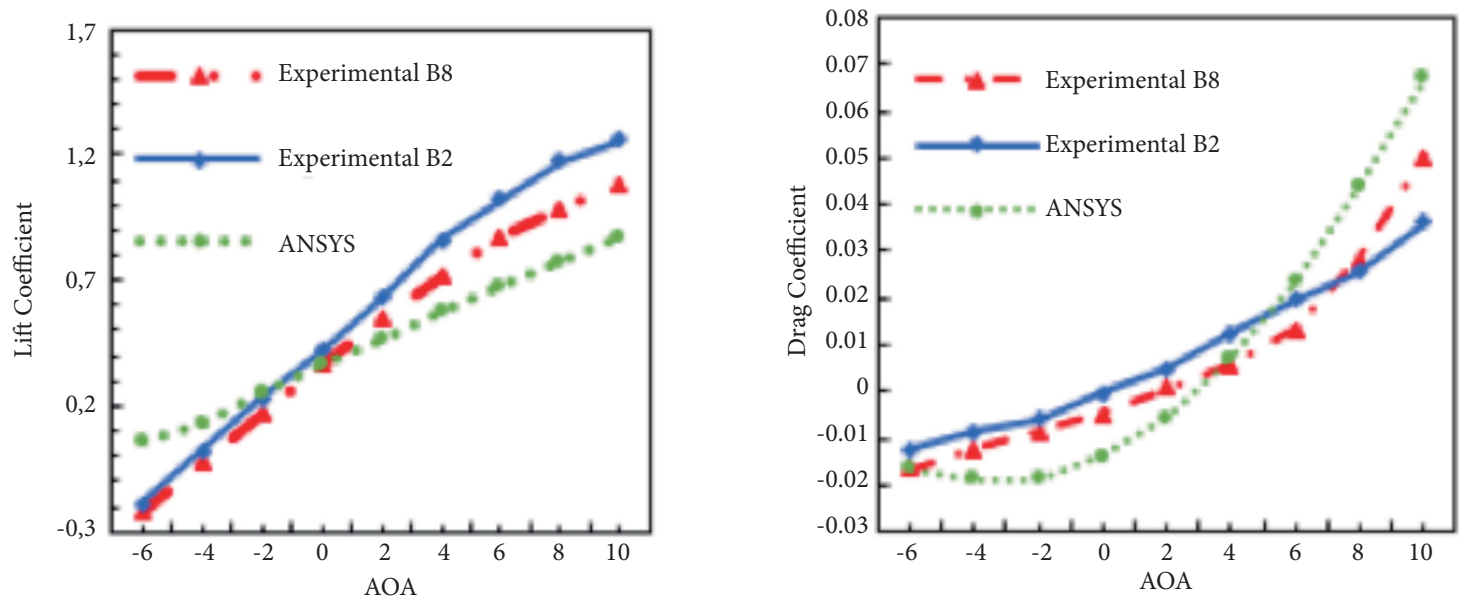

Figure 2. Comparison of experimental and simulation coefficients for a NACA profile 4415. a) Lift. b) Drag

\section{Conclusions}

The detachment of the boundary layer is a phenomenon that greatly affects the calculation of lift and drag forces. For this reason, robust turbulence models must be chosen and adequate meshes must be developed. CFD is a very useful tool to obtain results that are usually found in experimental tests in a cheaper and faster way. It is possible to create lift and drag coefficient curves against the angle of attack of aerodynamic profiles by means of CFD simulations and thus evaluate their behaviour for the design of wind turbine blades or wind turbines.

\section{References}

V. Shukla and A. K. Kaviti, Energy, 126766 (2017).

T. Yavuz, E. Koç, B. Kılkış, Ö. Erol, C. Balas, T. Aydemir. Renew. Energy, 74414 (2015).

J. N. Goundar, M. R. Ahmed, and Y. H. Lee, Renew. Energy, 42173 (2012).

M. F. Ismail and K. Vijayaraghavan, Energy, 8020 (2015).

R. Lanzafame, S. Mauro, and M. Messina, Renew. Energy, 5231 (2013).

L. Wang, R. Quant, and A. Kolios, J. Wind Eng. Ind. Aerodyn., 15811 (2016).

R. Lanzafame, S. Mauro, and M. Messina, Renew. Energy, 5231 (2013).

C. C. Huang, C. J. Bai, Y. C. Shiah, and Y. J. Chen, Energy, 1151156 (2016)

M. J. Hoffmann, R. Reuss Ramsay, and G. M. Gregorek,. Effects of grit roughness and pitch oscillations on the NACA 4415 airfoil. Golden, Colorado: NREL, 1996. 


\title{
Study in Thermal Photovoltaic Panels Cooled by Heat Sinks modelled by Computational Fluid Dynamics
}

\author{
Yustin Roman ${ }^{\star}$, Jorge Sierra ${ }^{\star}$, Diego Hincapié ${ }^{\star}$
}

Instituto Tecnológico Metropolitano, Medellín, Antioquia, Colombia E-mail:

yustinroman188676@correo.itm. edu.co

\section{Introduction}

Solar panels, technically called photovoltaic modules, work through the photoelectric effect produced when light hits them. Environment protection is a commitment for governments, people and industries. Today we see a great growth in the production of cheaper solar panels and in the implementation of large solar plants connected to the electricity grid. For this reason, improvements in efficiency are currently a study of great importance.

Photovoltaic panels can reach efficiencies between 14 and $17 \%$ depending on the materials they are made of. Experimental and numerical studies have shown that one of the problems for the use of photovoltaic cells is the effect of temperature. When the solar panel heats up, the conversion efficiency from light to electrical energy decreases.

In this study, different geometries with different dissipater measures such as height and position will be considered. The solar cells will be fixed to the upper wall with a thickness of $0.0003 \mathrm{~m}$. In addition, the geometries of the heat sinks of $25 \mathrm{~mm}$ and $50 \mathrm{~mm}$ of height and with thickness of $1 \mathrm{~mm}$ will be presented.

\section{Experimental}

A study was carried out using computational fluid dynamics (CFD) with ANSYs 18.2 software. In order to analyse the behaviour of the temperature in the solar cell and how it affects its energy generation efficiency, the heat transfer between a solar panel with a heat sink was modelled.

After identifying the problem and analysing its viability, the convergence and stability of the result was checked modelling the geometry of a photovoltaic cell, with its respective heat sinks, using the Design Modeler module of the ansys 18.2 software. A study of the mesh geometry was made using the finite element method for the development of partial differential equations that provide a solution to the problem. 
For validity, the proposed model compared the temperatures of cells obtained in the simulation with their mathematical model. The following table presents these values.

Table 1. Theoretical and experimental temperature

\begin{tabular}{|c|c|c|}
\hline $\begin{array}{c}\text { Theoretical } \\
\text { temperature (K) }\end{array}$ & $\begin{array}{c}\text { Fluent } \\
\text { temperature (K) }\end{array}$ & Error (\%) \\
\hline 359.78 & 336.95 & 6.8 \\
\hline 357.22 & 390.1 & 8.4 \\
\hline 357.22 & 363.36 & 1.7 \\
\hline 352.83 & 353.5 & 0.2 \\
\hline 346.22 & 341.06 & 1.5 \\
\hline 338.69 & 331.35 & 2.2 \\
\hline 357.22 & 350.34 & 2 \\
\hline 352.83 & 337.57 & 4.5 \\
\hline 346.22 & 325.12 & 6.5 \\
\hline 338.69 & 317.1 & 6.8 \\
\hline
\end{tabular}

Figure 1 shows that a higher heat transfer area and an increased number of heat skinks per cell improve the panel's temperature. The lowest temperature of $313.87 \mathrm{~K}$ was obtained with the $50 \mathrm{~mm}$ dissipater and 8 dissipaters per cell. The effect of the lower regime temperature for the solar panel represents an increase in system efficiency. Figure 2 shows an increase in efficiency of about $2 \%$.

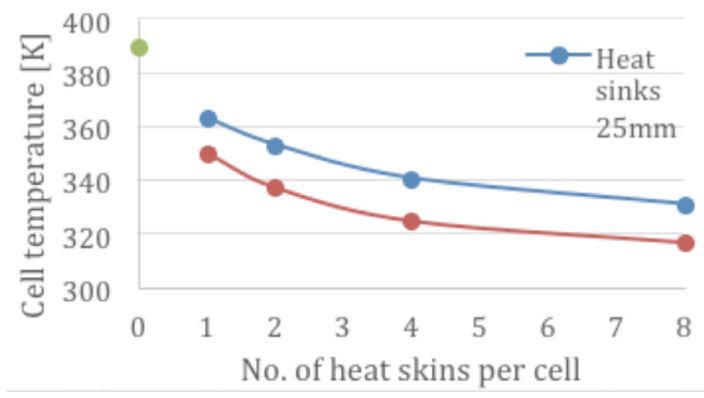

Figure 1. Cell temperature of heat sinks of $50 \mathrm{~mm}$ and $25 \mathrm{~mm}$

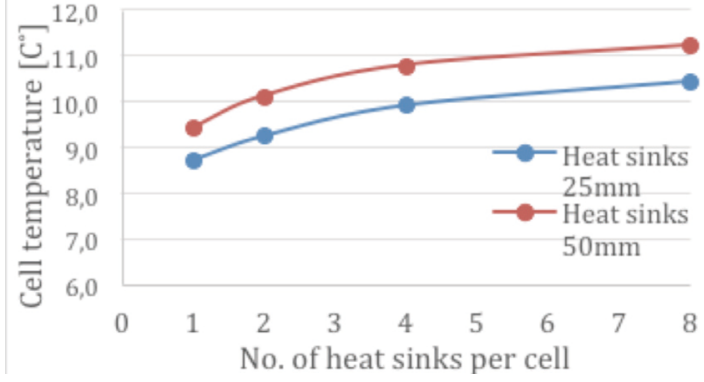

Figure 2. Difference of cell efficiency

\section{Conclusions}

It is observed that increasing the heat sink area improves the temperature of the panel, which increases as more heat sinks per cell are used. The lowest temperature was obtained with $50 \mathrm{~mm}$ sinks and 8 heat sinks per cell.

The simulation values present a good approximation to the mathematical model with maximum errors of $8 \%$. This represents a reliable validation method that may be replicated in other cases.

\section{Acknowledgements}

Acknowledgments to Professor MsC. Jorge Sierra del Rio and Professor MsC. Diego Andrés Hincapié Zuluaga for their guidance and support in advanced computing and digital design.

\section{References}

C. G. Popovici, S. V. Hudişteanu, T. D. Mateescu, and N.-C. Cherecheş, Energy Procedia, 85425 (2016).

S. Agrawal, G. N. Tiwari. Sol. Energy, 85356 (2011).

S. Agrawal, G. N. Tiwari. Sol. Energy, 862826 (2012). 


\title{
Central Location Optimal Distributed Generation to Minimize Effects of Harmonics in Power Distribution Networks: Dominican Republic Case Study
}

\author{
Manuel A. Landron*, Richard Gil Herrera*
}

Univesidad Americana de Europa (unade), Cancún, Mexico

E-mail:

motato117@gmail.com

\section{Introduction}

Distributed Generation (GD) consists of the support to electricity demand through a localized system, which also allows generating alternatives using renewable small and medium-scale energies. (2) At present, a large amount of research focuses on the benefits of systems used in distributed generation and the promotion of renewable energy sources. The use of these systems leads to new technical and operational problems in the network management, such as the presence of harmonics, hollow intention, transient stability problems, reactive power control and (2) technological limitations in energy storage. In addition, the field experiences other problems such as difficulties in planning and a shortage of incentives for network regulation.

To improve network operating conditions, the creation of restrictions, limitations and infrastructure improvements where the distributed generation takes place is needed. This research identifies network points where DG technologies may be restricted or encouraged, taking into account operational aspects and the decrease in the progression of harmonic distortions [1].

At present, harmonic distortions are a phenomenon still to be assessed. Nevertheless, proposals for power generation since they increased (smelters, power electronics, household electronic systems, nonlinear circuits, variable speed systems in the industry, etc.) emerged and have made the field boom. Interconnection regulation bars and estimates should be studied in terms of negative factors that increase with these inserts, trying to maintain healthier architectures and efficient networks.

In the Dominican Republic, regulations that govern the electricity market do not take into account network optimization, which results in a disorganized network growth by generating an inefficient architecture with high rates of energy loss and poor quality. Basically, the investor trying to insert projects into a bar will have a factor that will affect the viability of the project. There are other factors affecting energy quality, but they have little harmonic analysis information network effects of medium and high voltage. 


\section{Experimental}

For this investigation, an isolated network of the Dominican Republic known as the network Samana peninsula, consisting of 10 bars was assessed. Simulations of real network conditions were performed selecting the network's most critical condition in longer time. The simulations were performed using DIgSILENT 15.1 software (4), which is widely used in the power industry (6), and the values such as voltages, currents, harmonic distortion, reactive power and power factor of the network were recorded. Next, second parameters that define the generating units and loads connected to the bars such as power, voltages, percentages of ammonium injection, currents, production cost functions and limit powers were recorded.

From these data, a penalty table where production costs increase was constructed, it backs on the marginal cost of the bar and its percentage of harmonic distortion, which will vary for each bar.

DG technologies are evaluated and their characteristics defined: photovoltaic plants, wind power plants, gas turbines and diesel plants. The production costs and their contribution to network harmonics are estimated. Then, the software is run considering the above conditions, and the values of marginal cost of generation, voltages, harmonic distortion of each bar are recorded. For each iteration, the central lowest marginal cost and the bar with the lowest rate penalty and inserted into said bar are selected. A software run is then performed. For each bar it presents new harmonic distortion values and marginal costs. The next unit of lowest marginal cost is selected and the bar with less penalty is studied.

The procedure is iteratively performed until the marginal network cost is less than the cost of the core available. When the condition is met, the act of inserting a unit increases the marginal cost inefficiency, generates a condition of the network, and the iterative process is finished.

\section{Results and Discussion}

After following the procedure described above values increased exponentially with less harmonics recorded, resulting in a network with strong or better architecture. In fact, this decreases the likelihood of investing less resources to improve the network's quality and to avoid the use of expensive equipment such as: harmonic filters, relocation of transformers, filter capacitors, changes voltage transmission lines, increased section conductors and equivalents.

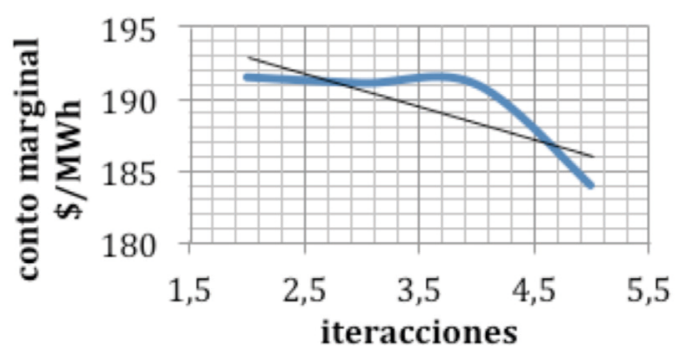

Figure 1. Changes in marginal cost per iteration

Harmonics parameters are taken from the norm IEEE 519-1992.

As shown in Figure 2, the harmonic effects are still within permissible values according to the IEEE 519-1992 standard. A bad location of these plants represents increased harmonic distortion values in the bar, which decreases the quality of energy served on the net.

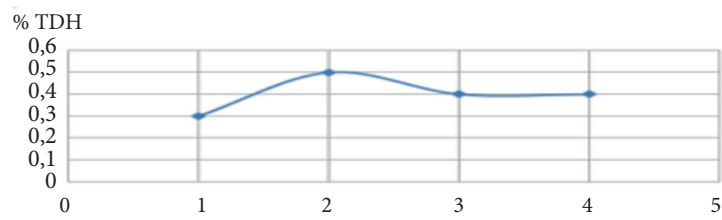

Figure 2. Changes in harmonic distortion iterations rod 5

\section{Conclusion}

The central location of distributed generation in the Dominican Republic is of operational and strategic interest. This work represents an experimental and practical approach (for a case study) that contributes to build a more efficient and effective network, from both the system operator and network users point of view.

\section{References}

T. Ackermann, G. L. Andersson and Soder. Electric Power Systems Research, 57195 (2001).

L. Grisales, B. Restrepo, F. E. Jaramillo. Science and engineering neogranadina, 27157 (2017).

J. Lopez, A. Padilha. L Gallego, Engineering and Science, 5 9 (2009). 


\title{
Optimal Equalization of Distributed Energy Storage Systems in a Microgrid
}

\author{
Nelson L. Díaz ${ }^{\star}$ Adriana C. Luna ${ }^{\star *}$
}

Universidad Distrital Francisco José de Caldas, Bogotá, Colombia

** Universidad de los Andes, Bogotá, Colombia

E-mail:

nldiaza@udistrital.edu.co

\section{Introduction}

The development of variable renewable energy sources (VRES) such as photovoltaic (PV) and wind turbine (WT) has allowed the diversification of the electrical grid. However, the uncertain nature of the primary energy resources implies additional technical challenges for ensuring a proper integration and an efficient use of the available energy [1]. For that reason, energy storage systems (ESS) based on batteries commonly accompany the integration of VRES in order to level their variability and avoid problems related with power injection to the grid during periods of high generation, which assures an energy reserve during periods of low generation [2]. This cluster of ESS and VRES is commonly denoted as an active generator (AG), it can provide some degree of dispatchability to the VRES, enabling its participation in the management and regulation of the power grid [3].

In this scenario, a power grid may integrate distributed AG with different capacities and VRES, which means distributed ess with different capacities and cycling, since each Ess is fitted and managed in accordance to its corresponding VRES. As a consequence, the available energy and distributed storage resource may be sub-optimally used due to the disaggregated operation of the distributed resources. This work proposes a coordinated operation of the distributed Ess which are part of AG's, to optimize and unify their charging profiles. In this way, it is possible to avoid uneven degradation of the distributed storage units and operate with them as aggregated Ess [4]. A grid-connected microgrid environment has been used in order to test the proposed strategy.

\section{Experimental}

A grid-connected hybrid microgrid has been considered as case study, as shown in Figure 1. The microgrid is composed by two PV and WT based active generators, a residential load and the main grid. Figure 2 shows the generation and consumption profiles for a time horizon of 24 hours. The operation of the microgrid has been optimized in order to minimize the energy consumption from the main grid and maximize the use of the primary energy resource. The operation 
of the system has been optimized by means of linear programming modelling by using an algebraic modelling language which assumes a forecasted profile of consumption and generation.

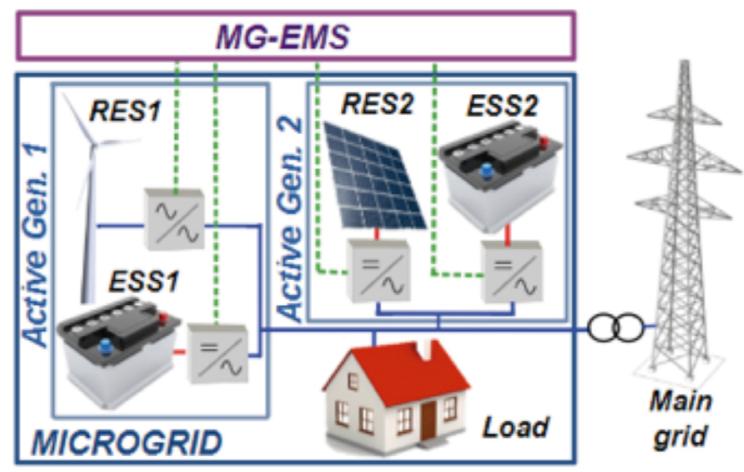

Figure 1. Microgrid configuration

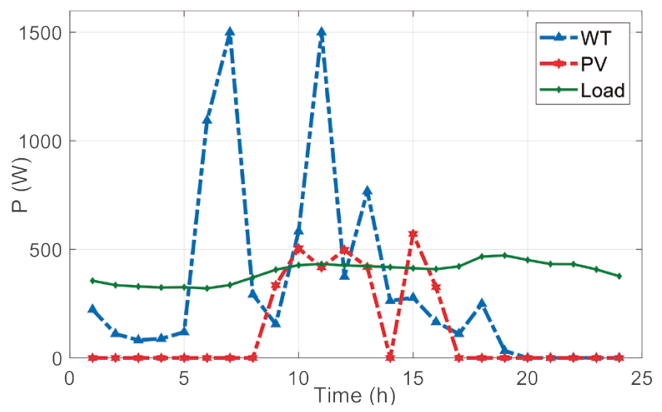

Figure 2. Generation and consumption profiles

\section{Results and Discussion}

Two cases have been compared in order to test the performance of the microgrid. The first one considers the basic optimization objectives described above, whereas the second case includes the state of charge (SoC) equalization in order to unify the charging profiles of the distributed Ess within the optimization model. By comparing the performance in both cases, the main optimization objectives were achieved with similar results. This means that no energy is used from the main grid and all the energy from vres is used. Nevertheless, the charging profiles of the Esss are different, as shown in
Figures 3 and 4, for the non-equalized and equalized case respectively. It is possible to see that the minimum SoC, which indicate the amount of energy stored in the ESS is larger and a smoother profile is achieved for both Ess once the equalization is performed. Then, the number of micro cycles in each unit is reduced, which moderate their degradation.

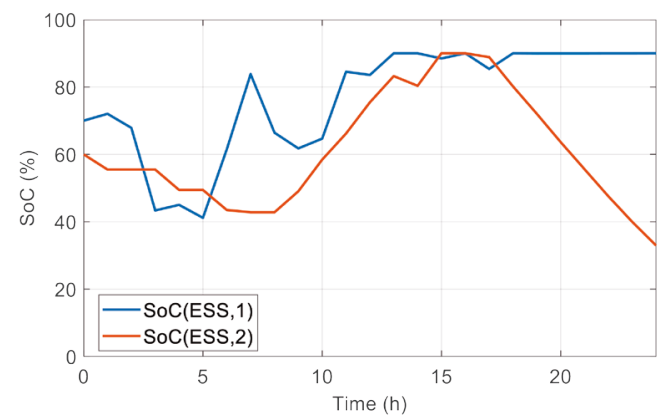

Figure 3. SoC profiles without equalization

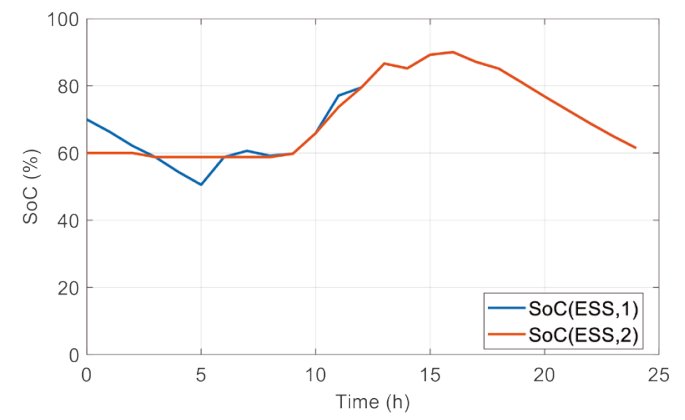

Figure 4. SoC profiles with equalization

The performance of the proposed optimization was tested several days with different generation profiles. In this case, eight days in a period of a year were selected randomly, in order to compare the minimum levels of SoC obtained without and with the equalization. Figure 5 shows a histogram for the comparison where it is possible to see that the number of cases in which the SoC reaches levels of operation smaller than $50 \%$ is larger when the equalization is not performed. Therefore, the degradation of the Ess will be faster without the equalization. 


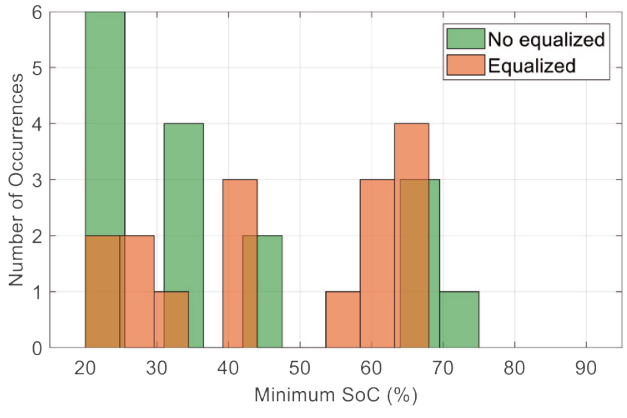

Figure 5. Histogram of minimum SoC cases

\section{Conclusions}

An equalization of distributed Ess has been proposed as part of an optimized management of a grid-connected microgrid composed by active generators. The equalization may reduce the overall degradation of the distributed Ess based on batteries, without compromising the main optimization objectives. Additionally, the equalization of the Ess allows to unify the charging profile, then the distributed ess can be managed as an aggregated Ess which could simplify the management of the system.

\section{Acknowledgements}

This Research has been co-financed by The Centre for Research and Scientific Development of the Universidad Distrital Francisco José de Caldas (CIDC) (Project number: 2-7-563-17), and Colciencias (Project number: C145I005000000885-5, call 784-2017).

\section{References}

Y. Li et al., "Study on voltage control in distribution network with renewable energy integration," in 2017 IEEE Conference on Energy Internet and Energy System Integration (EI2), Beijing, pp. 1-5, (2017).

F. Marra and G. Yang, "Chapter 10 - decentralized energy storage in residential feeders with photovoltaics," in Energy Storage for Smart Grids, P. D. Lu, Ed. Boston: Academic Press, 2015, pp. 277-294.

E. Limouchi, S. A. Taher, and B. Ganji, "Active generators power dispatching control in smart grid," in 2016 21st Conference on Electrical Power Distribution Networks Conference (EPDC), pp. 26-32, (2016).

N. L. Diaz Aldana, "Coordinated Control and Management of Distributed battery-based energy Storage Systems for Islanded Microgrids". PhD Thesis, Aalborg Universitet, Denmark, 2016. 


\title{
Reference Model for Smart Technologies Management based on National Science and Innovation Policy for Sustainable Development - Colombia, Agenda 2030
}

\author{
Gina Maestre-Góngora*, Ramón F. Colmenares-Quintero*
}

Universidad Cooperativa de Colombia, Colombia

E-mail:

gina.maestre@campusucc.edu.co

\section{Introduction}

Smart Technologies (sT) are defined as a generalization of the concept of intelligent structures. ST comprises a physical system equipped with sensors, pre-programmed controls for users with specific requirements and needs, which allow the system to adapt to extreme or particular conditions. The concept of ST requires a combination of the physical system, embedded sensors, control devices, software-integrated electronic devices that provide the "intelligence" of the system [1]. These technologies include hardware, software and communications systems that are capable of automatically adapting and modifying their behaviour (parameters), generating information and knowledge to support decision-making. Currently, the new policy of the Colombian Government is guiding the path of Science and Innovation to advance decisively towards the achievement of the 17 Sustainable Development Goals (sDG). This new policy, which outlines the Science, Technology and Innovation (STI) path for the implementation of the 2030 agenda proposed by the SDG, establishes five principles: directionality, participation, learning and experimentation, interdisciplinary nature, and anticipation of results and effects, as channels for change for social and technological transformation [2]. The information technologies (IT), in particular smart technologies, become a catalyst for these initiatives supporting the principles of the 2030 agenda; but high intelligence and problem-solving capacity cannot be ensured unless IT is integrated into a broad architecture of coordination between physical, institutional and digital spaces in the social environment where the needs are met. [3]

This research aims to identify the role of smart technologies through a reference model based on the five principles of the Colombian 2030 agenda, in order to support the development of initiatives aimed at Goal 7: Affordable and clean energy, and Goal 11: sustainable cities and communities, creating an environment for information exchange, collaboration, interoperability for all inhabitants through smart IT, improving the possibilities of access to renewables and alternatives, and create conditions where they can be better used. 


\section{Reference Model}

The model is proposed to facilitate the execution of a strategic direction through projects supported in infrastructures, services, data, information and processes for implementing the sTI policy in Colombia, articulated with objectives of sustainable development (especially, Goal 7 11) in the context of rural areas with energy access needs and possibilities of implementation of renewable or alternative energies (Figure 1).

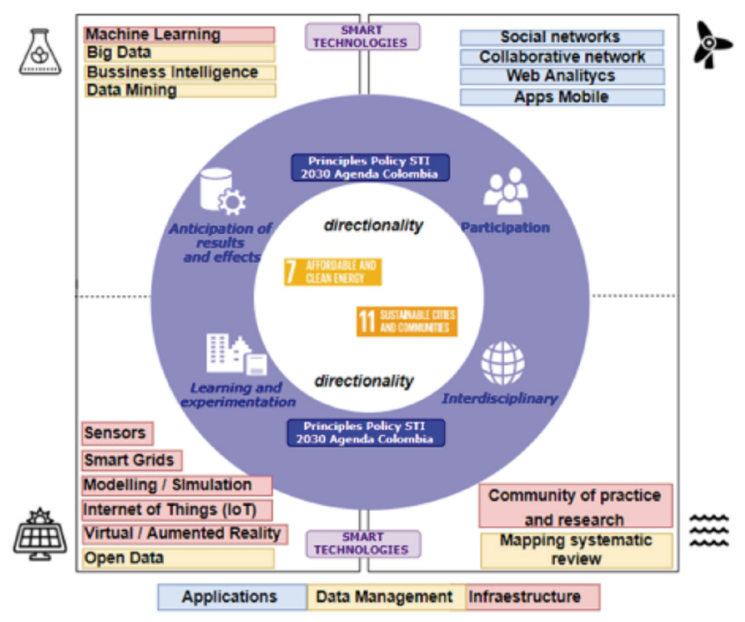

Figure 1. Reference model for smart technology applied in energy projects

1. Directionality: It refers to a collective process in which the current situation and the sustainability possibilities of the projects are considered in order to guide actions towards necessary and desirable changes in the technological context for the development of the projects. For this purpose, the following is required:

- Data collection and analysis (open data, national and local statistics) for the selection of energy technology (e.g. hydrokinetics, wind, solar, biomass)

- Identification of technological resources in the area (e.g. connectivity, access to data networks, telephony, community internet access centres)

- Digital literacy baseline of the population receiving the energy projects
- Identification of community and social leaders

- Awareness of the use and appropriation of technologies that will support energy projects

2. Participation: It refers to the active involvement and dialogue between the various stakeholders for the generation, use and access to knowledge and innovation that make a contribution to sustainable development through collaborative or innovative technologies. Here, technologies such as: social networks, collaboration networks, network analytics, and mobile applications can play an important role as communication facilitators between all actors involved.

3. Interdisciplinary: Various disciplines and knowledge's collaboration to conceive and search for solutions, exploring different alternatives that contribute to the technical, social, economic and environmental sustainability of the energy project. Communities of practice and research supported by information technology share the same interest in deepening their knowledge and experience from several areas of knowledge, such as engineering, social sciences, economics and the environment, which can contribute to the initiative.

4. Learning and experimentation: It allows to create spaces and actions supported by smart technologies that generate processes of reflection, transmission, acquisition of knowledge and experience, in order to reorientate the directions of change and adjust the initiative or future projects. Technologies such as augmented reality, virtual reality, modelling and simulation, and smart grids combined with information obtained from sensors, IoT and open data allow the substitution of real situations with ones artificially created. This allows identification of factors, variables and process conditions that may influence the resolution of situations that affect the project.

5. Anticipation of results and effects: It refers to the set of predictive and prescriptive techniques used to analyse and transform large volumes of data into information to improve decision-making; providing information to analyse, infer or identify behavioural trends based on real-time system data through the use of big data, machine learning, business intelligence and data mining. 


\section{Conclusions}

Smart technologies are becoming a fundamental element in advancing sustainable development objectives, but it is important to highlight that it is not enough to invest in the provision of infrastructure only but also in the provision of innovative services that support a strategy to promote dynamic, flexible and collaborative projects sustainable in the mid- and long-term.

\section{Acknowledgements}

The authors acknowledge the Universidad Cooperativa de Colombia for funding the research project "Management Framework for Smart Technologies for Research Projects: Case
Study Engineering Studio UCC" with ID 2211, and "Identification of Knowledge Gaps in the Academia and Capacity Building for Aquatic Renewable Energy in Colombia" with id 2210 funded by Newton Fund. Gina Maestre acknowledges Colciencias for the scholarship for doctoral studies (2013-2018), to obtain the PhD degree in Systems Engineering.

\section{References}

J. Holnicki-Szulc. Smart technologies for safety engineering. West Sussex, England: John Wiley \& Sons, 2008.

Colciencias (Jul. 2018). Libro Verde 2030 Política nacional de ciencia e innovación para el desarrollo sostenible. [Online] Available: http://libroverde2030.gov.co/wp-content/uploads/2018/07/LibroVerde2030-5Julio-web.pdf

G. Maestre, W. Nieto. Journal of Technology Management \& Innovation, 10201 (2015). 


\title{
Termohaline Characterization of the Gulf of Urabá Central Region, from the Atrato River Discharge
}

\author{
Juan C. Guevara Aguirre*, Luis A. Velásquez Ortega*, Vladimir G. Toro*, \\ Reginaldo Durazo Arvizu**
}

Universidad de Antioquia, sede Ciencias del Mar, Turbo, Colombia

** Universidad Autónoma de Baja California, Baja California, Mexico E-mail:

juancarlosguevaraaguirre@gmail. com

\section{Introduction}

The water profile characteristics of the net circulation within the estuaries are modulated mainly by variables such as river discharge, tidal wave (height and frequency) and water stratification [1]. In regions with micro-tidal conditions, the interaction between the discharge of rivers and ocean waters mainly defines the characteristics of the water profile within the estuary. In general, the stratification of the profile is modulated by thermohaline processes (temperature and salinity of the water layer). These processes define whether an estuary is partially or completely mixed. This work proposes to use data measured in situ with a СТD (Conductivity, Temperature, Depth) in order to characterize the thermohaline properties of the Gulf of Urabá central region, where the largest Atrato River discharge occurs. Our work hypothesis is based on the fact that the discharge of the rivers (mainly the Atrato's) within the Gulf of Urabá, modulates the thermohaline characteristics of the water profile, causing a highly stratified estuary to the Gulf's interior.

\section{Experimental}

In this work, two oceanographic campaigns were carried out to collect data on salinity, temperature and density. The first campaign was held on June 23, 2017, in a transect that goes from the area known as Punta Las Vacas, in a north-western direction, to one of the mouths of the Atrato River. Five east-west-east tours with a total of 80 sets of CTD in 12 hours were conducted. The second campaign was held on July 13, 2017, for which six longitudinal transects were carried out.

\section{Results and Discussion}

\section{First campaign}

The salinity data for the central zone of the Gulf of Urabá (figure 1) show a layer of $\sim 1.5 \mathrm{~m}$, with salinity between 0 and 19 UPs. From $1.5 \mathrm{~m}$ to $3 \mathrm{~m}$, the saline values are in the 20 to 25 ups ranges. It ends with a deep layer of salinity values that increase 


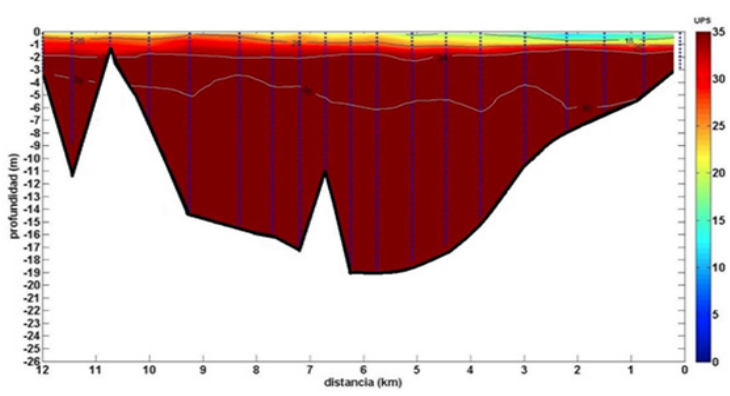

Figure 1. Contour plot of the salinity (UPS) in campaign 1. Minimum value 0 UPS until reaching 35 UPs up to the maximum. The depth is measured in meters and the horizontal range in kilometers.

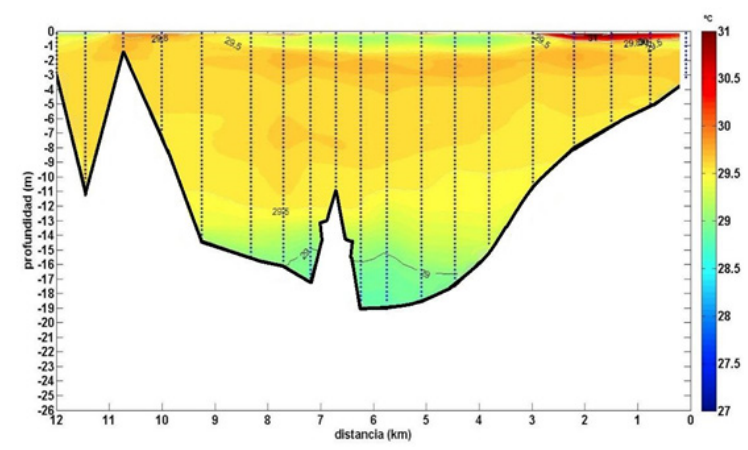

Figure 2. Contour plot of the temperature (Celsius degrees) in campaign 1 . The minimum value $27^{\circ} \mathrm{C}$ (blue) until reaching $31^{\circ} \mathrm{C}$ to the maximum (red). The depth is measured in meters and the horizontal range in kilometers.

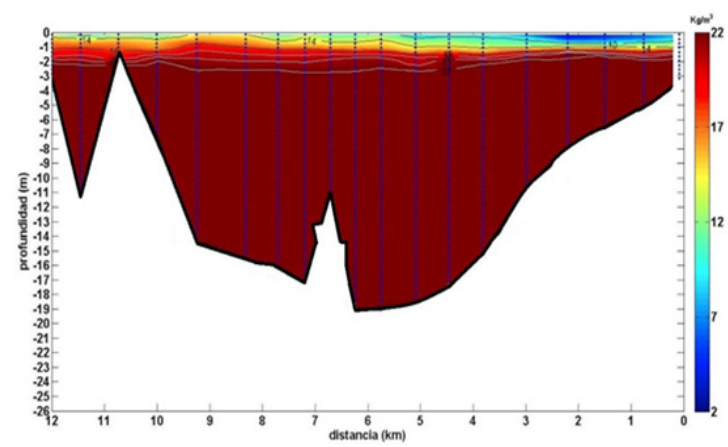

Figure 3. Contour plot of the density $\left(\mathrm{kg} / \mathrm{m}^{3}\right)$ in campaign 1 . The results were graphed for density anomaly (density-1000 kg/ $\mathrm{m}^{3}$ ). Minimum value $1002 \mathrm{~kg} / \mathrm{m}^{3}$ (blue) until reacing 1022 to the maximum $\mathrm{kg} / \mathrm{m}^{3}$ (red). The depth is measured in meters and the horizontal range in $\mathrm{km}$. up to 36 UPs. Regarding temperature, values in the surface presents average values of $29^{\circ} \mathrm{C}$. There is a mass of water with average values of $29.5^{\circ} \mathrm{C}$, up to approximately $13 \mathrm{~m}$ deep. Afterwards the values decrease to $28.5^{\circ} \mathrm{C}$ in the deepest layer. A surface water mass of $1.5 \mathrm{~m}$ depth and length close to $3 \mathrm{~km}$, temperature of approximately $31{ }^{\circ} \mathrm{C}$ is identified (figure 2). The density data (density anomaly, density- $1000 \mathrm{~kg} / \mathrm{m} 3$ ), have values between 1002 and $1012 \mathrm{~kg} / \mathrm{m}^{3}$, in the surface layer of $\sim 1.5 \mathrm{~m}$ deep. Then values oscillate between 1010 and $1015 \mathrm{~kg} / \mathrm{m}^{3}$ approximately, in a water layer between 2 and $3 \mathrm{~m}$ deep. The bottom layer averages values of 1022 $\mathrm{kg} / \mathrm{m}^{3}$ (figure 3).

\section{Second campaign}

The salinity data for the six transects carried out, in a general way, suggest that the Gulf of Urabá in the central zone could be divided into three layers (Figure 4a). The first layer, superficial, with depth of $\sim 2 \mathrm{~m}$, with values between 0 and 16 ups; the second layer, intermediate, with depth of $\sim 4 \mathrm{~m}$, with values from 20 to 30 ups; and the third layer, with an average salinity of 36 ups. Similarly, the temperature can be represented in three layers (Figure 4c). The first one is superficial, with depth close to $4 \mathrm{~m}$, with values between 27 and $28.5^{\circ} \mathrm{C}$. The second is intermediate with an average depth of $9 \mathrm{~m}$, and values between 29 and $31^{\circ} \mathrm{C}$. The third layer is deep, with a temperature between 28.5 and $30^{\circ} \mathrm{C}$. In the same way, the data can be represented in three layers (figure $4 \mathrm{~b})$. The surface with a depth of $\sim 2 \mathrm{~m}$, values between 1007 and $1012 \mathrm{~kg} / \mathrm{m} 3$. The second, at a depth of approximately $4 \mathrm{~m}$, with values between 1012 and $1020 \mathrm{~kg} / \mathrm{m} 3$. The third and last layer, with an average density of 1022 $\mathrm{kg} / \mathrm{m} 3$. The previous results suggest that the water density in the center of the Gulf of Urabá behaves similarlly to the distribution of its salinity.

\section{Conclusions}

The Gulf of Urabá central zone shows a typical structure of a saline wedge estuary constituted by 3 layers. The first one between 0 and $2 \mathrm{~m}$ deep corresponds to a mass of fresh water from the Atrato River (and some tributaries from the east side). Between 2 and $5 \mathrm{~m}$ lay the pycnocline and halocline. In the third layer, below an average of $6 \mathrm{~m}$, are the oceanic waters from the Caribbean Sea evidenced by its high salinity values (> 34 UPS). 


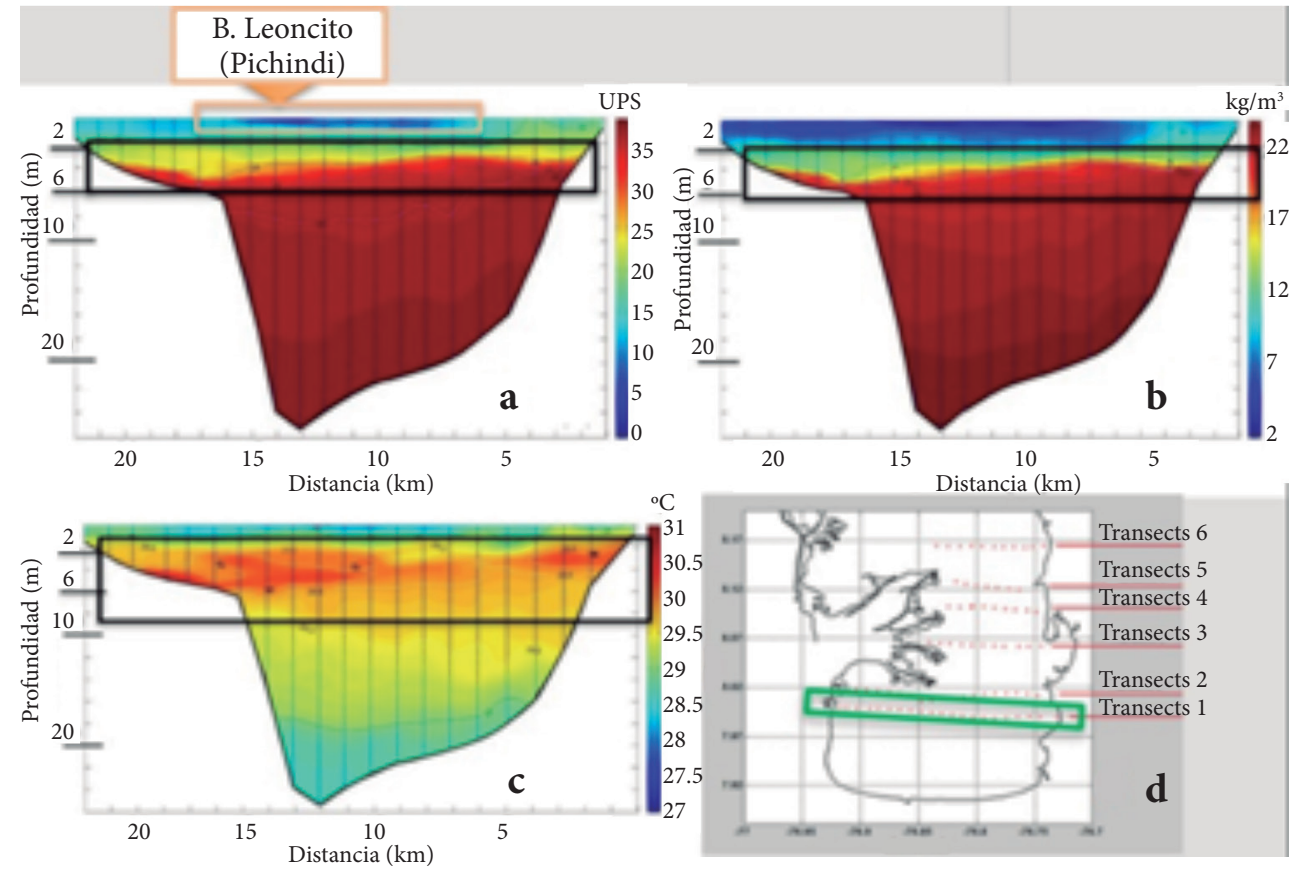

Figure 4. a) Contour plot of the salinity (UPS) in campaign 2, transect 1 . The transect counts with the mouth of the Atrato River (boca Leoncito), the bar of colours represents saline values, minimum 0 UPS (blue) and maximum 35 uPs (red). b) Contour plot of density $\left(\mathrm{kg} / \mathrm{m}^{3}\right)$ by campaign, transect 1 . The bar of colours represents the anomaly values of density (density- $\left.1000 \mathrm{~kg} / \mathrm{m}^{3}\right), \mathrm{minimum} 1002 \mathrm{~kg} /$ $\mathrm{m}^{3}$ (blue) and maximum $1022 \mathrm{~kg} / \mathrm{m}^{3}$ (red). c) Contour plot of temperature (Celsius degrees) by campaign, transect 1 . The bar of colours represents the values of temperature, minimum $27^{\circ} \mathrm{C}$ (blue) and maximum $31^{\circ} \mathrm{C}$ (red). d) Campaign 2 transect 1 . The rectangle of green colour, indicates transect 1 , each point of red colour indicates a launch of CTD.

\section{Acknowledgements}

To the Universidad Autónoma de Baja California (Mexico), Universidad de Antioquia and the Colombian National Navy (DIMAR), for providing all the logistic support to carry out the oceanographic campaigns.

\section{References}

P. R. Pinet. Invitation to oceanography. United States of America: Jones and Bartlett, 2003. 


\title{
ICT and its Incidence in the Productive Innovation of Renewable Energies
}

\author{
Dario J. Quiroga-Parra*, Ramón F. Colmenares-Quintero*, Gina Maestre-Góngora*
}

Universidad Cooperativa de Colombia, Colombia

E-mail:

dario.quirogap@campusucc.edu.co

\section{Introduction}

The current economy knowledge has been characterized by the impact of information and communication technologies (ICTS) on industry, the growth of services and innovation, and the accelerated development of renewable energies [1]. Moreover, ICTs have a high incidence on other technologies [2] and on other productive sectors. At the same time, the growth of global manufacturing productivity has aroused high levels of pollution, climate change, loss of natural habitats, diversity and shortage due to water scarcity. In fact, global economic growth has increased energy consumption, and with this, emerging countries have had to deal with a lack of energy efficiency and make use of renewable energy, where ICTS might help to contribute to mitigate problems and improve efficiency through technologically and environmentally sustainable economic models [3].

Renewable energies make use of natural resources such as water from rivers and seas, sunlight, thermal heat and wind, which engineering is willing and capable to transform into new useful energy [1]. The potential of these energies is relevant all over the world and it has provoked a strong interest of researchers from many different contexts in terms of its generation process, distribution, management and application [4].

Per se, energy has the capacity to do work and can't either be created or destroyed, but it can be transformed. In general, energy can be obtained from renewable or non-renewable sources. The most common non-renewable energy sources are fossil fuels such as coal, natural gas, uranium and oil. Renewable energies come from sources such as the sun, water and wind, which can't be manipulated at source. The solar energy is the main source of renewable energy [5].

On the other hand, when ICTs are present in productive processes improving energy efficiency and productivity, knowledge management is indisputably present and therefore the existence of an economy based on the use of knowledge is made evident [6]. Since the 1970s, industrial manufacturing processes with the help of ICTs, have been migrating towards services or are being complemented by them, modifying the sector's structure and streamlining information and communication processes [7]. Likewise, renewable energetic processes in developed countries are known to have an increased efficiency in the hand of ICTs [5, 8-9]. 
ICTs have multiple characteristics that contribute to previous processes, such as ubiquity, the condition of being a non-rival good, low costs, the ability to digitize in order to build a global digital network, which makes this a transverse technology with high potential for improving productive efficiency.

This study pretends to make a theoretical assessment of the relationship between the use of ICTs and their application in renewable energies. The methodology used was based on an international bibliographic compilation and the organization, processing and empirical analysis of statistical data from international databases. The document concludes by highlighting the importance of the two emerging technologies: ICTs and renewable energies, pointing out their strong theoretical and empirical relationships, ICTs impact, and the efficiency and productivity of renewable energies.

\section{Experimental}

This work included three main elements: ICTs, renewable energy, and efficiency and productivity. These were studied theoretically and empirically in and independent manner in order to analyse their particular characteristics. Subsequently, they were analysed as a whole to observe their final behaviour. The first step consisted of a bibliographic review through different international sources and journals such as Tailor,
Elsevier, Francis and Springer, and databases such as Scopus, Science direct and Google scholar. The next step covered the compilation of statistical data from international sources, plus an analysis and a theoreticalempirical correlation between the two technologies studied in energy efficiency and productivity processes.

\section{Results and Discussion}

After the appearance of the steam engine and the combustion engine during the first and second industrial revolution, the use of fossil fuels boomed. However, the fuel crisis of the last decades has shown the general need to implement renewable energies in order to satisfy the demand of global energy and preserve life in our planet.

Table 1 shows the 2016 Colombian panorama. It evidences that Colombia has a high level of access to electricity, compared to the average in Latin America (LA) and the world. However, per capita consumption is lower than the rest, this behaviour also applies to the fossil fuels consumption, which was also slightly lower. Today, the consumption of renewable energies is lightly lower than in LA but higher than the world's average. The production of renewable electricity in Colombia is higher than in LA and the rest of the world. This is a remarkable progress from which it is possible to infer a potential for exporting and efficiency in the use of natural resources.

Table 1. Access and energy consumption data in Colombia, Latin America and the World 2015-2016

\begin{tabular}{|l|c|c|c|c|c|c|}
\hline \multirow{2}{*}{ Concept } & \multicolumn{2}{c|}{ Colombia } & \multicolumn{2}{c|}{ Latin America } & \multicolumn{2}{c|}{ World } \\
\cline { 2 - 7 } & 2015 & 2016 & 2015 & 2016 & 2015 & 2016 \\
\hline Access to electricity (\% of population) & 98.18 & 99 & 97.25 & 97.79 & 87.05 & 87.37 \\
\hline Electric power consumption (kWh per capita) & 1287.2 & 1289.56 & 2124.74 & 2128.81 & 3105.97 & 3127.36 \\
\hline Energy consumption of fossil fuels (\% of total consumption) & 76.76 & 76.68 & 73.51 & 87.67 & 80.8 & 80.04 \\
\hline Consumption of renewable energy (\% of total consumption) & 24.44 & 23.56 & 27.08 & 27.6 & 17.87 & 18.05 \\
\hline Alternative nuclear energy (\% of total use) & 12.61 & 12.58 & 9.32 & 5.38 & 8.89 & 14.07 \\
\hline Production of renewable electric power (\% of total) & 74.04 & 68.23 & 53.1 & 51.7 & 22.4 & 22.85 \\
\hline
\end{tabular}

Source: $[10]$ 
Table 2. Data on use and access to ICT in Latin America and Colombia, 2015-2016

\begin{tabular}{|l|c|c|c|c|}
\hline \multirow{2}{*}{\multicolumn{1}{c|}{ Concept }} & Colombia & Colombia & Latin America & Latin America \\
\cline { 2 - 5 } & 2015 & 2016 & 2015 & 2016 \\
\hline Cell phones / 100 inhabitants & 116 & 117 & 113 & 113 \\
\hline Use of Internet with broadband / 100 inhabitants & 11.16 & 11.8 & 8.69 & 5.39 \\
\hline Secure servers & 57.3 & 60.2 & 52.5 & 54.1 \\
\hline Bit broadband per capita & 12.78 & 13.37 & 14.44 & 89.7 \\
\hline Mobile network coverage & 93 & 94 & 89 & 89 \\
\hline Computers / 100 inhabitants & 67 & 75 & 42 & 45 \\
\hline ICT expenditure per capita & 448 & 469 & 379 & 402 \\
\hline
\end{tabular}

Source: [10]

In terms of ICTs access and use, Colombia and LA show strengths in the use and coverage of cell phones. Nevertheless, there are flaws in the use of Internet with broadband, computers and secure servers (see table 2).

\section{Conclusions}

The emerging ICT technologies point out a strong relationship and impact on renewable energies, in terms of efficiency and productivity in all the international studies considered. In addition, renewable energies and ICTs have a high potential for development. There is an important theoretical and empirical relationship between the use of ICT and the use, application and productive efficiency of renewable energies.

\section{Acknowledgments}

This research work was funded by the "Identification of Knowledge Gaps in the Academia and Capacity" project \# IAPP1 $\backslash 100166$, Royal Academy of Engineering. Newton Fund, and cost European Cooperation in Science and Technology.

\section{References}

J.W. Houghton, HCC9/CIP, IFIP AICT 328 (2010).

E. Spiliotis, V. Marinakis, H. Doukas and J. Psarras, "Integrating a decision support system with smart grid infrastructures and ICT solutions towards energy cost reduction: An action plan to optimally schedule the operation of heating and electricity systems," in 2016 7th International Conference on Information, Intelligence, Systems \& Applications (IISA), Chalkidiki, 2016, pp. 1-6.

R. Youngman. (2012) “ICT Solutions for Energy Efficiency." In World Bank, Washington, DC. World Bank. Available: https://openknowledge.worldbank.org/handle/10986/12685F.

F. Ahmed, M. Naeem, M. Iqbal, Telecommun Syst Spinger, Springer Science Business Media New York (2016).

M.S. Hossain, N.A. Madlool, N.A. Rahim, J. Selvaraj, A.K. Pandey. Renewable and Sustainable Energy Reviews 60 1168 (2016).

D. Jorgenson, M. Ho, and J. Samuels, Policy, 40398 (2016).

K. Vu, M. Khuong, Policy, 41 (2017).

I. Zelenika and M. Pearce, Information Development, 29217 (2012).

F. Ahmed, M. Naeem and M. Iqbal, Telecommunication Systems, 6443 (2016). 


\title{
Trends of Microgrid as an Architecture for the Modernisation of Energy Use
}

\author{
Julián A. Mera Paz ${ }^{\star}$, Ramón F. Colmenares-Quintero*, Gina Maestre-Góngora*
}

Universidad Cooperativa de Colombia, Colombia

E-mail:

julian.mera@campusucc.edu.co

\section{Introduction}

Energy generation and use supposes a current worldwide concern. Today, countries around the world are developing projects to modernize the energy generation and distribution systems by adapting and creating architectures with a greater use of alternative energy sources, and offering a faster response to incidents or failures. These alternatives are of particular interest for municipalities or rural areas where public companies do not provide electricity services, forming the so-called non-interconnected zones (ZNI).

The microgrid concept approaches the controlled use of energy through the incorporation of renewable sources, with a high degree of autonomy, monitoring and control supported by information technology to optimize the transfer of energy, guaranteeing minimum risks and increasing quality, efficiency and reliability for energy generation, control and exchange. The microgrids are functionally a unique controlled system that can respond to the needs of energy transmission or transfer. A mapping study identifies and analyses the trends of the microgrid as architecture for modernizing energy use [1].

\section{Experimental}

The methodological approach is guided by a systematic literature mapping, characterized by the categorization, selection of scientific, and research documents, that develop topics on microgrid as architecture for modern energy use. Literature mapping went from 2015 to 2018, and were compiled using the Science Direct, Dialnet, Scopus, Springer, Engineering Village databases, as well as the spss software, as a quantitative tool for statistical trend analysis. The analysed information allowed a discussion around the incidences and challenges for each different architecture in terms of their control, strengths and improvement opportunities with the aim of identifying stable, efficient architectures with low risk index. 


\section{Results and Discussion}

The current climate change conditions, the greenhouse effect and other factors linked to the production of electric energy by sources such as coal, gas, oil and its derivatives, have made renewable energies a very good energetic alternative, especially when aided by the implementation of microgrids for their monitoring and control.

The SGAM (Smart Grid Architecture Model) used in a neutral scenario, allows the analysis of intelligent networks. SGAM provides a channel for the transition from electric power networks to renewable energy networks [2] and configures the levels of domain, zone and interoperability involved in the management of the electric power system [3].

Architecture SMG (Smart Micro Grid) is based on the supply of the energy service through digital components supported in a monitored and controlled system that transfers electric energy from the generation sources with the goal of minimizing environmental impact [4].

AMI (Advanced Measurement Infrastructure) integrates smart portable architectures with a smart meter. Its objective is to administrate applications that contribute to the efficient use of energy, guaranteeing high reliability in energy communication and transport [5].

Architecture ADAs (Advanced Automation of the distribution network) main's objective is the distribution system of electric power in an applicable, reliable, flexible, sustainable and efficient manner [6]

Architecture DERs (Distributed Energy Resources) main functions are the formulation of a microgeneration system with connection and control of alternating (AC) and continuous (DC) current, and a system for electrical energy storage [7].

With this information, the architectures of the microgrid for the modernized use of energy are analysed, consolidating 620 scientific products. The analysis is shown in table 1 with ADA and DER as the research trend.
Table 1. Trends in the architecture of scientific products

\begin{tabular}{|l|c|c|c|c|c|}
\hline \multirow{2}{*}{ Architecture } & \multicolumn{4}{|c|}{ Year } & \multirow{2}{*}{ Total } \\
\cline { 2 - 5 } & $\mathbf{2 0 1 5}$ & $\mathbf{2 0 1 6}$ & $\mathbf{2 0 1 7}$ & $\mathbf{2 0 1 8}$ & \\
\hline ADA & 0 & 21 & 168 & 58 & $\mathbf{2 4 7}$ \\
\hline AMI & 13 & 7 & 2 & 0 & $\mathbf{2 2}$ \\
\hline DER & 2 & 24 & 206 & 75 & $\mathbf{3 0 7}$ \\
\hline SGAM & 3 & 12 & 8 & 2 & $\mathbf{2 5}$ \\
\hline SMG & 3 & 8 & 6 & 2 & $\mathbf{1 9}$ \\
\hline Total & $\mathbf{2 1}$ & $\mathbf{7 2}$ & $\mathbf{3 9 0}$ & $\mathbf{1 3 7}$ & $\mathbf{6 2 0}$ \\
\hline
\end{tabular}

\section{Conclusions}

By mapping the study of microgrid trends as an architecture for the modernization of the use of energy, the strengths and opportunities for improvement in architectures are studied and analysed. ADA and DER architectures are statistically the most used in today's micro networks. However, it is evident that they present complements or additional systems based on software developments and/or applications that achieve a better performance, reliability, flexibility, monitoring and control of energy transfer. These analysis will be done in the future through a simulation using a commercial software that allows the design of microgrid architectures and the enhancement of their capacities.

\section{Acknowledgements}

The authors thank the project "Identification of Knowledge Gaps in the Academy and Capacity Building for Aquatic Renewable Energy in Colombia" led by the Universidad Cooperativa de Colombia, with resources from the Newton Fund of the United Kingdom, Heriot Watt University, Cotecmar and Aquatera. 


\section{References}

L. Mariam, M. Basu and M. F. Conlon. Renewable and Sustainable Energy Reviews, 64, 477 (2016).

CEN-CENELeC-etsi. (2014). Smart Grid Coordination Group. SG-CG/M490/K_SGAM usage and examples. [Online] Avai-

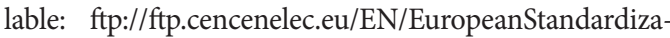
tion/HotTopics/SmartGrids/SGCG_Methodology_ SGAMUserManual.pdf.

W. M. Giral-Ramírez, H. J. Celedón-Flórez, E. GalvisRestrepo and A. T. Zona-Ortiz. Tecnura, 21119 (2017).

Y. S. Yoo, J. S. Lee, I. Lee and J. K. Choi. "Energy optimal management for prioritized distribution in smart grid." In Information and Communication Technology
Convergence (ICTC), 2016 International Conference, 2016, pp. 800-803.

S. Xu, Y. Qian and R. Hu. "A study on communication network reliability for advanced metering infrastructure in smart grid." In Dependable, Autonomic and Secure Computing, 15th Intl Conf on Pervasive Intelligence \& Computing, 3rd Intl Conf on Big Data Intelligence and Computing and Cyber Science and Technology Congress (DASC/PiCom/ DataCom/CyberSciTech), 2017, pp. 127-132.

M. H. Bollen, R. Das, S. Djokic P. Ciufo, J. Meyer, S. K. Rönnberg and F. Zavodam. IEEE Transactions on Smart Grid, 8391 (2017).

M. Marzband, N. Parhizi, M. Savaghebi and J. M. Guerrero. IEEE Transactions on Energy Conversion, 31637 (2016). 


\title{
Technological Strategy for the Installation of an Energy Solution for the Catatumbo Region
}

\author{
Alfredo Bohórquez ${ }^{\star}$, Torcoroma Velázques ${ }^{\star}$, Hugo F. Castro*
}

Universidad Francisco de Paula Santander, Ocaña, Colombia E-mail:

abohorquezni@ufpso.edu.co

\section{Introduction}

Starting from an energetic solution using a Pelton type micro turbine [1], an intelligent application based on semantic web is being developed; the system's design, construction and start-up phases are ontologically represented. This application would have an initial prototype in the Catatumbo region.

\section{Experimental}

The design of the micro turbine includes the application of three impellers of different diameters. The Pelton impeller is used in places of high altitude and little water flow. In this case, the power in kilowatts can be obtained with an equation given by the Manual of Mini and Micro Hydraulic Power Plants of the ITDG of Peru, published in 1995. The construction of the micro turbine is made with the sand moulding method. Knowledge representation is based on the principles of descriptive logic, the tasks proposed are developed and the protégé tool is used [2]. 


\section{Results and Discussion}

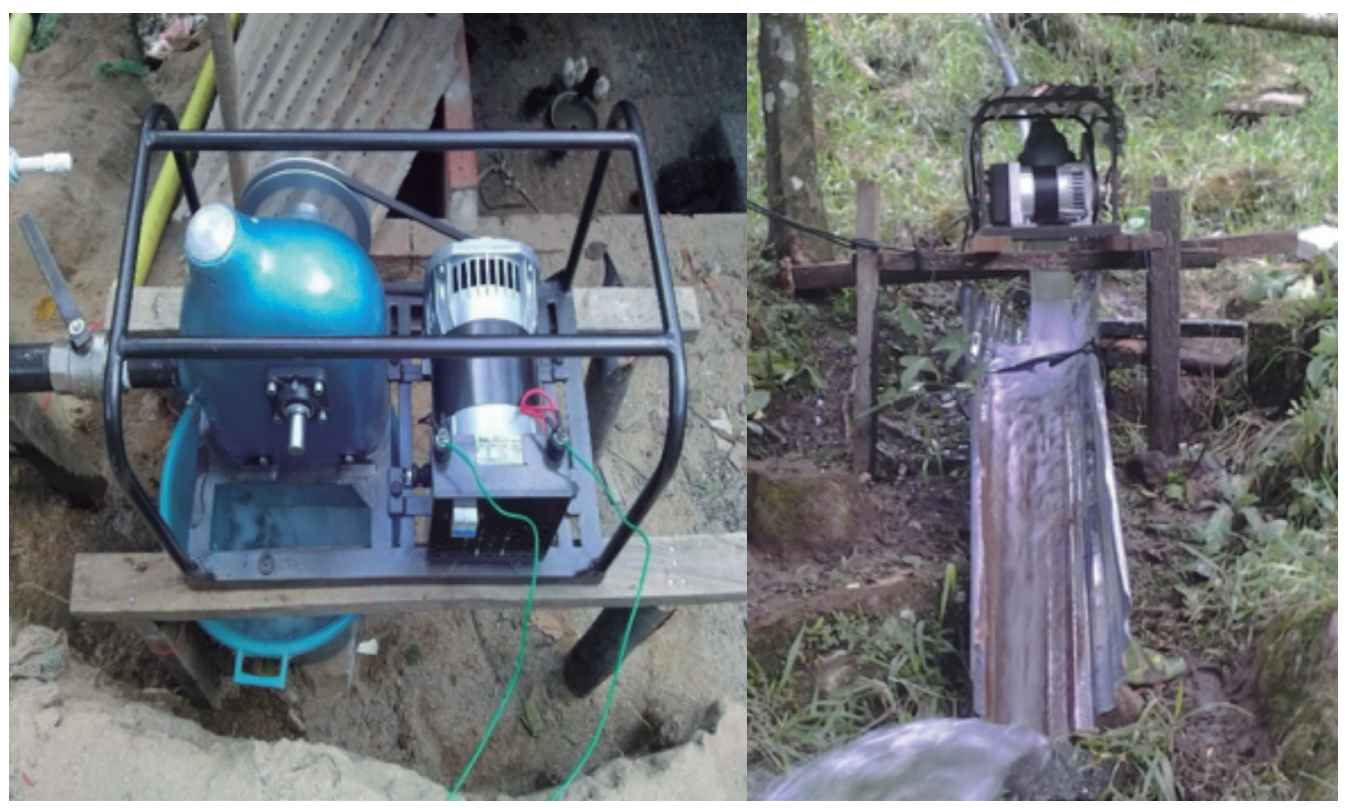

Figure 1. Images of the energy solution
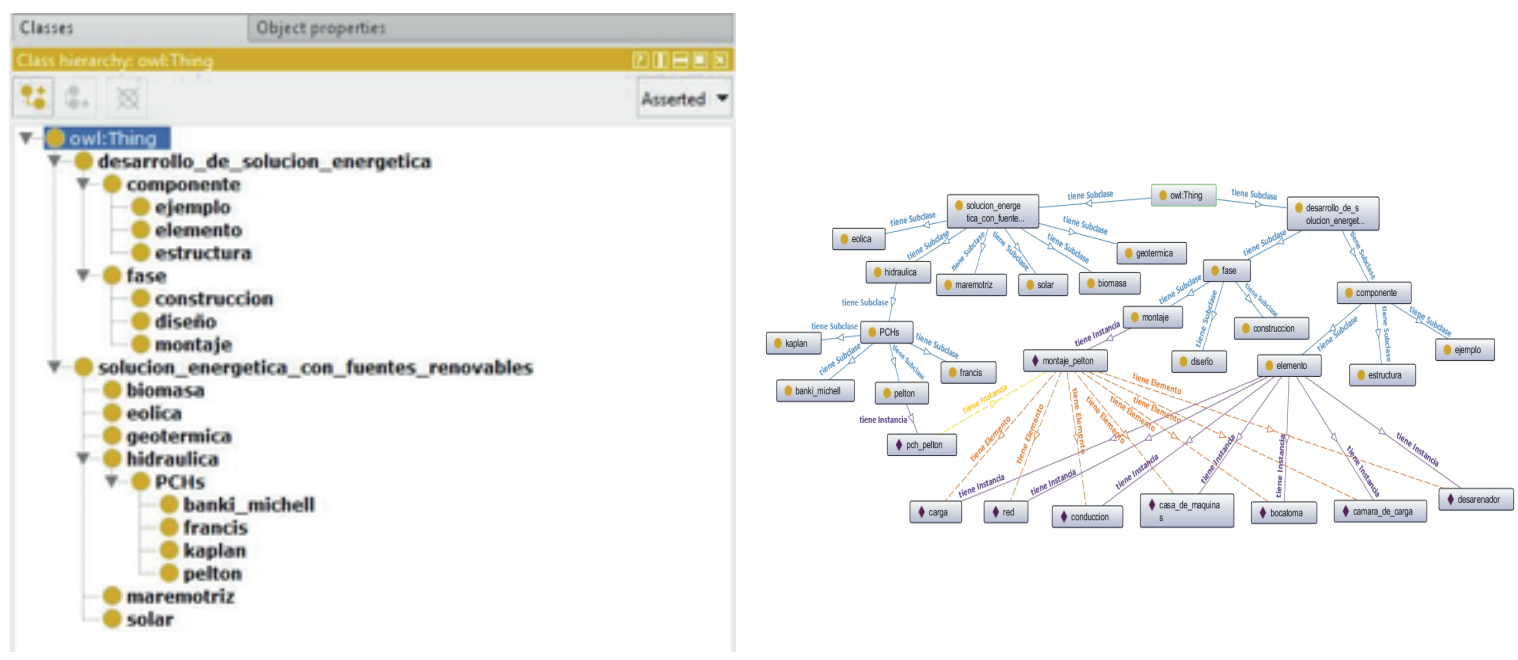

Figure 2. Ontological representation of the technological strategy 


\section{Conclusions}

The semantic web is an extension of the current web endowed with meaning. It is possible to represent the specification of the concept of the energy solution for the interconnected areas with the phases of conceptualization, formalization and construction of the ontological system. With the support of the methontology, the different phases for the construction of the concepts' taxonomy, with their respective instances and relationships are carried out.

\section{Acknowledgements}

An acknowledgement for Didier Gaona of GITYD group.

\section{References}

B. Niño, Revista Colombiana de Tecnologías de Avanzada, 131 (2018).

T. V. Pérez, A. M. P. Velásquez, J. A. G. Luna. Avances en Sistemas e Informática, (2011). 


\section{Renewable Energy Actions in the Coffee Region of Caicedonia - Valle del Cauca Department}

Jhon E. Cerón* ${ }^{* *}$

\footnotetext{
Corporación Universitaria Remington - SENA

Agroarte, Caicedonia, Valle del

Cauca, Colombia

E-mail:

electroceron@hotmail.com
}

\section{Introduction}

Energy companies are facing an increasing need to find newer environmentally friendly practices and at the same time, comply with the world's energetic demand. Today, fuel supply and the environment are in jeopardy due to the scarcity of fossil fuels and the use of methods that threaten the environment and of course, human existence. The exploitation of renewable energy resources may solve this need of sustainable energy supply. Among these resources, the sun is the cleanest and most abundant source of renewable energy available, and Colombia in particular possesses some of the richest solar resources in America. With this project, Agroarte seeks to provide energy and training to the rural population of the Caicedonia region in the Valle del Cauca department and its surroundings, exploiting its solar resources.

The work presented here is only the beginning of the project. It has the strategic desire to build a sustainable business that can be replicated throughout the Colombian rural territory and that motivates everyone to join this sustainable campaign.

Table 1. Renewable energy responsibility for environmental sustainability

\begin{tabular}{|l|l|}
\hline \multicolumn{1}{|c|}{ Renewable energy } & \multicolumn{1}{|c|}{ Environmental sustainability } \\
\hline $\begin{array}{l}\text { "A true energy revolution in Colombia will only be } \\
\text { achieved when comprehensive decisions are taken } \\
\text { that include the consequences of climate change, } \\
\text { but also involve the impact of energy sources on } \\
\text { health and poverty." }\end{array}$ & $\begin{array}{l}\text { Company with responsible ethics of its products, } \\
\text { with a comprehensive management for recovering } \\
\text { Carolina Urrutia (Semana magazine) }\end{array}$ \\
\hline
\end{tabular}

\section{General objective}

Formulate a project to generate electricity through the conversion of photovoltaic solar energy by the use of home kits. Provide teaching services in the use of renewable solar energy and explain how the population of Caicedonia (Valle del Cauca Department) can benefit from it. 


\section{Justification}

Caicedonia is located in the Colombian coffee producer region, with an approximate of 30,100 habitants. According to Invest Pacific, it is an attractive location for international investment. The project will have impact on the social, economic and environmental development of the region.

- Social impact: The project will generate more than 30 jobs and offer electricity to a community that lacks energy supply.

- Economic impact: Families will benefit from the free service of solar resources, hence saving money in energy spending.

- Environmental impact: The use of solar energy is a non-polluting, environmentally friendly practice.

\section{Problem validation and indicators}

The validation of the problem was conducted by applying a survey. The sample selected 56 rural and urban households in the region of Caicedonia, from a total of 312 households, and comprised families that complained due to the high costs of electrical energy consumption and that were affected by an electricity deficit in rural areas.

The training achievement indicators (training in types of renewable energies, accessories and installations) chosen were the following:

1. Total people trained by vereda (sub-divisional administrative part of a municipality in Colombia): 20

2. Total people trained in urban areas: 40

\section{Expected results}

Table 2. Financial operations for 2019

\begin{tabular}{|l|c|}
\hline Annual purchases (\$ COP) & $27,600.000$ \\
\hline Monthly sales (\$ COP) & $4,069,540$ \\
\hline Annual sales (\$ coP) & $48,834,480$ \\
\hline Net profit (\$ COP) & $6,841,029$ \\
\hline Profit margin (\%) & 7.32 \\
\hline
\end{tabular}

The company's income will come from the market of at least 60 kits and from the sale of teaching services. The previous study serves as our Minimum Viable Product (MVP) to stablish the feasibility of the business.

\section{Conclusions}

The project will generate a start-up for the commercialization of solar renewable energy and the provision of training and education services, which will have an impact on social, economic and environmental development of the Colombian coffee producing region.

\section{References}

Virtual News Centre. (2014). "Colombia a power in alternative energies." [Online] Available: http://www.mineducacion.gov.co/cvn/1665/article-117028.html

Anae Association (2010). "Energy Monitors." [Online] Available: http://www.asociacion-anae.org/tienda/ monitores-energeticos 
Training course 


\section{Training Course on Aerospace Propulsion, Power, and Energy}

Invited: Daniel Portnoy

Speaker: Consultech Colombia IL SAS E-mail:

yportnoy@inter.net.il
Objective: Introduce the attendees to basic concepts of aerospace engineering Number of Attendees: 30

\section{Contents:}

\section{Opening}

1. Why space? Reasons that justify the need for space development

2. The Space Race: How were the beginnings and ending of the space race between the U.S and Russia. What is the current situation?

3. Complete course on aerospace engineering: Program and syllabus

\section{Aerospace Propulsion}

1. Launch: Launching vector types for satellites LEO, MEO AND GEO

2. Basic concepts
a. Propulsion formula for rocket engines
b. Specific impulse
c. Liquid and solid propellants
d. Launch stages

3. Types of rocket engines for launch and space
a. Gas engines
b. Chemical engines: bipropellants and monopropellants, solid and hybrid propellants
c. Electrothermal engines
d. Electric engines: Ionic and Hall engines

4. Types of launching vectors: Dneper, Start, Pegasus, etc. 


\section{Summary:}

The training course took place the $20^{\text {th }}$ of September 2018 within the framework of the $1^{\text {st }}$ International Congress on Biorefineries and Renewable Energies
Supported by ICTs and lasted 3 hours. Attendees were mainly students and professors from the UCC Engineering Faculty, professors from other national universities, and high school students from different institutions in Medellín.

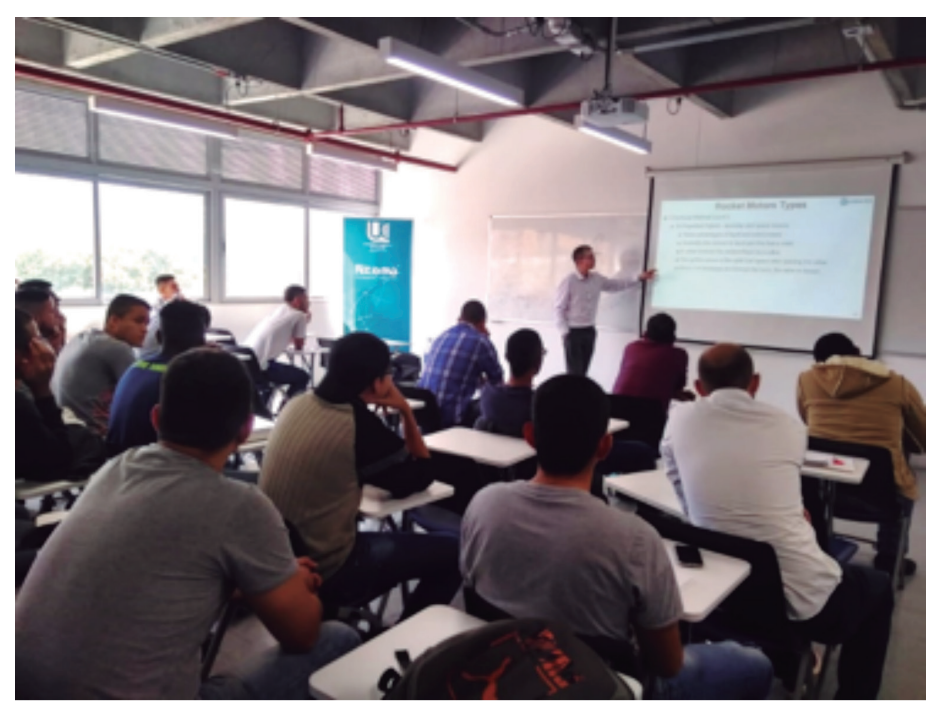


We would like to thank all participants and speakers for their attendance and participation. We hope this Congress was an opportunity for learning and cooperation. We look forward to see you all in the next version of the Congress. 

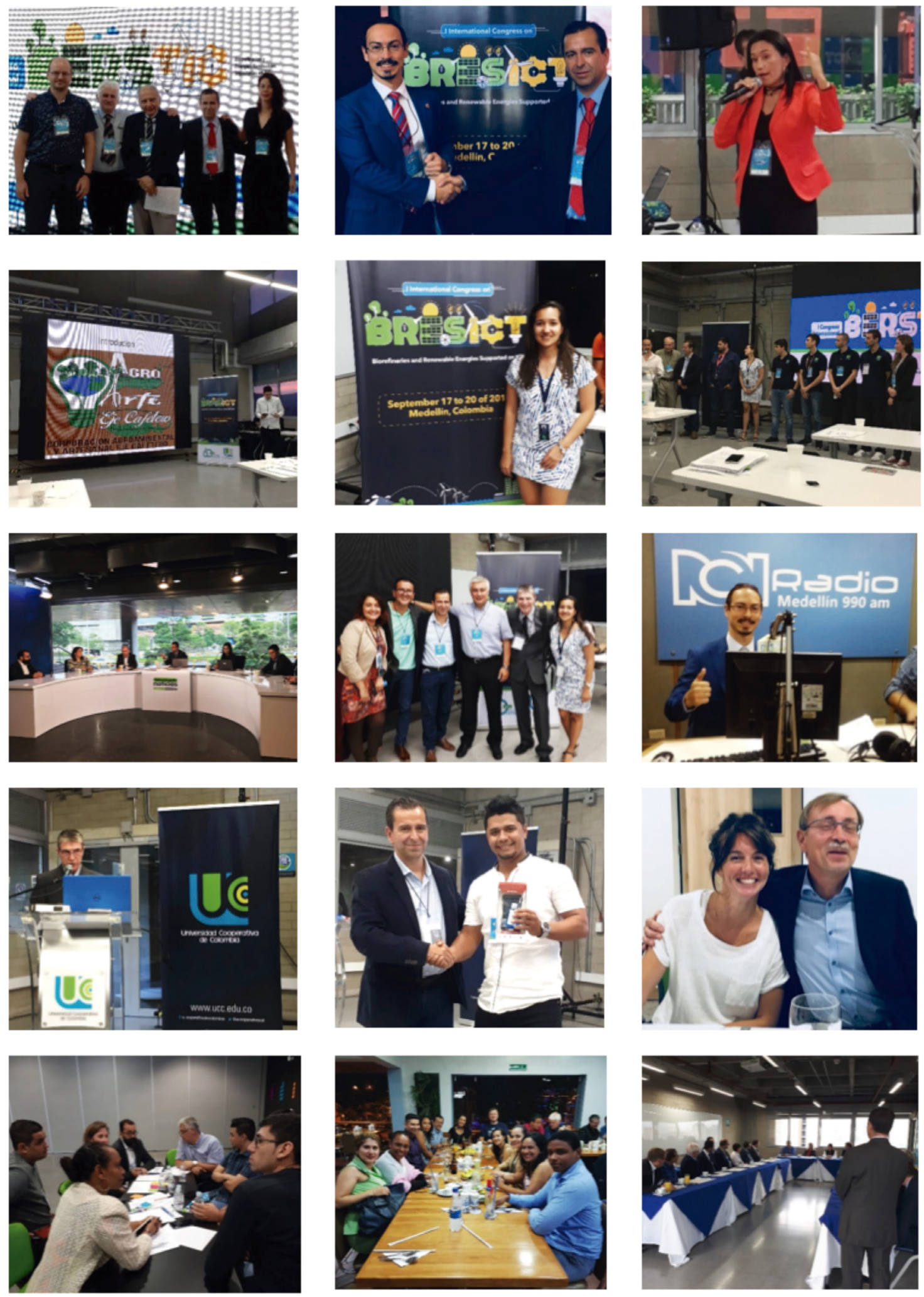


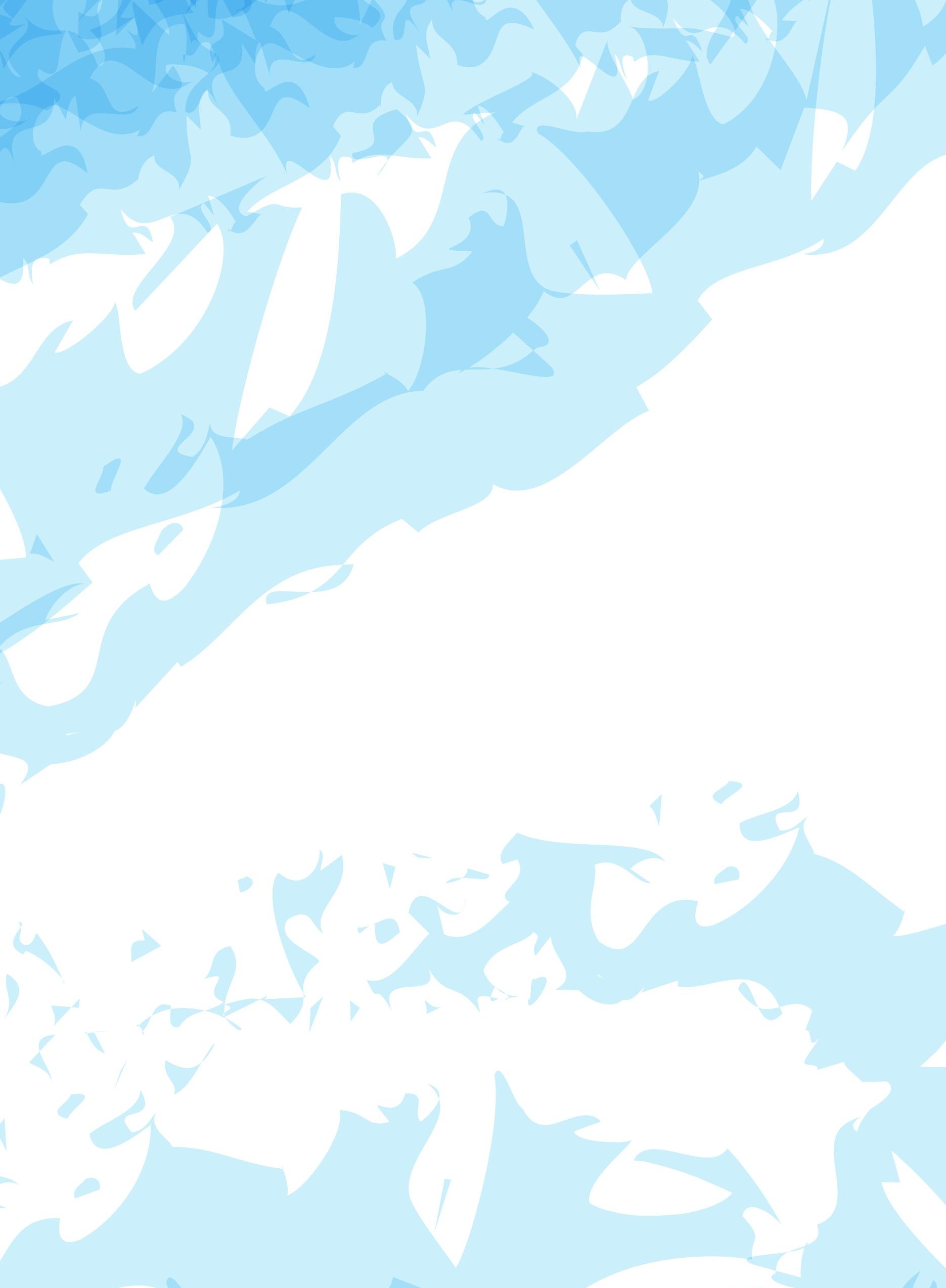

